Nevada

Environmental

Management

Operations Activity

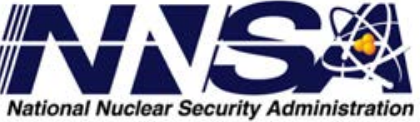

Corrective Action Investigation Plan for Corrective Action Unit 568:

Area 3 Plutonium Dispersion Sites

Nevada National Security Site,

Nevada

Controlled Copy No.:

Revision No.: 0

January 2014

UNCLASSIFIED

/s/ Joseph P. Johnston

Joseph P. Johnston, N-I CO

$01 / 27 / 2014$

Date

Approved for public release; further dissemination unlimited.

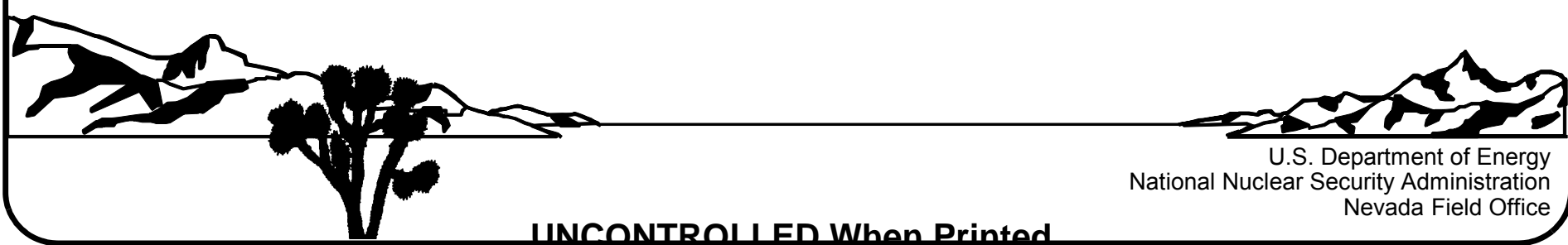


Available for sale to the public from:

U.S. Department of Commerce

National Technical Information Service

5301 Shawnee Road

Alexandria, VA 22312

Telephone: 800.553.6847

Fax: 703.605.6900

E-mail: orders@ntis.gov

Online Ordering: http://www.ntis.gov/help/ordermethods.aspx

Available electronically at http://www.osti.gov/bridge

Available for a processing fee to U.S. Department of Energy and its contractors, in paper, from:

U.S. Department of Energy

Office of Scientific and Technical Information

P.O. Box 62

Oak Ridge, TN 37831-0062

Phone: 865.576.8401

Fax: 865.576.5728

Email: reports@adonis.osti.gov

Reference herein to any specific commercial product, process, or service by trade name, trademark, manufacturer, or otherwise, does not necessarily constitute or imply its endorsement, recommendation, or favoring by the United States Government or any agency thereof or its contractors or subcontractors. 


\title{
CORRECTIVE ACTION INVESTIGATION PLAN FOR CORRECTIVE ACTION UNIT 568: AREA 3 PLUTONIUM DISPERSION SITES NEVADA NATIONAL SECURITY SITE, NEVADA
}

\author{
U.S. Department of Energy, National Nuclear Security Administration \\ Nevada Field Office \\ Las Vegas, Nevada
}

Controlled Copy No.:

Revision No.: 0

January 2014

Approved for public release; further dissemination unlimited. 


\section{CORRECTIVE ACTION INVESTIGATION PLAN \\ FOR CORRECTIVE ACTION UNIT 568: \\ AREA 3 PLUTONIUM DISPERSION SITES \\ NEVADA NATIONAL SECURITY SITE, NEVADA}

\begin{tabular}{l} 
Approved by: $\quad$ /s/ Tiffany A. Lantow \\
\cline { 2 - 2 } \\
$\begin{array}{l}\text { Tiffany A. Lantow } \\
\text { Soils Activity Lead }\end{array}$
\end{tabular}

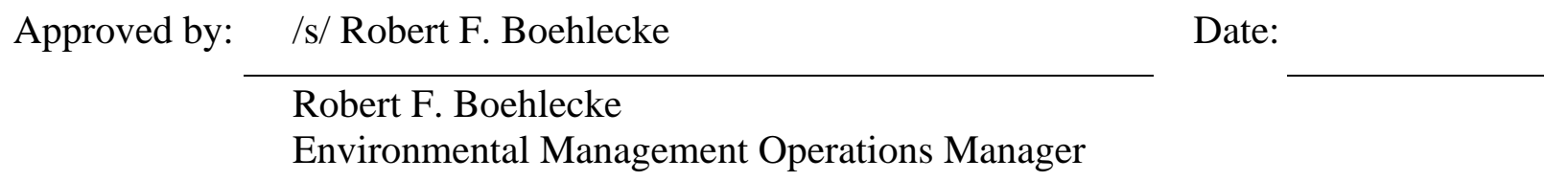




\section{Table of Contents}

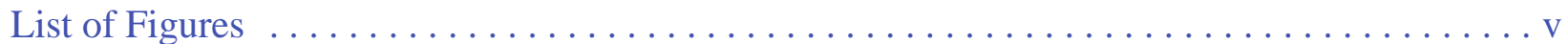

List of Tables ...................................... vi

List of Acronyms and Abbreviations $\ldots \ldots \ldots \ldots \ldots \ldots \ldots \ldots \ldots \ldots \ldots \ldots \ldots \ldots \ldots \ldots \ldots$

Executive Summary . . . . . . . . . . . . . . . . . . . . . . . . . . . . . ES-1

$1.0 \quad$ Introduction. . . . . . . . . . . . . . . . . . . . . . . . . . . 1

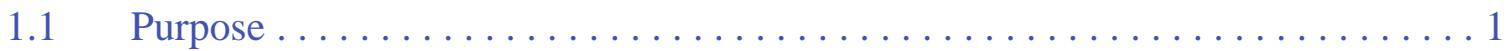

1.1.1 CAU 568 History and Description . . . . . . . . . . . . . . 1

1.1.2 Data Quality Objective Summary...................... 6

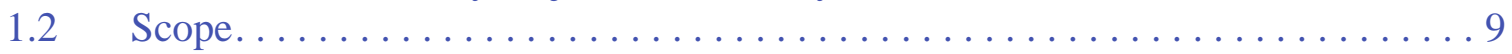

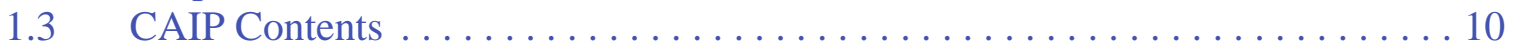

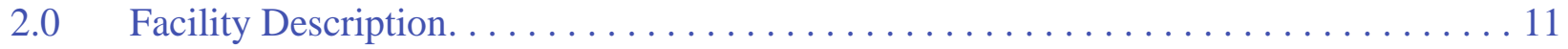

2.1 Physical Setting. . . . . . . . . . . . . . . . . . . . . . . 11

2.2 Operational History. . . . . . . . . . . . . . . . . . . . . . . . . 12

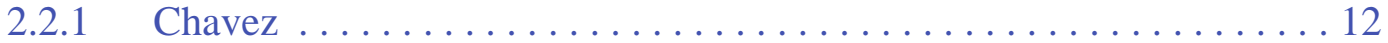

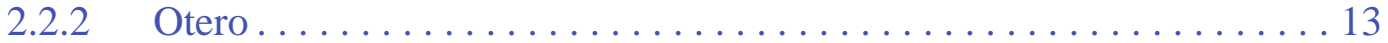

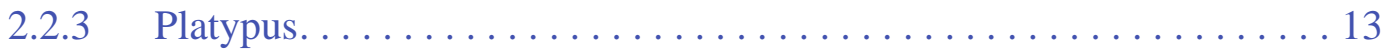

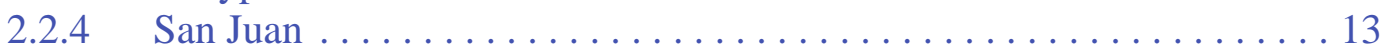

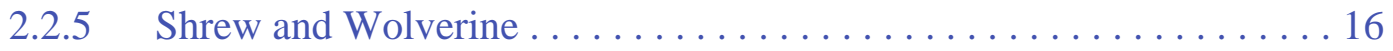

2.2.6 Additional Surface Releases from Underground Tests. . . . . . . . . . . . 16

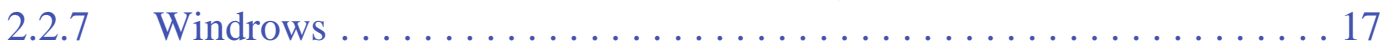

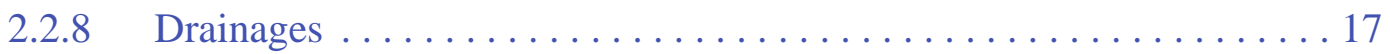

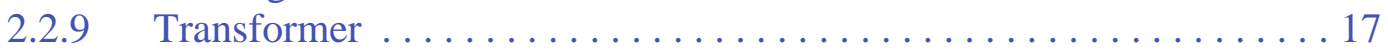

2.2 .10 Lead Items . . . . . . . . . . . . . . . . . . . . . . 18

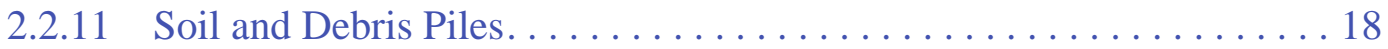

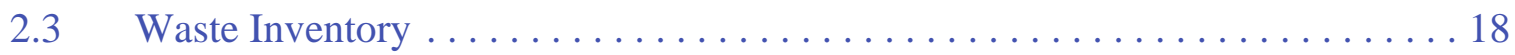

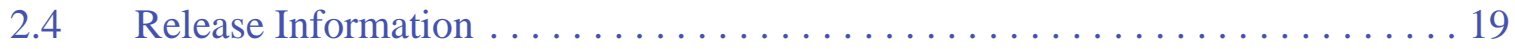

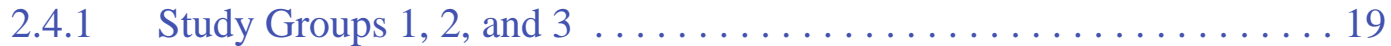

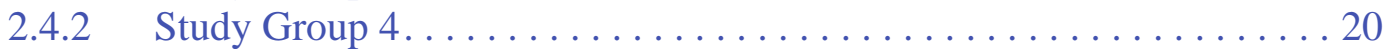

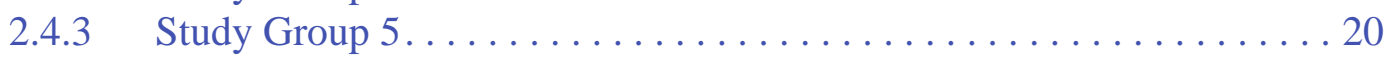

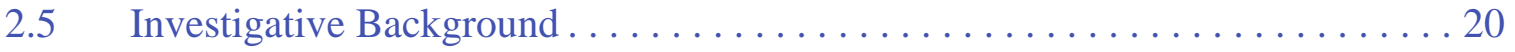

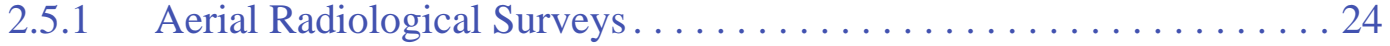

2.5 .2 RIDP and NAEG Data . . . . . . . . . . . . . . . . . 25

2.5.3 CAU 568 Preliminary Investigation . . . . . . . . . . . . . . 27

2.5.4 National Environmental Policy Act . . . . . . . . . . . . . 27

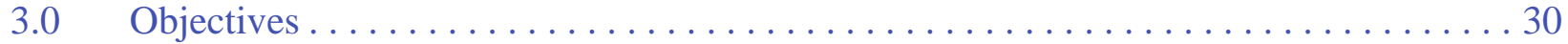

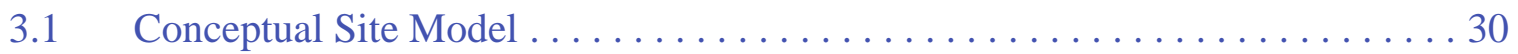

3.1.1 Land-Use and Exposure Scenarios . . . . . . . . . . . . . 30

3.1.2 Contaminant Sources . . . . . . . . . . . . . . . . . . . 32 


\section{Table of Contents (Continued)}

3.1.3 Release Mechanisms. . . . . . . . . . . . . . . . . . . 32

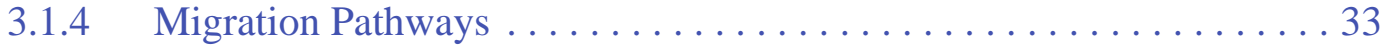

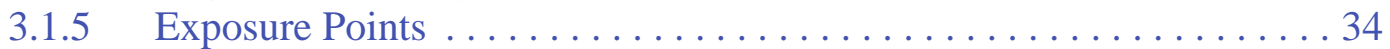

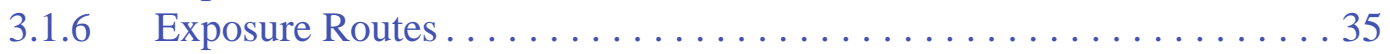

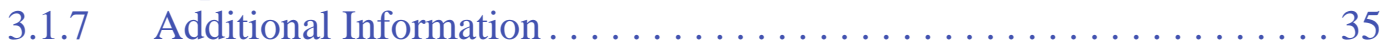

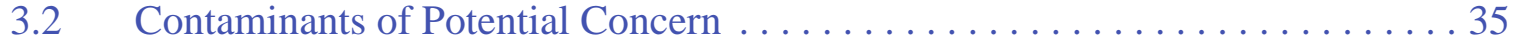

3.3 Preliminary Action Levels . . . . . . . . . . . . . . . . . . . 36

3.3.1 Chemical PALs.............................. 39

3.3.2 Radionuclide PALs............................. 39

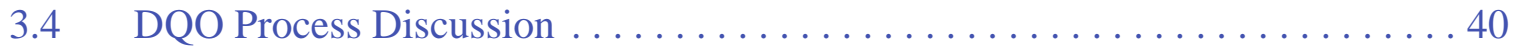

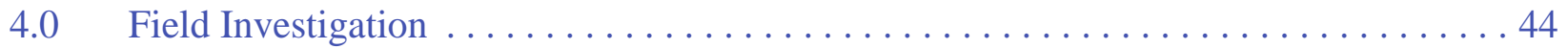

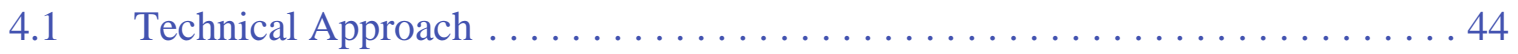

$4.2 \quad$ Field Activities . . . . . . . . . . . . . . . . . . . . . . . 45

4.2.1 Site Preparation Activities . . . . . . . . . . . . . . . . . 45

4.2 .2 Sample Location Selection . . . . . . . . . . . . . . . . 46

4.2.2.1 Study Group 1: Releases within a Defined

Radiological Survey Signature ...............46

4.2.2.2 Study Group 2: Releases Located within a Crater or Potential Crater Area That Cannot Be Entered . . . . . 47

4.2.2.3 Study Group 3: Releases with No Radiological Survey Signature That Can Be Entered . . . . . . . . . 47

4.2.2.4 Study Group 4: Spills and Debris . . . . . . . . . . . 48

4.2.2.5 Study Group 5: Drainages ................. 48

4.2 .3 Sample Collection. . . . . . . . . . . . . . . . . . . . 49

4.2 .4 Sample Management . . . . . . . . . . . . . . . . . . 50

$4.3 \quad$ Site Restoration. . . . . . . . . . . . . . . . . . . . . . 50

$5.0 \quad$ Waste Management. . . . . . . . . . . . . . . . . . . . . 52

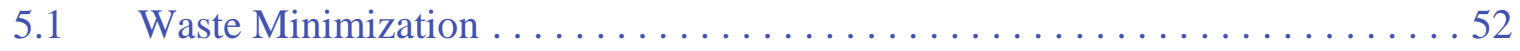

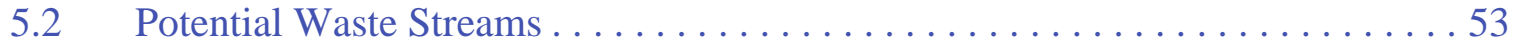

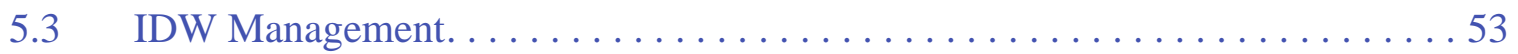

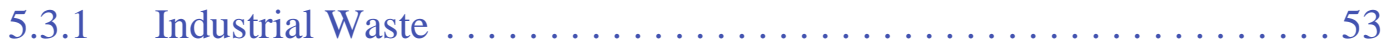

5.3 .2 Hazardous Waste . . . . . . . . . . . . . . . . . . . . 53

5.3 .3 Hydrocarbon Waste . . . . . . . . . . . . . . . . . . . . 54

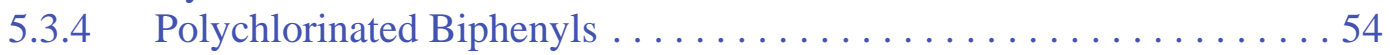

5.3 .5 Low-Level Waste . . . . . . . . . . . . . . . . . . . . . . 54

5.3.6 Mixed Low-Level Waste . . . . . . . . . . . . . . . . . 54

6.0 Quality Assurance/Quality Control . . . . . . . . . . . . . . . . . . 55

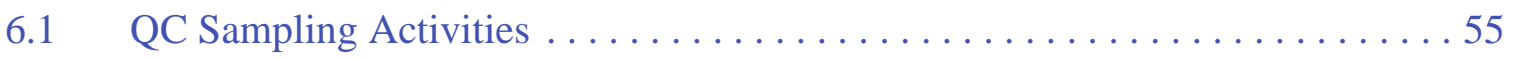




\section{Table of Contents (Continued)}

$6.2 \quad$ Laboratory/Analytical Quality Assurance $\ldots \ldots \ldots \ldots \ldots \ldots \ldots \ldots$

$7.0 \quad$ Duration and Records Availability . . . . . . . . . . . . . . . . . . 57

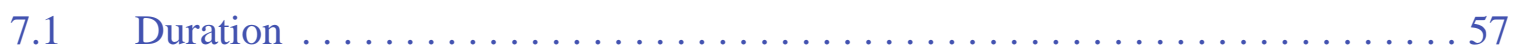

$7.2 \quad$ Records Availability ............................... 57

$8.0 \quad$ References........................................ 58

\section{Appendix A - Data Quality Objectives}

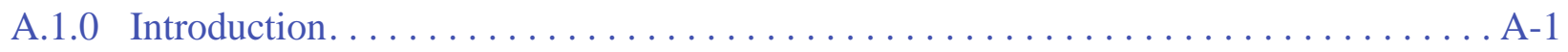

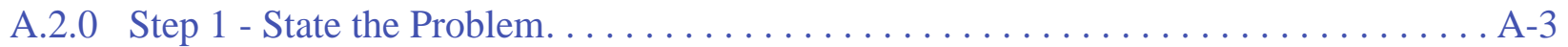

A.2.1 Planning Team Members $\ldots \ldots \ldots \ldots \ldots \ldots \ldots \ldots \ldots \ldots \ldots \ldots \ldots . \ldots \ldots$

A.2.2 Conceptual Site Model .............................. A-3

A.2.2.1 Release Sources ........................... A-4

A.2.2.2 Potential Contaminants........................ A-11

A.2.2.3 Contaminant Characteristics.................... A-12

A.2.2.4 Site Characteristics ........................ A-18

A.2.2.5 Migration Pathways and Transport Mechanisms ............ A-18

A.2.2.6 Exposure Scenarios. . . . . . . . . . . . . . . . . A-20

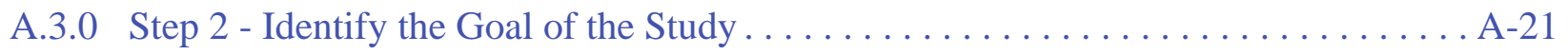

A.3.1 Decision Statements . . . . . . . . . . . . . . . . . . . . . . . A-21

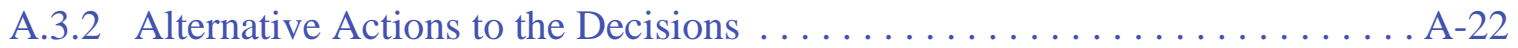

A.3.2.1 Alternative Actions to Decision I . . . . . . . . . . . . A-22

A.3.2.2 Alternative Actions to Decision II . . . . . . . . . . . . A-22

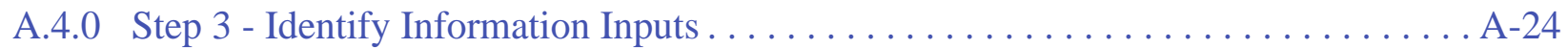

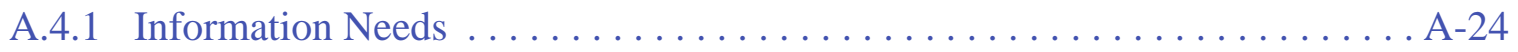

A.4.2 Sources of Information .............................. A-25

A.4.2.1 Sample Locations ........................... A-25

A.4.2.2 Analytical Methods......................... A-25

A.5.0 Step 4 - Define the Boundaries of the Study $\ldots \ldots \ldots \ldots \ldots \ldots \ldots \ldots \ldots$ A-26

A.5.1 Target Populations of Interest. . . . . . . . . . . . . . . . . . A-26

A.5.2 Spatial Boundaries ................................... A-26

A.5.3 Practical Constraints . . . . . . . . . . . . . . . . . . . . . . . . . A

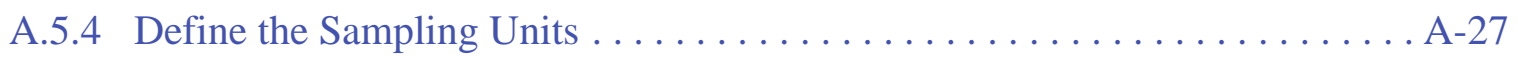

A.6.0 Step 5 - Develop the Analytic Approach ....................... A-28 


\section{Table of Contents (Continued)}

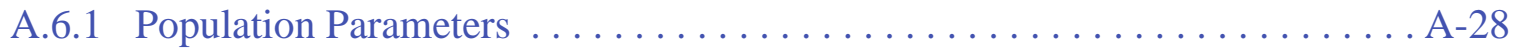

A.6.1.1 Judgmental Sampling Design ..................... A-28

A.6.1.2 Probabilistic Sampling Design . . . . . . . . . . . . . . . . . . . . . . A-28

A.6.2 Action Levels . . . . . . . . . . . . . . . . . . . . . . . . . . . . . . . . . . A-29

A.6.2.1 Chemical PALs........................... A-30

A.6.2.2 Radionuclide PALs.............................. A-30

A.6.3 Decision Rules . . . . . . . . . . . . . . . . . . . . . . . . . . . . . . . A-30

A.7.0 Step 6 - Specify Performance or Acceptance Criteria $\ldots \ldots \ldots \ldots \ldots \ldots \ldots$ A-32

A.7.1 Decision Hypotheses. . . . . . . . . . . . . . . . . . . . . . . . . . . A-32

A.7.2 False-Negative Decision Error . . . . . . . . . . . . . . . . . A-32

A.7.2.1 False-Negative Decision Error for Judgmental Sampling . . . . . . . . A-33

A.7.2.2 False-Negative Decision Error for Probabilistic Sampling . . . . . . . A-34

A.7.3 False-Positive Decision Error . . . . . . . . . . . . . . . . . . A-35

A.8.0 Step 7 - Develop the Plan for Obtaining Data $\ldots \ldots \ldots \ldots \ldots \ldots \ldots \ldots \ldots$ A-36

A.8.1 Study Group 1 (Releases within a Defined Radiological Signature) . . . . . . . A-36

A.8.1.1 Decision I Sample Selection...................... A-37

A.8.1.2 Decision II Sample Selection .................... A-37

A.8.1.3 Determination of Buried Contamination ............... A-37

A.8.2 Study Group 2 (Releases Located within a Crater or Potential

Crater Area That Cannot Be Entered)....................... A-41

A.8.3 Study Group 3 (Releases with no Radiological Signature) . . . . . . . . . . . . A-42

A.8.3.1 Decision I Sample Selection. . . . . . . . . . . . . . . . . A-42

A.8.3.2 Decision II Sample Selection . . . . . . . . . . . . . . A-42

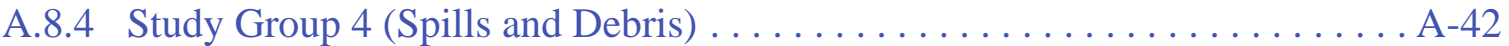

A.8.4.1 Decision I Sample Selection........................ A-43

A.8.4.2 Decision II Sample Selection . . . . . . . . . . . . . . A-43

A.8.5 Study Group 5 (Drainages) . . . . . . . . . . . . . . . . . . . . . . A A-45

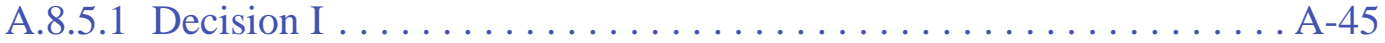

A.8.5.2 Decision II .............................. A-46

A.9.0 References. . . . . . . . . . . . . . . . . . . . . . . . . . . . . . . . . . . . . . A-47

\section{Appendix B - Activity Organization}

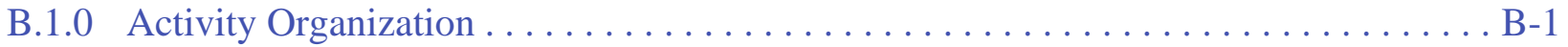

Appendix C - Nevada Division of Environmental Protection Comments 


\section{List of Figures}

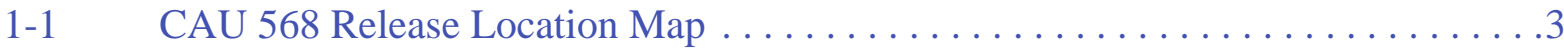

1-2 CAU 568 Release Location Map $\ldots \ldots \ldots \ldots \ldots \ldots \ldots \ldots \ldots \ldots \ldots \ldots \ldots \ldots \ldots \ldots \ldots \ldots$

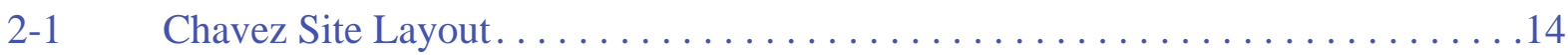

2-2 Otero, San Juan, Platypus, Shrew, and Wolverine Site Layout . . . . . . . . . . 15

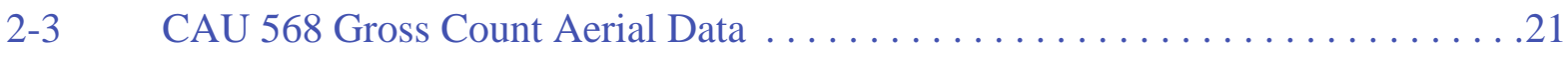

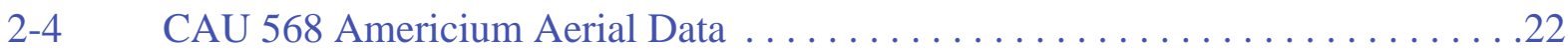

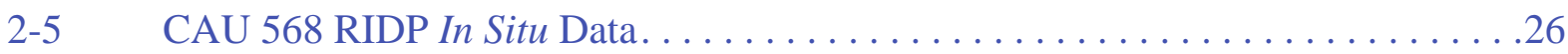

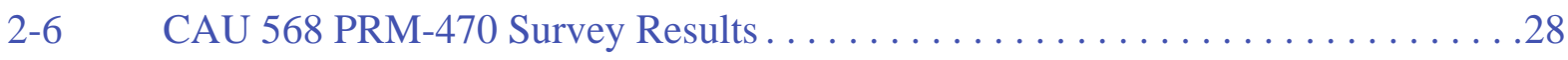

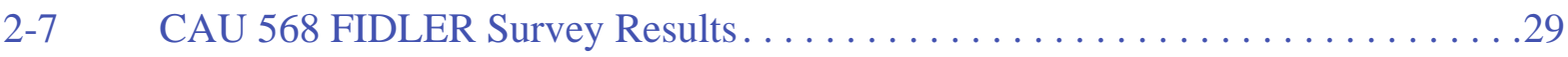

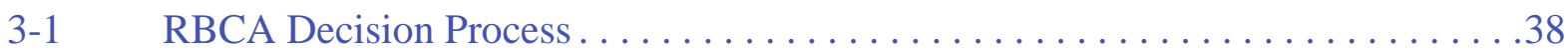

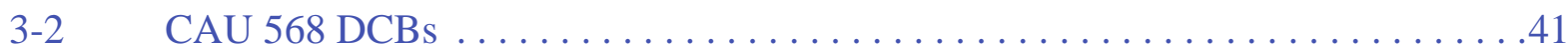

A.2-1 CAU 568 CSM Pathways to Receptors $\ldots \ldots \ldots \ldots \ldots \ldots \ldots \ldots \ldots$ A-8

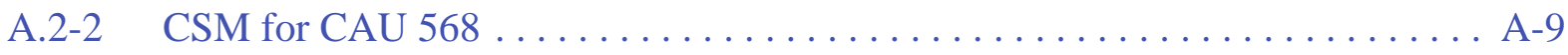

A.8-1 CAU 568 Sample Plot Locations for Study Group 1 (Otero and San Juan Release Area $\ldots \ldots \ldots \ldots \ldots \ldots \ldots \ldots \ldots \ldots \ldots \ldots \ldots \ldots \ldots \ldots$ A $\ldots \ldots \ldots$

A.8-2 CAU 568 Sample Plot Locations for Study Group 1 (Chavez

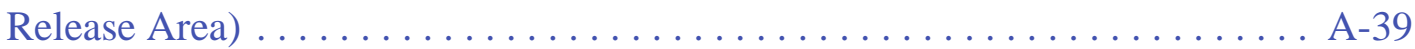

A.8-3 Sample Plot Sample Collection Layout . . . . . . . . . . . . . . . A-40

A.8-4 Study Group 4 PSM and Debris Locations................... A-44 


\section{List of Tables}

1-1 CAU 568 CASs and Associated Releases . . . . . . . . . . . . . . . . .4

2-1 Rainfall and PET Information for Yucca Flat. . . . . . . . . . . . . . . . . . . . . 12

2-2 Comparison of Radiation Survey Methods. . . . . . . . . . . . . . 23

A.2-1 CSM Description of Elements for Each Release in CAU $568 \ldots \ldots \ldots \ldots \ldots$. . . . 5

A.2-2 Contaminants of Potential Concern . . . . . . . . . . . . . . . . . . . A-13

A.2-3 Analyses Required by Group $\ldots \ldots \ldots \ldots \ldots \ldots \ldots \ldots \ldots \ldots \ldots \ldots \ldots \ldots$

A.2-4 Analytes Reported Per Method. . . . . . . . . . . . . . . . A-16

A.2-5 Vertical Migration Potential through the Vadose Zone of the Major Radionuclide Contaminants . . . . . . . . . . . . . . . . . . . . . . A-17

A.2-6 Land-Use and Exposure Scenarios . . . . . . . . . . . . . . . . A-20 


\section{List of Acronyms and Abbreviations}

Ac

Ag

$\mathrm{Al}$

Am

ASTM

bgs

BJY

CA

CAA

CAI

CAIP

CAS

CAU

CERCLA

CFR

$\mathrm{cm}$

$\mathrm{Cm}$

Co

COC

COPC

cpm

cps

Cs

CSM

DCB

DOE
Actinium

Silver

Aluminum

Americium

ASTM International

Below ground surface

Buster Jangle Y

Contamination area

Corrective action alternative

Corrective action investigation

Corrective action investigation plan

Corrective action site

Corrective action unit

Comprehensive Environmental Response, Compensation, and Liability Act

Code of Federal Regulations

Centimeter

Curium

Cobalt

Contaminant of concern

Contaminant of potential concern

Counts per minute

Counts per second

Cesium

Conceptual site model

Default contamination boundary

U.S. Department of Energy 


\section{List of Acronyms and Abbreviations (Continued)}

\begin{tabular}{ll} 
DQA & Data quality analysis \\
DQI & Data quality indicator \\
DQO & Data quality objective \\
EPA & U.S. Environmental Protection Agency \\
Eu & Europium \\
FAL & Final action level \\
FFACO & Federal Facility Agreement and Consent Order \\
FIDLER & Field instrument for the detection of low-energy radiation \\
FSL & Field-screening level \\
FSR & Field-screening result \\
$\mathrm{ft}$ & Foot \\
GPS & Global Positioning System \\
GZ & Ground zero \\
HASL & Health and Safety Laboratory \\
HCA & High contamination area \\
HWAA & Hazardous waste accumulation area \\
IDW & Investigation-derived waste \\
in. & Inch \\
in./yr & Inches per year \\
K & Potassium \\
\hline $\mathrm{m}$ & Contaminant sorption coefficient \\
keV & Miloelectron volt \\
Hiliters per gram
\end{tabular}




\section{List of Acronyms and Abbreviations (Continued)}

\begin{tabular}{|c|c|}
\hline $\mathrm{mm} / \mathrm{yr}$ & Millimeters per year \\
\hline mrem/IA-yr & Millirem per Industrial Area year \\
\hline mrem/OA-yr & Millirem per Occasional Use Area year \\
\hline mrem/RW-yr & Millirem per Remote Work Area year \\
\hline $\mathrm{mrem} / \mathrm{yr}$ & Millirem per year \\
\hline NAC & Nevada Administrative Code \\
\hline NAD & North American Datum \\
\hline NAEG & Nevada Applied Ecology Group \\
\hline $\mathrm{NaI}$ & Sodium iodide \\
\hline $\mathrm{Nb}$ & Niobium \\
\hline NDEP & Nevada Division of Environmental Protection \\
\hline NEPA & National Environmental Policy Act \\
\hline NNSA/NFO & $\begin{array}{l}\text { U.S. Department of Energy, National Nuclear Security Administration } \\
\text { Nevada Field Office }\end{array}$ \\
\hline NNSS & Nevada National Security Site \\
\hline $\mathrm{Np}$ & Neptunium \\
\hline $\mathrm{Pa}$ & Protactinium \\
\hline PAL & Preliminary action level \\
\hline $\mathrm{Pb}$ & Lead \\
\hline PCB & Polychlorinated biphenyl \\
\hline $\mathrm{pCi} / \mathrm{g}$ & Picocuries per gram \\
\hline PET & Potential evapotranspiration \\
\hline PPE & Personal protective equipment \\
\hline PSM & Potential source material \\
\hline $\mathrm{Pu}$ & Plutonium \\
\hline QA & Quality assurance \\
\hline QAP & Quality Assurance Plan \\
\hline
\end{tabular}




\section{List of Acronyms and Abbreviations (Continued)}

\begin{tabular}{|c|c|}
\hline QC & Quality control \\
\hline $\mathrm{r}^{2}$ & Coefficient of determination \\
\hline RBCA & Risk-based corrective action \\
\hline RCRA & Resource Conservation and Recovery Act \\
\hline REOP & Real Estate/Operations Permit \\
\hline RIDP & Radionuclide Inventory and Distribution Program \\
\hline RMA & Radioactive material area \\
\hline RRMG & Residual radioactive material guideline \\
\hline RWMS & Radioactive waste management site \\
\hline $\mathrm{Sr}$ & Strontium \\
\hline SVOC & Semivolatile organic compound \\
\hline Tc & Technetium \\
\hline TED & Total effective dose \\
\hline Th & Thorium \\
\hline $\mathrm{Tl}$ & Thallium \\
\hline TLD & Thermoluminescent dosimeter \\
\hline ТPH & Total petroleum hydrocarbons \\
\hline TRS & Terrestrial radiation survey \\
\hline TSCA & Toxic Substances Control Act \\
\hline $\mathrm{U}$ & Uranium \\
\hline UCL & Upper confidence limit \\
\hline UR & Use restriction \\
\hline URMA & Underground radioactive material area \\
\hline USGS & U.S. Geological Survey \\
\hline UTM & Universal Transverse Mercator \\
\hline VOC & Volatile organic compound \\
\hline
\end{tabular}




\section{Executive Summary}

Corrective Action Unit (CAU) 568 is located in Area 3 of the Nevada National Security Site, which is approximately 65 miles northwest of Las Vegas, Nevada. CAU 568 is a grouping of sites where there has been a suspected release of contamination associated with nuclear testing. This document describes the planned investigation of CAU 568, which comprises the following corrective action sites (CASs):

- 03-23-17, S-3I Contamination Area

- 03-23-19, T-3U Contamination Area

- 03-23-20, Otero Contamination Area

- 03-23-22, Platypus Contamination Area

- 03-23-23, San Juan Contamination Area

- 03-23-26, Shrew/Wolverine Contamination Area

These sites are being investigated because existing information on the nature and extent of potential contamination is insufficient to evaluate and recommend corrective action alternatives (CAAs). Additional information will be obtained by conducting a corrective action investigation before evaluating CAAs and selecting the appropriate corrective action for each CAS. The results of the field investigation will support a defensible evaluation of viable CAAs that will be presented in the investigation report.

The sites will be investigated based on the data quality objectives (DQOs) developed on August 27, 2013, by representatives of the Nevada Division of Environmental Protection and the U.S. Department of Energy (DOE), National Nuclear Security Administration Nevada Field Office. The DQO process was used to identify and define the type, amount, and quality of data needed to develop and evaluate appropriate corrective actions for CAU 568. The site investigation process will also be conducted in accordance with the Soils Activity Quality Assurance Plan, which establishes requirements, technical planning, and general quality practices to be applied to this activity.

The potential contamination sources associated with CAU 568 are from nuclear testing activities conducted in Area 3. The DQO process resulted in an assumption that total effective dose (TED) within the default contamination boundaries exceeds the final action level (FAL) and requires corrective action. The presence and nature of contamination outside the default contamination boundaries at CAU 568 will be evaluated based on information collected from a field investigation. 
Radiological contamination will be evaluated based on a comparison of the TED at sample locations to the dose-based FAL. The TED will be calculated as the total of separate estimates of internal and external dose. Results from the analysis of soil samples will be used to calculate internal radiological dose. Thermoluminescent dosimeters placed at the center of each sample location will be used to measure external radiological dose.

Appendix A provides a detailed discussion of the DQO methodology and the DQOs specific to each CAS.

This Corrective Action Investigation Plan has been developed in accordance with the Federal Facility Agreement and Consent Order that was agreed to by the State of Nevada;

DOE, Environmental Management; U.S. Department of Defense; and DOE, Legacy Management. Under the Federal Facility Agreement and Consent Order, this Corrective Action Investigation Plan will be submitted to the Nevada Division of Environmental Protection for approval. Fieldwork will be conducted after the plan is approved. 


\subsection{Introduction}

This Corrective Action Investigation Plan (CAIP) contains activity-specific information, including facility descriptions, environmental sample collection objectives, and criteria for conducting site investigation activities at Corrective Action Unit (CAU) 568: Area 3 Plutonium Dispersion Sites, Nevada National Security Site (NNSS), Nevada.

This CAIP has been developed in accordance with the Federal Facility Agreement and Consent Order (FFACO) (1996, as amended) that was agreed to by the State of Nevada; U.S. Department of Energy (DOE), Environmental Management; U.S. Department of Defense; and DOE, Legacy Management.

CAU 568 is located in Area 3 of the NNSS, which is approximately 65 miles (mi) northwest of Las Vegas, Nevada. CAU 568 comprises six corrective action sites (CASs) as listed in Table 1-1 and shown on Figures 1-1 and 1-2.

The corrective action investigation (CAI) will include field inspections, radiological surveys, geophysical surveys, sampling of environmental media, analysis of samples, and assessment of investigation results. Data will be obtained to support evaluations of corrective action alternatives (CAAs) and waste management decisions.

\subsection{Purpose}

The CASs in CAU 568 are being investigated because hazardous and/or radioactive contaminants may be present in concentrations that exceed risk-based corrective action (RBCA) levels. Existing information on the nature and extent of potential contamination is insufficient to evaluate and recommend CAAs for the CASs. Additional information will be generated by conducting a CAI before evaluating and selecting CAAs.

\subsubsection{CAU 568 History and Description}

CAU 568, Area 3 Plutonium Dispersion Sites, is located in the western portion of Area 3. This CAU consists of the releases of radionuclides to the surface and subsurface soil from the conduct of two 
underground safety experiments (Otero and San Juan), three underground weapons-related tests (Platypus, Shrew, and Wolverine), and one atmospheric safety experiment (Chavez). The CAU 568 sites were used to support nuclear testing conducted in the Yucca Flat area from the 1950s through the early 1960s. Operational histories for each CAU 568 release are detailed in Section 2.2. The releases of radionuclides from these CASs are referred to as their respective test names throughout the document.

The CAI for CAU 568 will include releases of radioactivity to the soil surface from 20 nearby underground tests that are not currently CASs. The documented atmospheric releases from the following underground tests have been included in the scope of CAU 568: Solendon, Tendrac, Tuna, Cognac, Chinchilla II, Stoat, Chinchilla, Armadillo, Haymaker, Boomer, Pascal-A, Colfax, Pascal-B, Luna, Bernalillo, Pascal-C, Valencia, Mink, Chipmunk, and Funnel. The ground zeros (GZs) for these underground tests are shown on Figure 1-1, and the releases from these tests are referred to as their respective test names throughout the document.

Migration of contaminants from the test releases may have occurred at the site. During recent precipitation events, a minor drainage was identified flowing from the contamination area (CA) on the north side of 3-03 Road into a nearby crater. Additional visual surveys will be conducted during the CAI to identify any other drainages at CAU 568.

Other releases are present at CAU 568. Four soil and debris piles in the vicinity may have released contaminants to the soil. One of the soil and debris piles is located within a high contamination area (HCA).

During visual surveys, potential releases of lead to the soil from two lead-acid batteries, lead plates, a lead brick, and a lead sheet were identified. Lead plates are present on the GZ pad for San Juan, within the HCA. One additional lead plate is present within a soil and debris pile south of the CA at San Juan and Otero. A lead-acid battery and a lead brick are present within another soil and debris pile south of the CA at San Juan and Otero. A lead sheet is present on the southeasternmost soil and debris pile. The second battery and a transformer, which may have released chemical contaminants to the soil, are present within the CA at San Juan and Otero. The potential release of chemical contaminants from oil sprayed on windrows to fix contamination in place was identified south of the CA at San Juan and Otero. This former windrow area is referred to as "Windrows" in the document. 


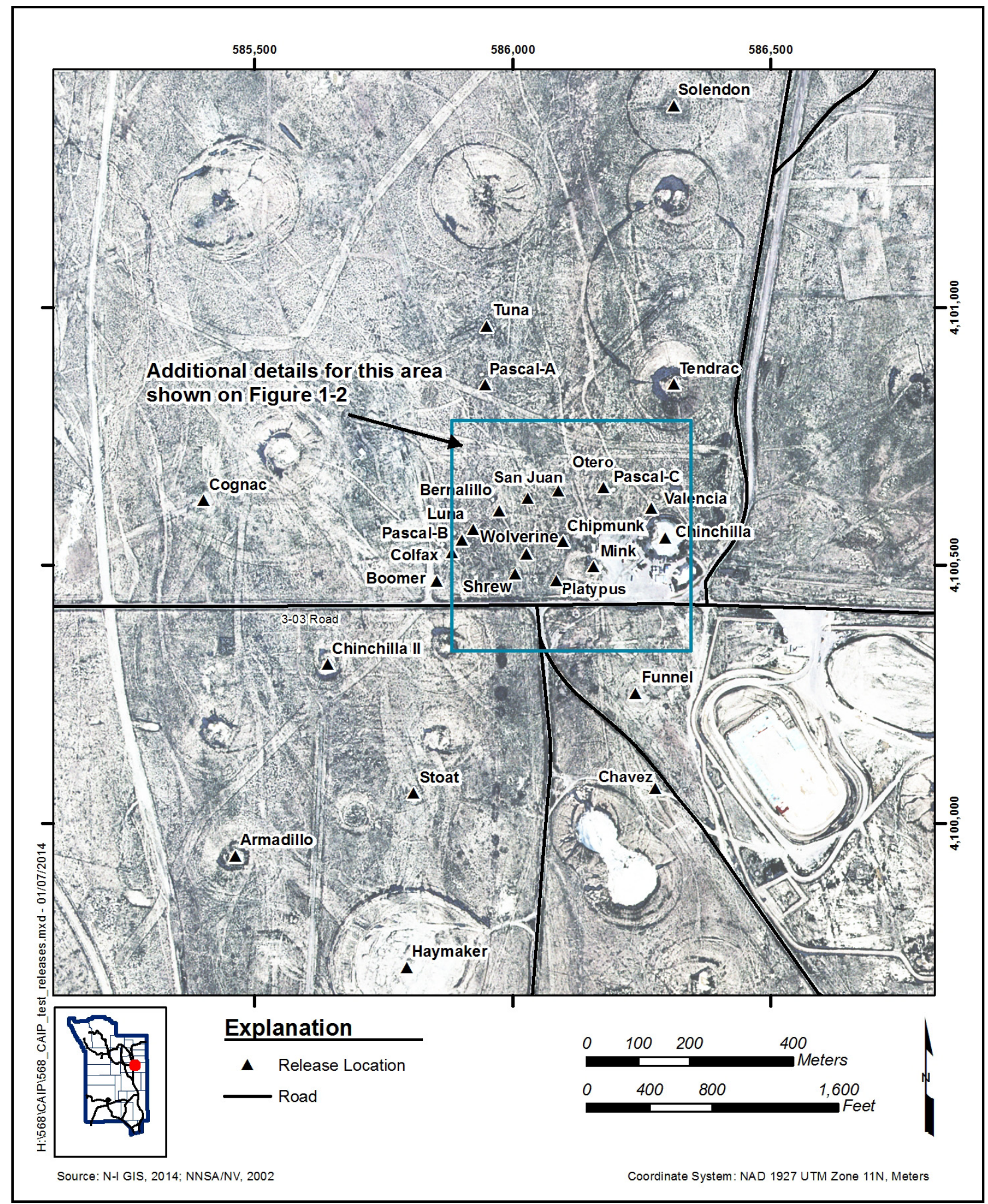

Figure 1-1

CAU 568 Release Location Map 
Table 1-1 contains a list of CASs and their associated releases. Figures 1-1 and 1-2 show the locations of these additional releases included within the scope of CAU 568.

Table 1-1

CAU 568 CASs and Associated Releases

\begin{tabular}{|c|c|c|c|}
\hline Potential Release & FFACO CASs & CAS Description & Study Group \\
\hline Chavez & 03-23-17, 03-23-19 & $\begin{array}{l}\text { S-3I Contamination Area; } \\
\text { T-3U Contamination Area }\end{array}$ & 1 \\
\hline Otero & $03-23-20$ & Otero Contamination Area & 1 \\
\hline Platypus & $03-23-22$ & Platypus Contamination Area & 1 or $3^{a}$ \\
\hline San Juan & \multirow{10}{*}{$03-23-23$} & \multirow{10}{*}{ San Juan Contamination Area } & 1 \\
\hline Windrows $^{b}$ & & & 1 \\
\hline Transformer $^{b}$ & & & \multirow{8}{*}{4} \\
\hline Lead Battery within $\mathrm{CA}^{\mathrm{b}}$ & & & \\
\hline Lead Battery in Debris Pile ${ }^{b}$ & & & \\
\hline Lead Brick in Debris Pile ${ }^{b}$ & & & \\
\hline Lead Plate in Debris Pile ${ }^{b}$ & & & \\
\hline Lead Plates in $\mathrm{HCA}^{\mathrm{b}}$ & & & \\
\hline Lead Sheet in Debris Pile ${ }^{b}$ & & & \\
\hline 4 Soil and Debris Piles ${ }^{b}$ & & & \\
\hline Shrew and Wolverine & \multirow[b]{3}{*}{$03-23-26$} & \multirow[b]{3}{*}{$\begin{array}{l}\text { Shrew/Wolverine } \\
\text { Contamination Area }\end{array}$} & 1 or $3^{a}$ \\
\hline Drainages $^{\mathrm{b}}$ & & & 5 \\
\hline $\begin{array}{l}\text { Solendon, Tendrac, Tuna, Cognac, } \\
\text { Chinchilla II, Stoat, Chinchilla, } \\
\text { Armadillo, Haymaker, Boomer, } \\
\text { Pascal-A, Colfax, Pascal-B, Luna, } \\
\text { Bernalillo, Pascal-C, Valencia, } \\
\text { Mink, Chipmunk, and Funnel }\end{array}$ & & & 2 or $3^{a}$ \\
\hline
\end{tabular}

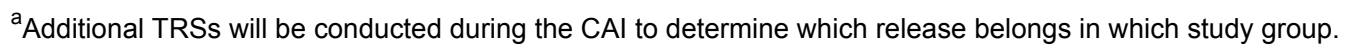

${ }^{b}$ Release not assigned a CAS number but included with this CAS for closure.

TRS $=$ Terrestrial radiation survey 


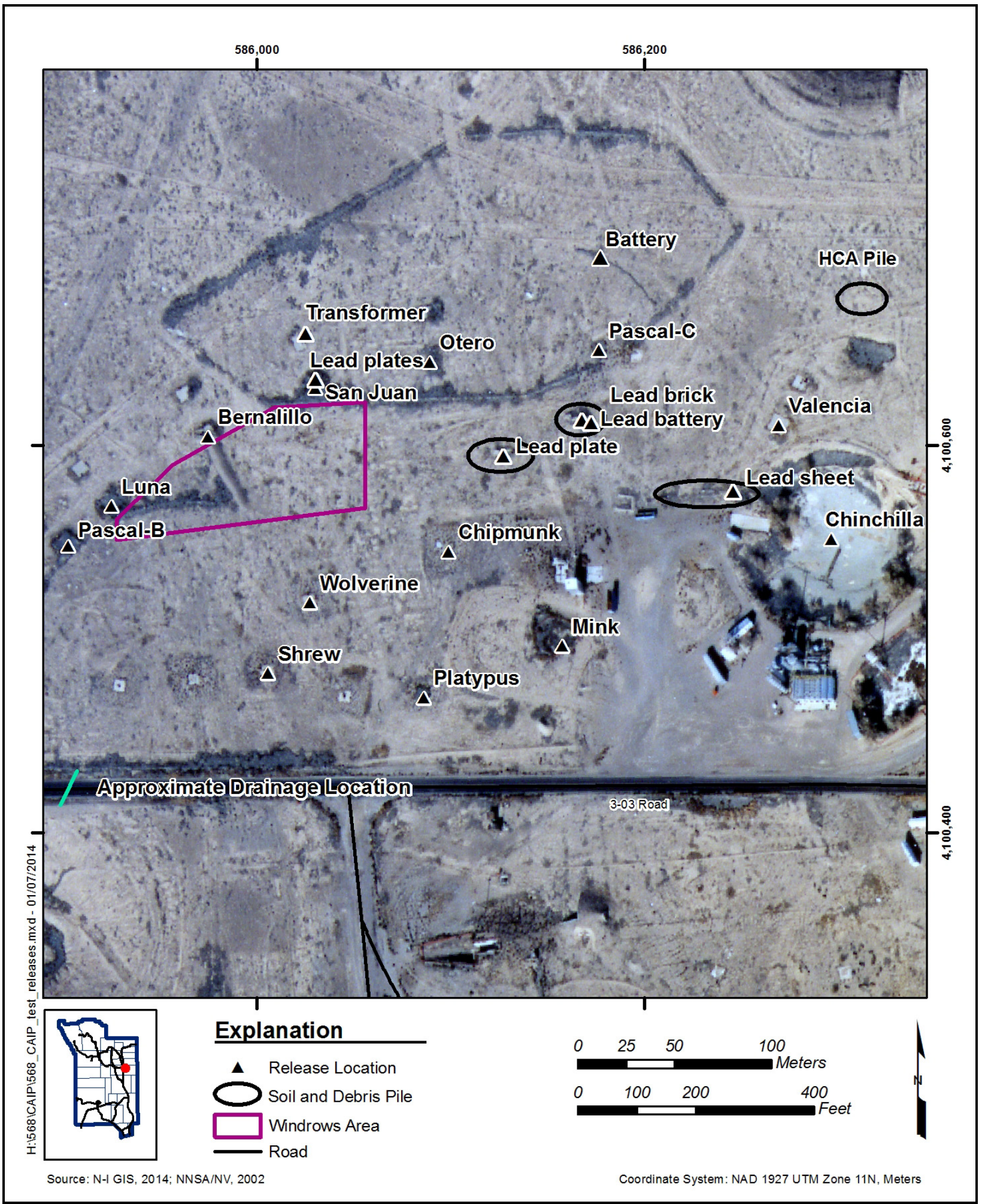

Figure 1-2

CAU 568 Release Location Map 


\subsubsection{Data Quality Objective Summary}

The sites will be investigated based on data quality objectives (DQOs) developed by representatives of the Nevada Division of Environmental Protection (NDEP) and the DOE, National Nuclear Security Administration Nevada Field Office (NNSA/NFO). DQOs are used to identify and define the type, amount, and quality of data needed to develop and evaluate appropriate corrective actions for CAU 568. This CAIP describes the investigative approach developed to collect the necessary data identified in the DQO process. Discussions of the DQO methodology and the DQOs specific to CAU 568 are presented in Appendix A. A summary of the DQO process is provided below.

The DQO problem statement for CAU 568 is as follows: "Existing information on the nature and extent of potential contamination is insufficient to evaluate and recommend CAAs for the CASs in CAU 568.” To address this problem, resolution of the decision statements presented in Section 3.4 is required. The informational inputs and data needs to resolve the problem statement and the decision statements were generated as part of the DQO process for this CAU and are documented in Appendix A.

A probabilistic sampling design will be used to collect samples from unbiased locations within an area that can be readily defined by distinct characteristics where the assumed distribution of contamination is relatively uniform. Results from these locations will be used to infer a characteristic representative of the sampled area as a whole (i.e., representing the average of the entire area, not the maximum at any one location). The characteristic normally used to define contamination within an area is the 95 percent upper confidence limit (UCL) of the mean concentration or dose.

DQOs for CAU 568 defined similarities in conceptual site model (CSM) properties of several releases that would allow a common investigative approach (e.g., surface deposition of relatively immobile contaminants, migration and mixing of contaminants in drainage channels, or similarities in release sources such as weapons tests or safety experiments). Based on these similarities, study groups were established to simplify the planning and investigation of various releases.

The potential releases to be investigated in the CAU 568 CAI will be assigned into study groups and assigned to CASs. While the need for corrective action is evaluated for each release, investigation strategies are defined at the study group level and CAAs are implemented at the FFACO CAS level. 
Additional radiological surveys and crater stability studies will be conducted, and the releases will be assigned to either Study Group 1, 2 or 3, depending on the results.

\section{Study Group 1, Releases within a Defined Radiological Survey Signature: This release category} is specific to the atmospheric deposition of radionuclide contamination from weapons-related tests and safety experiments. The release is composed mainly of fission and activated products from the weapons tests, and unfissioned nuclear material (from the scattering of nuclear material due to the detonation of chemical explosives) from safety experiments onto the soil surface that has not been displaced through excavation or migration. The contamination associated with this type of release is limited to the top 5 centimeters $(\mathrm{cm})$ of soil. Atmospheric releases of radionuclides that have been distributed at the NNSS from nuclear testing have been found to be concentrated in the upper $5 \mathrm{~cm}$ of undisturbed soil (McArthur and Kordas, 1983 and 1985; Gilbert et al., 1977; Tamura, 1977). This study group also investigates radionuclide contamination that was initially deposited on the soil surface but has been subsequently displaced or covered through mechanical means (e.g., blading, windrow formation, reworking of soil for subsequent activities in the area).

\section{Study Group 2, Releases Located within a Crater or Potential Crater Area That Cannot Be}

Entered: This group investigates subsidence craters where there has been a documented release of radioactivity to the surface from the associated underground test. Subsidence craters are considered to be the area above underground nuclear tests that have formed a surface crater or have the potential to form a surface crater. These areas have been determined to pose a significant physical safety hazard, and most are fenced and/or posted to keep workers from inadvertently being exposed to this hazard. These subsidence craters will be evaluated using the subsidence crater strategy as presented in the Soils RBCA document (NNSA/NFO, 2013). If contamination extends beyond the subsidence crater boundary, that contamination will be addressed within Study Group 1.

\section{Study Group 3, Releases with No Radiological Survey Signature: This group investigates} documented releases of radioactivity to the surface from the associated underground test; however, there is no radiological survey signature. Documented releases that were identified at the time of the test were either short-lived radionuclides or released at low concentrations such that the remaining activities are insufficient to be detected by the aerial or terrestrial radiological survey instruments. 
Study Group 4, Spills and Debris: This group investigates any chemical or radiological contamination associated with features or items such as debris, spills, contaminated areas, and piles/mounds. The debris will be evaluated for potential source material (PSM), and spills will be evaluated based on the presence of biasing factors such as discoloration or elevated instrument readings.

Study Group 5, Drainages: This group investigates radionuclide contamination that was initially deposited onto the soil surface but has subsequently been displaced through erosion.

The RBCA dose evaluation does not address the potential for removable contamination under different exposure scenarios if it were to be transported to other areas. Removable contamination is radioactive material that can be removed from surfaces by nondestructive means such as casual contact, wiping, brushing, or washing. A discussion on the risks associated with removable radioactive contamination is presented in the Soils RBCA document (NNSA/NFO, 2013). This discussion proposes a requirement for corrective action at areas that exceed HCA criteria even though the area may not present a potential radiation dose to a receptor that exceeds the final action level (FAL). It is assumed that removable contamination that exceeds HCA criteria requires corrective action. Therefore, areas that exceed HCA criteria will be defined as default contamination boundaries (DCBs), and additional information will not be collected during the CAU 568 CAI to evaluate contamination within these boundaries.

DCBs will also be established for subsurface contamination associated with underground safety experiments that vented radioactivity to the soil surface. Although it can be verified whether contamination on the surface poses a risk to site workers, it is not feasible to verify whether subsurface contamination along the venting flow path is present and poses a risk to site workers. Therefore, by establishing a DCB at these sites, workers will be protected from inadvertent exposure to contaminants if the subsurface soil contamination were exposed. See Section 4.1 for details regarding the DCBs.

Subsidence craters affect the closure of Soils Activity sites when there has been a release of radioactivity to the surface from the associated underground test. Subsidence craters are considered to be the area above underground nuclear tests that have formed a surface crater or have the potential to form a surface crater. These areas have been determined to pose a significant physical safety hazard, 
and most are fenced and/or posted to keep workers from inadvertently being exposed to this hazard. It will be determined during the CAI which subsidence craters can be entered and which cannot. For the subsidence craters that cannot be entered, these releases will be evaluated using the subsidence crater strategy as presented in the Soils RBCA document (NNSA/NFO, 2013). Subsidence craters or potential crater areas that have been determined to have a sufficiently low potential for subsidence or additional subsidence will be investigated without regard to the crater or potential crater area.

\subsection{Scope}

To generate information needed to resolve the decision statements identified in the DQO process, the scope of the CAI for CAU 568 includes the following activities:

- Move surface debris and/or materials, as needed, to facilitate sampling.

- Conduct radiological and geophysical surveys.

- $\quad$ Perform field screening.

- Measure in situ external dose rates using thermoluminescent dosimeters (TLDs) or other dose-measurement devices.

- Collect and submit environmental samples for laboratory analysis to determine whether any contaminant of concern (COC) is present.

- Collect and submit environmental samples for laboratory analysis to determine the nature and extent of any COCs that are present.

- Collect samples of waste material, if present, to determine the potential for a release to result in contamination exceeding FALs.

- $\quad$ Collect quality control (QC) samples.

Contamination of environmental media originating from activities not identified in the CSM will not be considered as part of this CAU unless the CSM and the DQOs are modified to include the release. If not included in the CSM, contamination originating from these sources will not be considered for sample location selection and/or will not be considered COCs. If such contamination is present, the contamination will be identified as part of another CAS (either new or existing). 


\subsection{CAIP Contents}

Section 1.0 presents the purpose and scope of this CAIP, while Section 2.0 provides background information about CAU 568. Objectives of the investigation, including the CSM, are presented in Section 3.0. Field investigation and sampling activities are discussed in Section 4.0, and waste management issues are discussed in Section 5.0. General field and laboratory quality assurance (QA) (including collection of QA samples) is presented in Section 6.0 and in the Soils Activity Quality Assurance Plan (QAP) (NNSA/NSO, 2012). The activity schedule and records availability are discussed in Section 7.0. Section 8.0 provides a list of references.

Appendix A provides a detailed discussion of the DQO methodology and the DQOs specific to each CAS, while Appendix B contains information on the activity organization. Appendix C contains NDEP comments on the draft version of this document. 


\subsection{Facility Description}

CAU 568 comprises 6 CASs located within Area 3 of the NNSS. The investigation will also address potential contamination associated with 20 documented releases (venting) from underground testing in the vicinity of the CAU 568 CASs. These releases were organized into study groups based on their type of release and investigative approach.

\subsection{Physical Setting}

The following subsections describe the general physical settings of Area 3 of the NNSS. General background information pertaining to topography, geology, hydrogeology, and climatology is provided for these specific areas of the NNSS region in the Geologic Map of the Nevada Test Site, Southern Nevada (Frizzell and Shulters, 1990); CERCLA Preliminary Assessment of DOE's Nevada Operations Office Nuclear Weapons Testing Areas (DRI, 1988); Final Environmental Impact Statement, Nevada Test Site, Nye County, Nevada (ERDA, 1977); and the Final Environmental Impact Statement for the Nevada Test Site and Off-Site Locations in the State of Nevada (DOE/NV, 1996).

CAU 568 is located within the Yucca Flat Hydrographic Area of the NNSS. Yucca Flat is a closed basin, which is slowly being filled with alluvial deposits eroding from the surrounding mountains (Laczniak et al., 1996).

Local topography around the CAU is relatively flat and slopes gently to the south. Precipitation runoff flow from CAU 568 is generally to the south, into the Yucca Flat dry lake. Several craters present within the area have disturbed the ground surface and may affect drainage.

CAU 568 is located within the Yucca Flat Tributary Flow System, a part of regional carbonate aquifer flow system, and moves generally from northeast to southwest (Fenelon et al., 2010). Within the overlying alluvial and volcanic aquifers, lateral groundwater flow occurs from the margins to the center of the basin and downward into the carbonate aquifer (Laczniak et al., 1996). The nearest rain gauge to the site is Buster Jangle Y (BJY), located in Area 1. Average annual precipitation at this rain gauge is $16.1 \mathrm{~cm}$ (6.3 inches [in.]) (Soule, 2006). Average annual potential evapotranspiration (PET) 
has been estimated for the Area 3 Radioactive Waste Management Site (RWMS) as $156.7 \mathrm{~cm}$ (61.7 in.) (Yucel, 2009). Rainfall and PET data are presented in Table 2-1.

Table 2-1

Rainfall and PET Information for Yucca Flat

\begin{tabular}{|c|c|c|}
\hline & $\begin{array}{c}\text { Area 3 PET } \\
\text { (cm) }\end{array}$ & $\begin{array}{c}\text { BJY } \\
\text { Precipitation } \\
\text { (cm) }\end{array}$ \\
\hline \hline Minimum & 150.2 & 3.8 \\
\hline Maximum & 160.8 & 37.4 \\
\hline Mean & 156.7 & 16.1 \\
\hline $95 \%$ UCL & 159.6 & 18.2 \\
\hline
\end{tabular}

Source: Soule, 2006; Yucel, 2009

The nearest groundwater well to CAU 568 is U.S. Geological Survey (USGS) Water Well WW-A, an active well located approximately $0.6 \mathrm{mi}$ southwest of the site (USGS, 2013). The most recent recorded depth to the water table is approximately 1,600 feet (ft) below ground surface (bgs). The thickness of the unsaturated zone extends to more than $600 \mathrm{ft}$ bgs (Hevesi et al., 2003).

\subsection{Operational History}

The following subsections provide a description of the use and history of each potential release site in CAU 568. The site-specific summaries are designed to describe the current definition of each site and document all significant, known activities.

\subsubsection{Chavez}

Chavez consists of the release of radiological contaminants to the atmosphere from the tower detonation of the Chavez safety experiment. These contaminants were distributed in a roughly concentric pattern on the soil surface, generally decreasing in concentration with increasing distance from the release location. The Chavez (T-3U) safety experiment was conducted as part of Operation Hardtack II on October 27, 1958. The test had a 0.6-ton yield and was detonated at a height of $52.5 \mathrm{ft}$ atop a wooden tower (DOE/NV, 2000b; Holmes \& Narver, 1958). The GZ area is within a CA, and an HCA is located just south of GZ. Old berms appear within the HCA where the original surface 
contamination may have been covered over (DOE/NV, 2000a). An additional CA is located across Angle Road from the GZ for Chavez and contains alpha-contaminated soil and debris. Figure 2-1 shows the site layout for Chavez.

\subsubsection{Otero}

Otero consists of the release of radiological contaminants to the atmosphere from the venting of the Otero safety experiment. These contaminants were distributed in a roughly concentric pattern on the soil surface, generally decreasing in concentration with increasing distance from the release location. The Otero (U-3q) shaft safety experiment was conducted as part of Operation Hardtack II on September 12, 1958 (DOE/NV, 2000b). The test had a 38-ton yield and was detonated at a depth of $480 \mathrm{ft}$ bgs in a 500-ft-deep cased hole that was capped with a steel cover plate. A 30-ft-square concrete slab at the surface supported a 20-by-20-by-60-ft high head tower (Holmes \& Narver, 1958). A CA fence currently surrounds the GZ area for this test. Figure 2-2 shows the site layout for Otero.

\subsubsection{Platypus}

Platypus consists of the release of radiological contaminants to the atmosphere from the venting of the Platypus weapons-related test. These contaminants were distributed in a roughly concentric pattern on the soil surface, generally decreasing in concentration with increasing distance from the release location. The Platypus (U-3ad) weapons-related shaft test was conducted as part of Operation Nougat on February 24, 1962 (DOE/NV, 2000b). The test had a low yield and was detonated at a depth of $190 \mathrm{ft}$ bgs in alluvium (GE, 1979). Two CA fence lines surround components from this test. Figure 2-2 shows the site layout for Platypus.

\subsubsection{San Juan}

San Juan consists of the release of radiological contaminants to the atmosphere from the venting of the San Juan safety experiment. These contaminants were distributed in a roughly concentric pattern on the soil surface, generally decreasing in concentration with increasing distance from the release location. The San Juan (U-3p) shaft safety experiment was conducted as part of Operation Hardtack II on October 20, 1958 (DOE/NV, 2000b). The test had a zero yield and was detonated at a depth of $234 \mathrm{ft}$ bgs in a 250-ft-deep cased hole that was capped with a steel cover plate. A 30-ft-square concrete slab at the surface supported a 20-by-20-by-60-ft high head tower (Holmes \& Narver, 1958). 


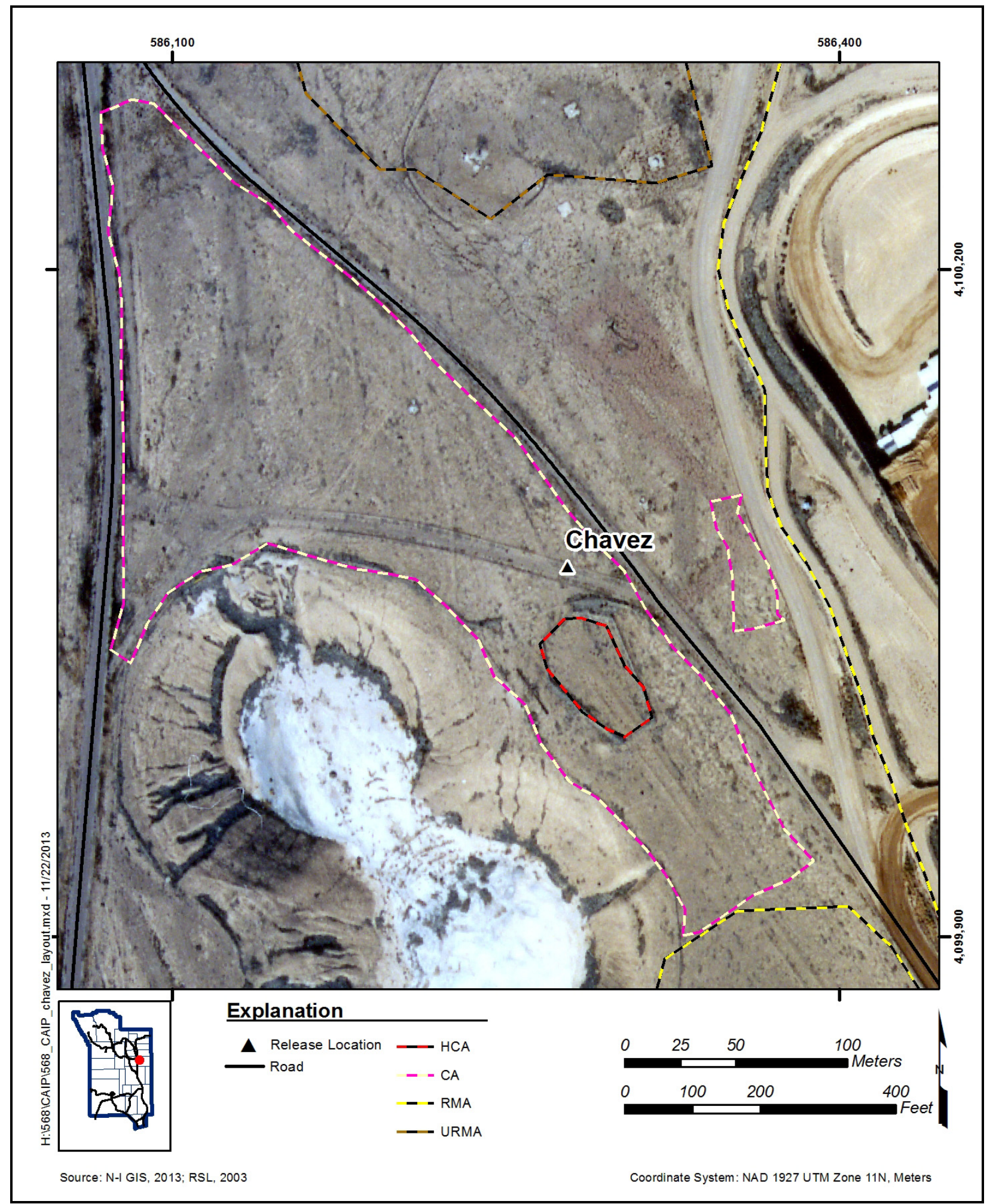

Figure 2-1 Chavez Site Layout 


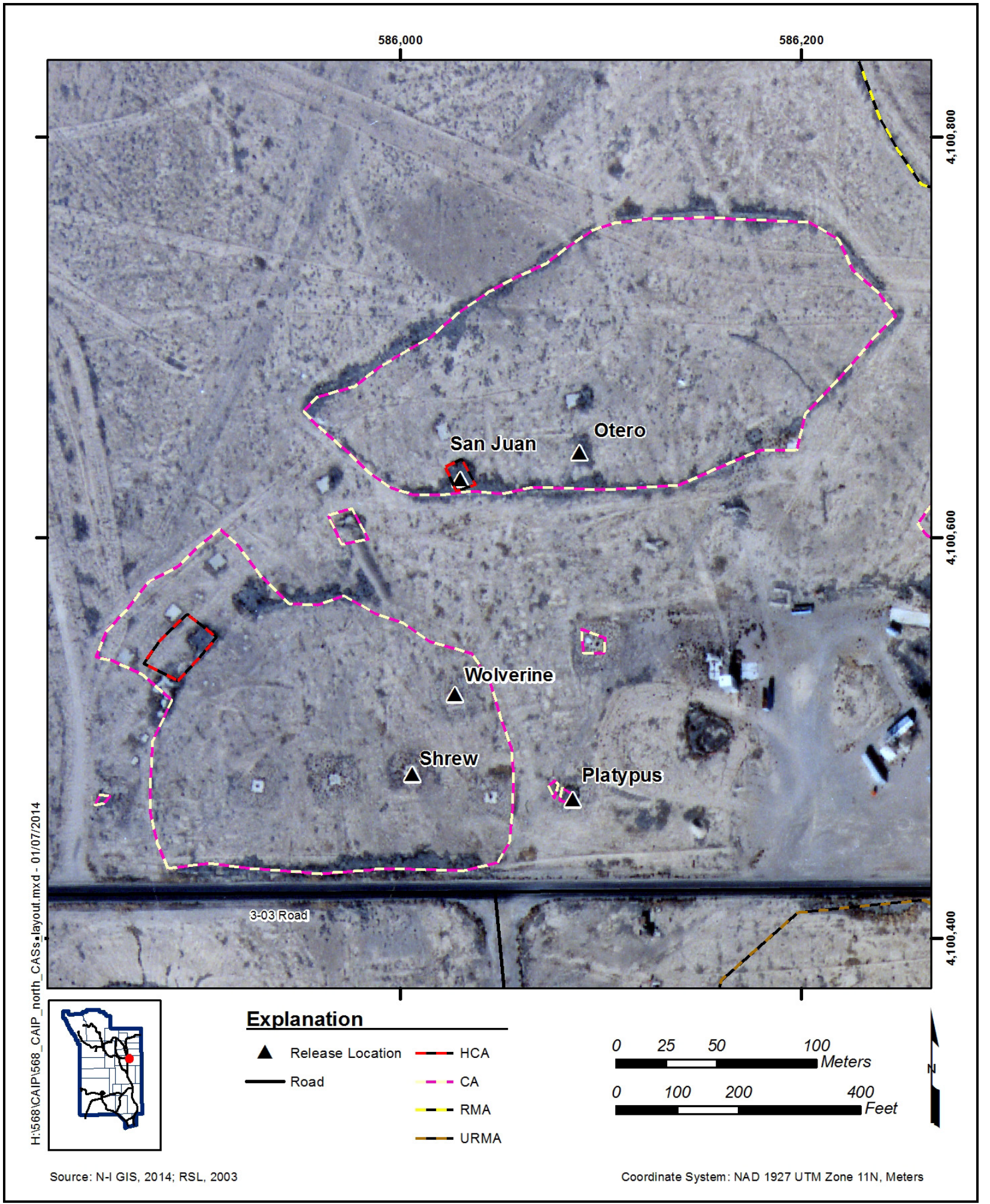

Figure 2-2

Otero, San Juan, Platypus, Shrew, and Wolverine Site Layout 
According to historical documentation, "there was essentially no nuclear yield from the San Juan explosion, and no visible venting occurred. There was, however, some alpha contamination detected in the immediate vicinity of the well in which this device was detonated” (GE, 1979). The GZ pad is currently located within an HCA, while the surrounding area is posted as a CA. Figure 2-2 shows the site layout for San Juan.

\subsubsection{Shrew and Wolverine}

Shrew and Wolverine consist of the release of radiological contaminants to the atmosphere from the venting of the Shrew and Wolverine weapons-related tests. These contaminants were distributed in a roughly concentric pattern on the soil surface, generally decreasing in concentration with increasing distance from the release location. Shrew (U-3ac) was conducted as part of Operation Nougat on September 16, 1961 (DOE/NV, 2000b). Shrew had a low yield and was detonated at a depth of 325 ft bgs in slightly consolidated alluvium (Holmes \& Narver, 1958; GE, 1979; Schoengold et al., 1996). Wolverine (U-3av) was conducted as part of Operation Storax on October 12, 1962 (DOE/NV, 2000b). Wolverine had a low yield and was detonated at a depth of $240 \mathrm{ft}$ bgs (Holmes \& Narver, 1958; Schoengold et al., 1996). A CA fence surrounds the GZ area for these and other tests in the area. An HCA is present within the northwest portion of the CA. Figure 2-2 shows the site layout for Shrew and Wolverine.

\subsubsection{Additional Surface Releases from Underground Tests}

Additional test releases were identified within the scope of CAU 568. These releases consist of the release of radiological contaminants to the atmosphere from the venting of 20 nearby underground tests that are not currently CASs. The releases were distributed in roughly concentric patterns on the soil surface, generally decreasing in concentration with increasing distance from the release location. These 20 releases will be included within the scope of CAS 03-23-26 (Shrew and Wolverine) and include the release of contaminants to the soil surface from the Cognac, Chinchilla II, Stoat, Chinchilla, Armadillo, Haymaker, Solendon, Mink, Boomer, Funnel, and Tuna weapons-related shaft tests; the Pascal-A, Colfax, Pascal-B, Luna, Bernalillo, Pascal-C, Valencia, and Chipmunk shaft safety experiments; and the Tendrac joint U.S./U.K. shaft test. These tests were conducted between 1957 and 1968 with yields ranging from slight to 67 kilotons (kt) (DOE/NV, 2000b). The locations of these test GZs are shown on Figure 1-1. 


\subsubsection{Windrows}

The release within the windrows area consists of the blading of the contaminated soil surface into windrows and the application of oils onto the surface of the windrows. There is the potential for chemical contaminants to have been released to the soil in the vicinity of the windrows due to the application of oils. This release is included within the scope of CAS 03-23-23. Historical information shows that decontamination activities were conducted in 1959 to remove debris from the area south of San Juan and Otero, and contaminated soil within the area was placed in windrows and covered with oil to fix the contamination (REECo, 1959). According to historical photographs of the area, the windrows were no longer present by the 1960s (AAS, 1964). Because the area was disturbed from the formation of the windrows and their subsequent removal, there is the potential for chemical contaminants to be present anywhere within the windrow area. The extent of the windrow area is shown on Figure 1-2.

\subsubsection{Drainages}

The release associated with drainages consists of the potential translocation of radionuclides originally distributed on the soil surface into the stormwater collection system. A minor drainage was identified flowing from the CA on the north side of 3-03 Road into a nearby crater. This drainage will be included within the scope of CAS 03-23-26. Additional visual surveys will be conducted during the CAI to identify any other drainages at CAU 568. The location of the identified drainage is shown on Figure 1-2.

\subsubsection{Transformer}

There is the potential for a release of chemical contaminants to occur or to have occurred from the transformer identified at the site to the soil underneath and surrounding the transformer. The transformer was identified on the soil surface within the CA at San Juan and Otero. The location of the transformer is shown on Figure 1-2. 


\subsubsection{Lead Items}

Page 18 of 63

There is the potential for lead to have been released from the lead items to the soil underneath and surrounding the items. The lead items that have been identified at the site will be included within the scope of CAS 03-23-23. One broken lead-acid battery was identified on the soil surface within the CA at San Juan and Otero. Lead plates were identified on the surface of the GZ pad for San Juan, within the HCA. One lead plate was identified within a soil and debris pile south of the CA at San Juan and Otero. Within another soil and debris pile south of the CA at San Juan and Otero, a lead brick and lead-acid battery were identified. One lead sheet was identified on the soil surface within the southeasternmost soil and debris pile. It is assumed that additional lead items may be present within any of the soil and debris piles. The locations of the lead items are shown on Figure 1-2.

\subsubsection{Soil and Debris Piles}

The release consists of the four soil and debris piles that were deposited onto the soil surface. There is the potential for the soil and debris piles to contain chemical or radiological contaminants or PSM. The four soil and debris piles identified at the site will be included within the scope of CAS 03-23-23. One soil and debris pile was recently posted as an HCA, while the other three retain no radiological postings. The HCA pile is located north of Valencia and east of the San Juan and Otero CA. It contains soil and small fragments of metallic debris. The other three soil and debris piles are located generally south of the San Juan and Otero CA. They contain construction-related debris (e.g., concrete, wood, metal, empty drums and buckets), lead items, and soil. The locations of the soil and debris piles are shown on Figure 1-2.

\subsection{Waste Inventory}

Available documentation, interviews with former site employees, process knowledge, and general historical NNSS practices were used to identify waste types that may be present. The potential waste types that were identified at CAU 568 include low-level radioactive waste from the test releases and drainage; hazardous, hydrocarbon, low-level radioactive, or mixed wastes from the soil and debris piles; Resource Conservation and Recovery Act (RCRA) hazardous waste from the lead items; Toxic Substances Control Act (TSCA) regulated wastes (polychlorinated biphenyls [PCBs]), hazardous, or mixed wastes from the transformer; and hydrocarbon wastes from the windrows. 
Additional wastes generated during the investigation may include sanitary waste, investigation-derived waste (IDW), decontamination liquids, and soils.

\subsection{Release Information}

All releases of contamination associated with CAU 568 are identified in Table 1-1. They are directly or indirectly associated with several nuclear tests conducted in the area. These nuclear tests released contamination to the surrounding surface soil. Exposure routes to receptors include ingestion and inhalation of radionuclides in surface soil (internal exposure). Site workers may also be exposed to direct radiation by performing activities in proximity to radiologically contaminated materials (i.e., external dose). Therefore, the CSM will include the potential for receptors to receive an internal dose from contaminated soil and an external dose from contaminated soil and debris.

Exposure routes to receptors also include exposure to hazardous or chemical releases due to PSM or other releases at CAU 568.

Migration pathways for contamination from the site include surface migration during stormwater events, wind-borne material, and material displaced from roads in the vicinity (e.g., moved during road maintenance). Contaminants also may have been disturbed through mechanical means due to windrow formation, subsequent underground testing activities, operations at the adjacent Area 3 mud plant, or construction and maintenance activities of nearby roads.

The investigation of specific releases at CAU 568 will depend upon the nature of these releases. Therefore, the releases at CAU 568 have been categorized into five Study Groups, as defined in Section 1.1.2. The following subsections contain study group-specific descriptions of known or suspected releases associated with CAU 568.

\subsubsection{Study Groups 1, 2, and 3}

The primary release at Study Groups 1, 2, and 3 will address contamination deposited onto surface soils, activated soil, and contamination deposited onto soils from underground nuclear testing. The initial release of radionuclides from the tests investigated with in CAU 568 was distributed in roughly concentric patterns on the ground surface, exhibiting a pattern of surface contamination that is generally decreasing in concentration with increasing distance from the release locations, as 
illustrated in the 2012 aerial radiological survey showing the gross count and americium signatures of the CAU 568 releases (Figures 2-3 and 2-4) (Stampahar, 2012).

Windrows were created in 1959 within the area of Study Group 1 to consolidate radiological surface soil contamination. As discussed in Section 2.2.7, these windrows may have been removed, but there is a potential that the contamination may have been mixed in the shallow subsurface due to subsequent nuclear testing activities in the area.

\subsubsection{Study Group 4}

Study Group 4 addresses releases associated with PSM present at CAU 568. There may be a release of chemical COCs to the surface and shallow subsurface soil from lead-acid batteries, lead plates, a lead brick, a lead sheet, a transformer, spills, wastes, or any additional debris from activities conducted at the site. The lead items contain exposed lead that is assumed to have the potential to release contamination to the surrounding surface and subsurface soil. An identified transformer may contain PCBs that could be released to the surrounding surface and subsurface soil. Soil and debris piles were identified at the site. These may contain items that have the potential to release contamination to the soil.

\subsubsection{Study Group 5}

The Study Group 5 release consists of contamination migration, which includes the relocation of soil contamination from atmospheric releases downgradient and into nearby craters due to stormwater runoff. Visual surveys conducted following recent rain events were used to identify the locations of drainages exiting the CAU 568 area. Additional visual surveys will be conducted during the CAI.

\subsection{Investigative Background}

All previous investigation data are assessed in the planning phase to identify bias used in the selection of appropriate sampling locations. A variety of radiation surveys were conducted in the CAU 568 area. These include aerial and terrestrial radiation surveys. Table 2-2 lists the method descriptions, advantages, limitations, spatial and spectral resolutions, measurement dates, and applied use for the different radiation surveys. Details of the surveys are also discussed in Sections 2.5.1 and 2.5.3. 


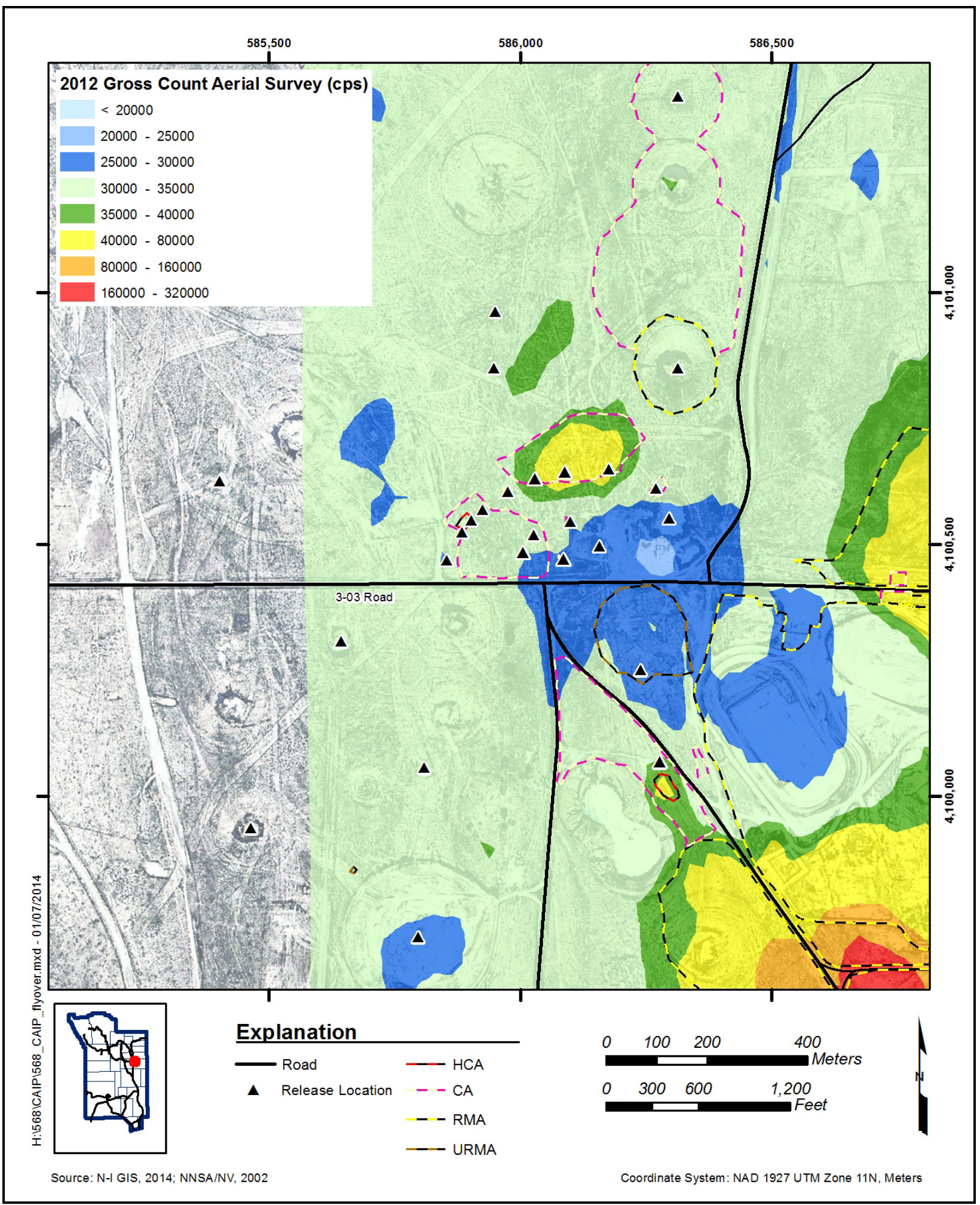

Figure 2-3

CAU 568 Gross Count Aerial Data 


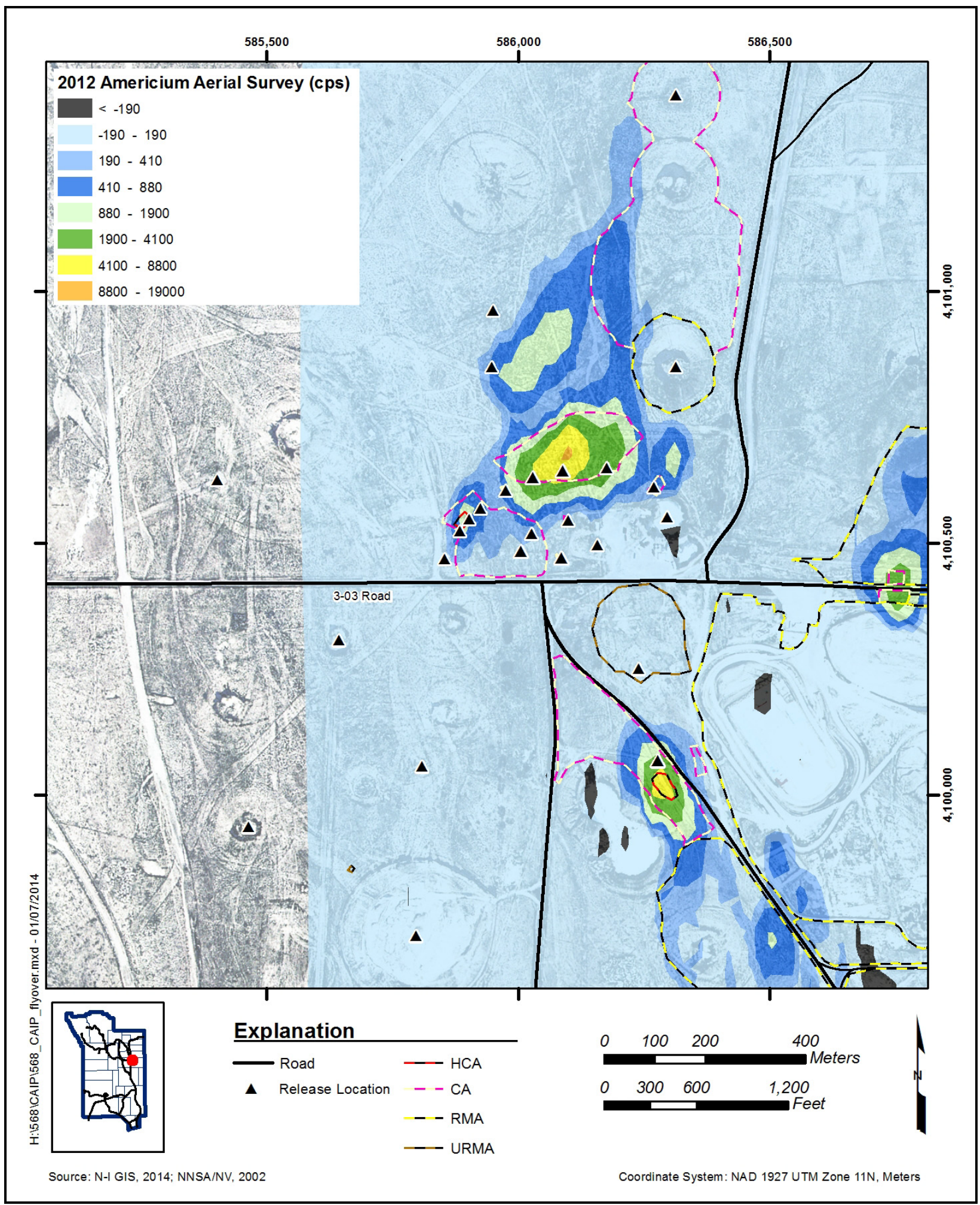

Figure 2-4

CAU 568 Americium Aerial Data 
Table 2-2

\section{Comparison of Radiation Survey Methods}

\begin{tabular}{|c|c|c|c|}
\hline & FIDLER & PRM-470 & Aerial Radiological Survey \\
\hline $\begin{array}{l}\text { Method } \\
\text { Description } \\
\text { Summary }\end{array}$ & $\begin{array}{l}\text { Ground-based instrument that } \\
\text { detects low-energy } \\
\text { gamma emissions. }\end{array}$ & $\begin{array}{l}\text { Ground-based organic plastic } \\
\text { scintillator instrument that } \\
\text { detects gamma emissions. }\end{array}$ & $\begin{array}{l}\text { Helicopter-mounted RSI System } \\
\text { with Nal detectors. }\end{array}$ \\
\hline $\begin{array}{l}\text { Advantages } \\
\text { and } \\
\text { Limitations }\end{array}$ & $\begin{array}{l}\text { Advantages: Lightweight } \\
\text { hand-held instrument designed } \\
\text { to see low-energy } \\
\text { gamma emissions. } \\
\text { Limitations: Does not } \\
\text { discriminate between low-energy } \\
\text { gamma emissions from } \\
\text { different isotopes. }\end{array}$ & $\begin{array}{l}\text { Advantages: Lightweight } \\
\text { hand-held instrument that } \\
\text { detects gamma emissions. } \\
\text { Limitations: Does not distinguish } \\
\text { between the radionuclides } \\
\text { emitting the gamma emissions. }\end{array}$ & $\begin{array}{l}\text { Advantages: Gives a wide area } \\
\text { of view (as opposed to TRSs); } \\
\text { can survey large areas quickly. } \\
\text { Limitations: Because it is } \\
\text { elevated and moving at a fast } \\
\text { rate, does not distinguish } \\
\text { small localized areas of } \\
\text { contamination or materials that } \\
\text { are contaminated. }\end{array}$ \\
\hline $\begin{array}{c}\text { Spatial } \\
\text { Resolution }\end{array}$ & $\begin{array}{l}\text { Held at } \sim 6 \text { in. above ground } \\
\text { surface, has a small field of view. }\end{array}$ & $\begin{array}{l}\text { Held at } \sim 1 \mathrm{~m} \text { above ground } \\
\text { surface, has a small field of view. }\end{array}$ & $\begin{array}{l}\text { Altitude: } 15 \mathrm{~m} \\
\text { Line Spacing: } 23 \mathrm{~m} \\
\text { 30-m diameter window }\end{array}$ \\
\hline $\begin{array}{l}\text { Spectral } \\
\text { Resolution }\end{array}$ & 10 to $100 \mathrm{keV}$ & All gamma emitters & 38 to $3,026 \mathrm{keV}$ \\
\hline $\begin{array}{l}\text { Measurement } \\
\text { Date }\end{array}$ & 05/2012 and 09/2013 & $05 / 2012$ & $03 / 2012$ \\
\hline $\begin{array}{l}\text { Applied } \\
\text { Use }\end{array}$ & $\begin{array}{l}\text { Energies in the } 59-\mathrm{keV} \text { range, } \\
\text { which are indicative of Am- } 241 \\
\text { or other higher-energy emitters; } \\
\text { used to identify Am- } 241 \\
\text { contamination as an indicator of } \\
\text { plutonium contamination. }\end{array}$ & $\begin{array}{l}\text { Nondiscriminatory gamma count } \\
\text { used to identify contamination } \\
\text { from nuclear testing. }\end{array}$ & $\begin{array}{l}\text { For Am-241: Processed for } \\
\text { energies in the } 57-\text { to } 70-k e V \\
\text { range }(\mathrm{Am}-241) \text { relative to the } \\
38-\text { to } 50-\mathrm{keV} \text { and } 70-\text { to } 82-\mathrm{keV} \\
\text { background windows. Used } \\
\text { to identify } \mathrm{Am}-241 \\
\text { contamination as an indicator } \\
\text { of plutonium contamination. } \\
\text { For man-made: Processed for } \\
\text { energies in the } 38-\text { to } 1,294-\mathrm{keV} \\
\text { window relative to the } 1,394-\text { to } \\
3,026-\mathrm{keV} \text { background window. } \\
\text { Used to identify contamination } \\
\text { from nuclear testing. }\end{array}$ \\
\hline
\end{tabular}

Source: N-I GIS, 2013; Riedhauser, 1999; Buchheit and Marianno, 2005; Stampahar, 2012; TSA Systems, 2005

In accordance with the graded approach described in the Soils QAP (NNSA/NSO, 2012), the quality required of a dataset will be determined by its intended use in decision making. TRS and aerial radiological survey data are classified as decision supporting and are not used, by themselves, to make corrective action decisions. However, the radiation surveys are used to identify bias used in the selection of sample locations and will be evaluated for use in defining corrective action boundaries in the investigation report. For defining corrective action boundaries, the radiation surveys will be used only in terms of defining a relative spatial distribution of contamination. 
The aerial radiation surveys provide spectral information that was used to differentiate specific isotopic signatures. This allows the separate mapping of Am-241 contamination, man-made gamma activity, and gross gamma activity within the surveyed areas. The presence of Am-241 is used as an indicator of the potential presence of plutonium contamination.

The radionuclide activity in this area is due to a combination of fission products (primarily high-energy gamma radiation) and unfissioned nuclear material (primarily low-energy gamma, beta, and alpha radiation). The sources of these radiation types are not necessarily co-located (see Section A.2.2.3).

The Radionuclide Inventory and Distribution Program (RIDP) conducted an investigation from 1981 through 1986 that estimated the inventory of man-made radionuclides at the NNSS through in situ gamma spectroscopy (McArthur and Mead, 1987). At some of these in situ locations, soil samples were collected and analyzed for plutonium isotopes. Based on these soil sample and gamma spectroscopy results, ratios of plutonium $(\mathrm{Pu})-239 / 240$ to Am-241 were used to infer plutonium inventories from the Am-241 inventories. These plutonium values within the scope of CAU 568 are shown on Figure 2-5 and discussed in Section 2.5.2. More detailed discussions of these investigations are found in Appendix A.

\subsubsection{Aerial Radiological Surveys}

Aerial radiological surveys were conducted within Area 3 of the NNSS in 1978, 1992, 1994, 1996, and 2012 to characterize the radiation exposure (Fritzche, 1981; BN, 1997; BN, 1999a and b; Stampahar, 2012). The overall pattern of the radiological distribution has not changed significantly from the initial 1978 survey to the 2012 survey. However, the 1996 and 2012 aerial surveys were conducted at a lower altitude $(15 \mathrm{~m})$ above ground surface with tighter line spacings (23 $\mathrm{m})$ than the previous surveys (which were predominantly conducted at an altitude of $150 \mathrm{~m}$ ). Thus, the more recent surveys provide a more precise representation of site contamination. As a result, the data from the 2012 aerial survey are referenced throughout the document and the aerial radiological signatures may be used in the biasing of sample locations or for defining the releases for Study Groups 1, 2, or 3. This survey shows that the highest levels of americium (8,800 to 19,000 counts per second [cps]) are located centered over the Otero (CAS 03-23-20) and San Juan (CAS 03-23-23) test locations. Lower levels of americium were detected over the Chavez (CAS 03-23-19) test location. The highest levels 
of gamma radiation (40,000 to 80,000 cps) are also located at these test locations. Results for the gamma and Am-241 aerial surveys covering CAU 568 are shown in Figures 2-3 and 2-4.

Note that the data reported in Figure 2-4 for americium are the values provided by the Remote Sensing Laboratory. The algorithm used by the Remote Sensing Laboratory in the calculation of americium response from the gamma flyover radiation survey data involves calculating base values that are partially dependent upon the statistical uncertainty. When the base values are subtracted from the survey data, this method sometimes results in negative values for the americium response. Common convention in reporting radiation survey results dictates that the negative numbers be reported because information is lost when the numbers are truncated to zero.

\subsubsection{RIDP and NAEG Data}

As part of an effort to assess the implications of contamination on future uses of the NNSS, the RIDP was established in 1981 to make a comprehensive survey of the important man-made radionuclides of NNSS origin in the surface soil at the site (McArthur and Mead, 1987). Data collected for the RIDP and by the Nevada Applied Ecology Group (NAEG) in the 1980s allowed for estimates of surface soil inventories throughout the NNSS. The RIDP estimated the inventory through in situ soil measurements by gamma spectroscopy and limited confirmatory soil sampling (McArthur and Mead, 1987; Gray et al., 2007). Desert Research Institute reported in situ gamma spectroscopy measurements for Area 3, which included the CAU 568 area (McArthur and Mead, 1987). Although the RIDP data present a general distribution of contamination, there is not sufficient resolution for biasing sample locations with CAU 568 because RIDP data points are typically 400 to 3,000 ft apart, and no data are available for locations between the measured points. In accordance with the graded approach described in the Soils QAP (NNSA/NSO, 2012), RIDP data are classified as informational and do not directly affect DQOs, but provide information to support conceptual models. These data support the CSM assumptions that contamination levels are greatest at release locations and generally decrease with distance from the release locations. The RIDP in situ measurements for Pu-239 within the study boundaries of CAU 568 are shown in Figure 2-5. 


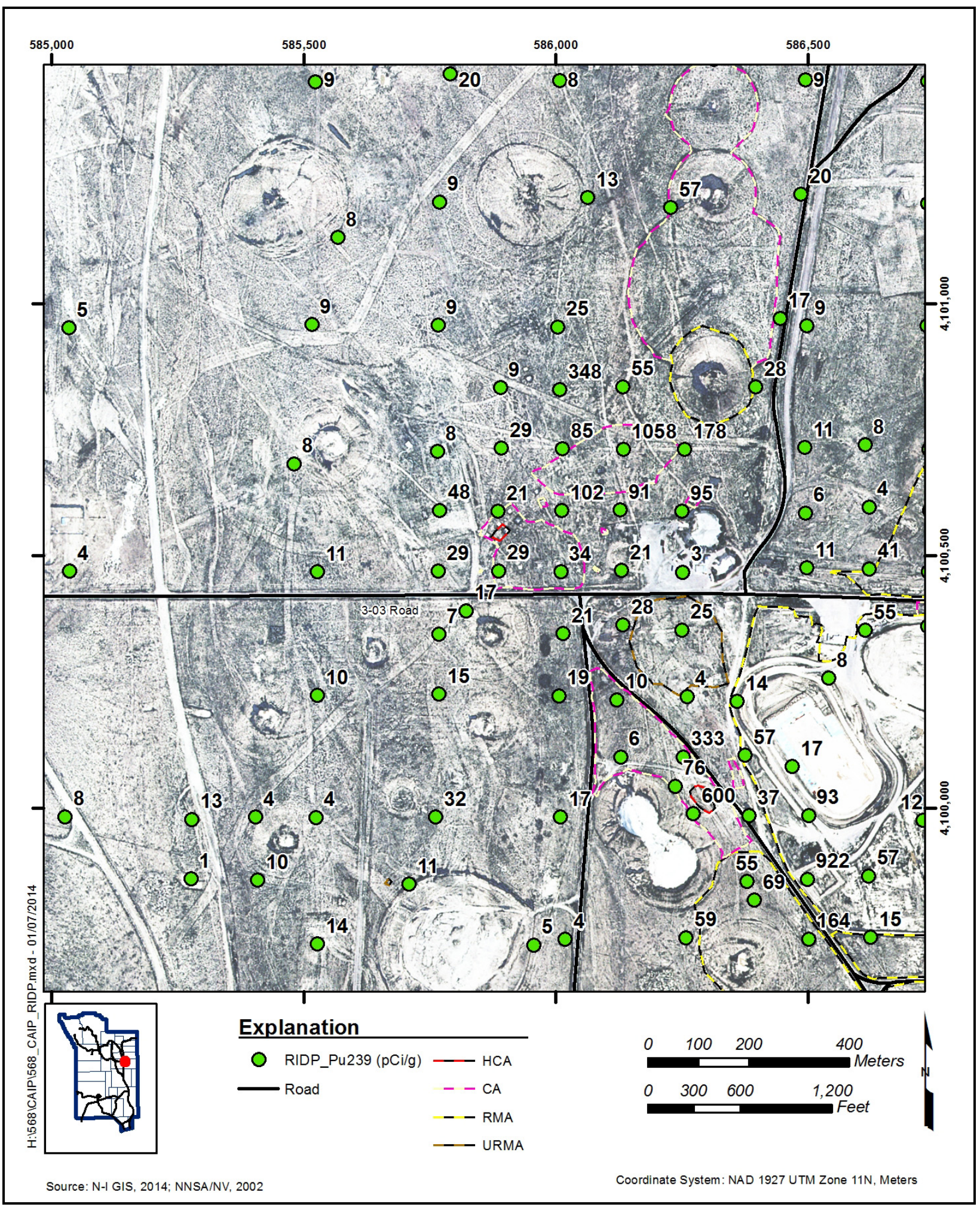

Figure 2-5

CAU 568 RIDP In Situ Data 


\subsubsection{CAU 568 Preliminary Investigation}

In 2012 and 2013, a preliminary field investigation was conducted in the CAU 568 area. This effort included visual surveys and TRSs. During the visual survey, photographs were taken and site conditions were noted. Scattered metal, concrete, debris piles containing soil and construction-related debris, lead items, and a transformer were identified during the visual survey. TRSs were primarily completed within the areas of radioactivity above background as identified by the 2012 aerial radiological survey (Stampahar, 2012). The appropriate radiological instruments were used to detect the suspected contaminants at a particular location. Specifically, the PRM-470 and FIDLER were used within areas where weapons-related tests were conducted, and the FIDLER was used for safety experiment locations. Figures 2-6 and 2-7 show the results of the TRSs conducted to date with the PRM-470 and FIDLER radiological instruments, respectively. For the PRM-470 TRS, nearly the entire surveyed area showed count data at or near background. For the FIDLER TRS, results of the surveyed area were consistent with the americium aerial radiological survey (Figure 2-4) but showed a higher resolution. These TRS signatures may be used in the biasing of sample locations or for defining the releases for Study Groups 1, 2, or 3.

\subsubsection{National Environmental Policy Act}

The Final Environmental Impact Statement for the Nevada Test Site and Off-Site Locations in the State of Nevada (DOE/NV, 1996) includes site investigation activities such as those proposed for CAU 568. In accordance with the NNSA/NFO National Environmental Policy Act (NEPA) Compliance Program, a NEPA checklist will be completed before beginning site investigation activities at CAU 568. This checklist requires NNSA/NFO activity personnel to evaluate their proposed activities against a list of potential impacts that include, but are not limited to, air quality, chemical use, waste generation, noise level, and land use. Completion of the checklist results in a determination of the appropriate level of NEPA documentation by the NNSA/NFO NEPA Compliance Officer. This will be accomplished before mobilization for the field investigation. 


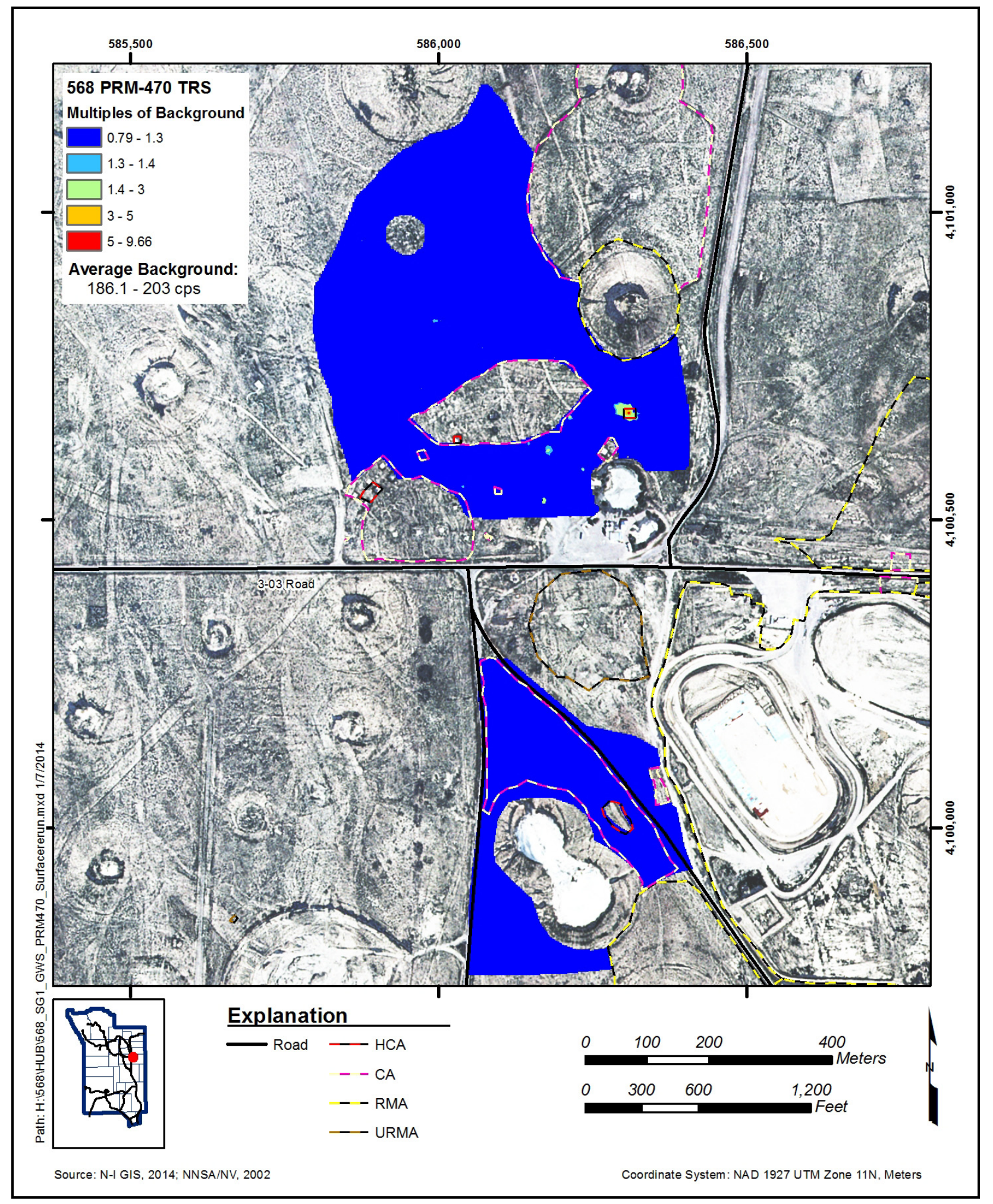

Figure 2-6

CAU 568 PRM-470 Survey Results 


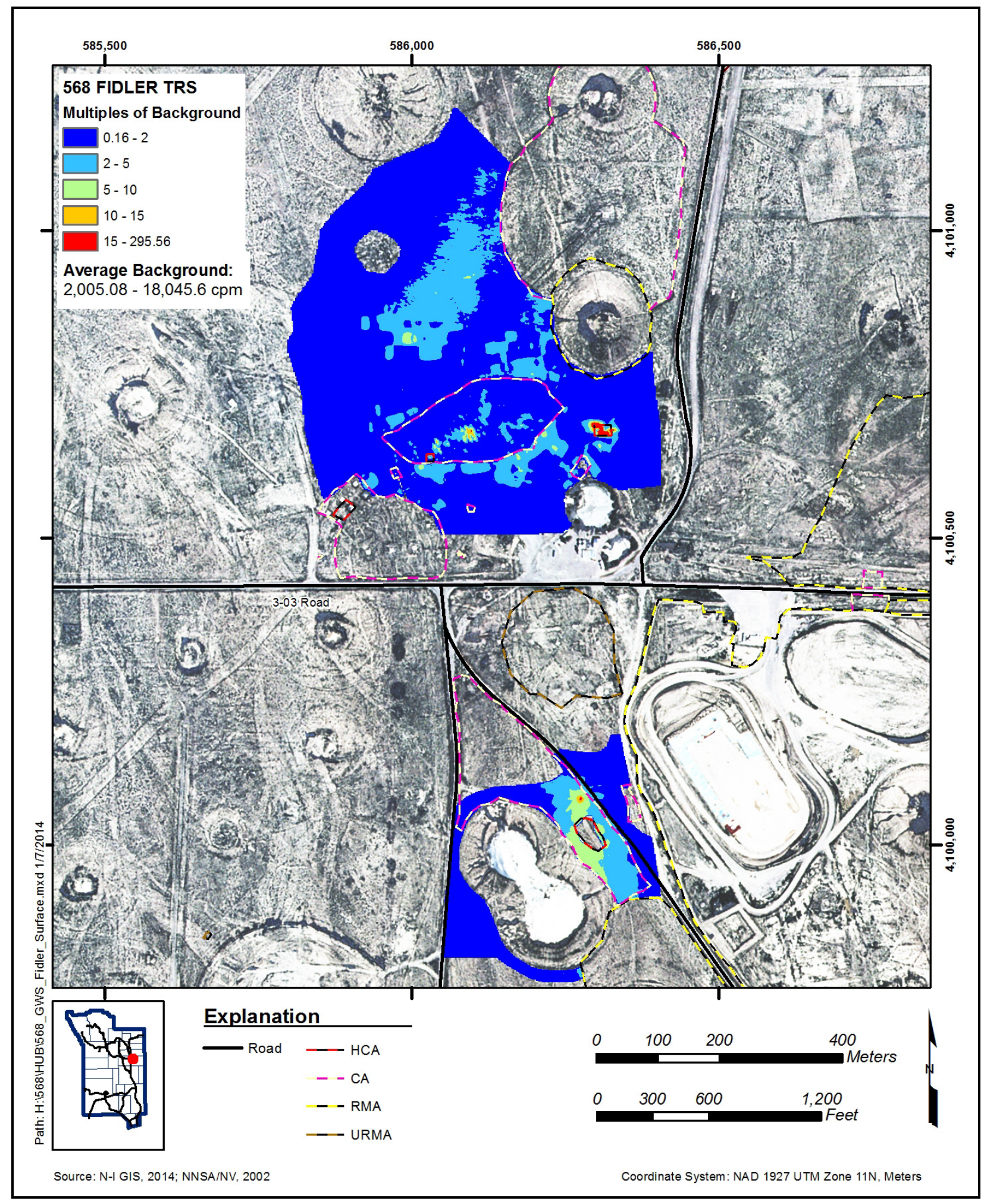

Figure 2-7

CAU 568 FIDLER Survey Results 


\subsection{Objectives}

This section presents an overview of the DQOs for CAU 568 and formulation of the CSM. Also presented is a summary listing of the contaminants of potential concern (COPCs), the preliminary action levels (PALs), and the process used to establish FALs. Additional details and figures depicting the CSM are located in Appendix A.

\subsection{Conceptual Site Model}

The CSM describes the most probable scenario for current conditions at each site and defines the assumptions that are the basis for identifying the future land use, contaminant sources, release mechanisms, migration pathways, exposure points, and exposure routes. The CSM was used to develop appropriate sampling strategies and data collection methods. The CSM was developed for CAU 568 using information from the physical setting, potential contaminant sources, release information, historical background information, knowledge from similar sites, and physical and chemical properties of the potentially affected media and COPCs. Figure A.2-1 depicts a representation of the conceptual pathways to receptors from CAU 568 sources. Figure A.2-2 depicts a graphical representation of the CSM. If evidence of contamination that is not consistent with the presented CSM is identified during investigation activities, the situation will be reviewed, the CSM will be revised, the DQOs will be reassessed, and a recommendation will be made as to how best to proceed. In such cases, decision makers listed in Section A.2.1 will be notified and given the opportunity to comment on and/or concur with the recommendation.

The following subsections discuss future land use and the identification of exposure pathways (i.e., combination of source, release, migration, exposure point, and receptor exposure route) for CAU 568.

\subsubsection{Land-Use and Exposure Scenarios}

The CAU 568 releases are located in the land-use zone described as "Nuclear and High Explosive Test Zone.” This area is designated for additional underground nuclear weapons tests and outdoor high-explosive tests. This zone includes compatible defense and nondefense research, development, 
and testing activities and is reserved for dynamic experiments, hydrodynamic tests, and underground nuclear weapons and weapons-effects tests (DOE/NV, 1996).

Exposure scenarios for the CAU 568 sites have been categorized into the following three types based on current and projected future land uses:

- Industrial Area. This scenario is based on industrial workers at established work facilities where the worker has a permanent assigned work area. This scenario assumes the worker will be on the site for an entire career (8 hours per day, 250 days per year, for 25 years). The industrial worker is assumed to spend 1/3 of the workday outdoors exposed to contaminated soil. The total effective dose (TED) calculated using this exposure scenario is the dose an industrial worker receives during 667 hours of annual exposure to site contaminants and is expressed in terms of millirem per Industrial Area year (mrem/IA-yr).

- Remote Work Area. This exposure scenario has the same basis as the Industrial Area scenario except that the industrial worker is not present at the work site for the entire year. This scenario assumes that the Remote Work Area has established work facilities where the worker regularly visits but is not a permanent assigned work area. A site worker under this scenario is assumed to be at the site for an equivalent of 8 hours per day, 42 days per year, for 25 years. The industrial worker is assumed to spend 1/3 of the workday outdoors exposed to contaminated soil. The TED calculated using this exposure scenario is the dose a remote area worker receives during 112 hours of annual exposure to site radioactivity and is expressed in terms of millirem per Remote Work Area Year (mrem/RW-yr).

- Occasional Use Area. This scenario is based on industrial workers at locations where there are no established work facilities in an area where the worker does not regularly visit but may occasionally use for short-term activities. This scenario assumes the worker will be on the site for an equivalent of 80 hours (or 10 days) per year for 5 years. The industrial worker is assumed to spend the entire workday outdoors exposed to contaminated soil. The TED calculated using this exposure scenario is the TED an industrial worker receives during 80 hours of annual exposure to site contaminants and is expressed in terms of millirem per Occasional Use Area year (mrem/OU-yr).

The CAU 568 land-use zone and exposure scenario are based on current and future land use at the NNSS. CAU 568 is a remote location without any site improvements and where no regular work is performed. There is still the possibility, however, that site workers could occupy these locations on an occasional and temporary basis such as a military exercise. Therefore, this site is classified as an Occasional Use Area. 


\subsubsection{Contaminant Sources}

Contaminant sources for CAU 568 CASs and the additional underground test releases are the releases identified in Section 2.4 of radiological contamination to the atmosphere and soil as a result of 15 shaft weapons-related tests, 10 shaft safety experiments, and 1 tower safety experiment. Other sources of potential contamination to surface or shallow subsurface soils include oil that was sprayed on the windrows to fix radiological contamination (REECo, 1959), and hazardous debris that is PSM (e.g., lead items and a transformer).

\subsubsection{Release Mechanisms}

The release mechanisms for the test releases consist of the underground detonation of nuclear or chemical explosives that vented to the atmosphere and deposited on the soil surface. For Chavez, the release mechanism consists of the atmospheric detonation of nuclear or chemical explosives that deposited contamination onto the soil surface. The release is expected to be radially distributed outward from the GZ or vent location with a bias toward the prevailing wind direction at the time of detonation (primarily to the north). Because many of the tests within CAU 568 were conducted in close proximity to one another, the surface deposition of contaminants from many of the tests resulted in plumes of overlapping contamination.

There is the potential that radionuclides originally distributed on the soil surface from these tests were translocated within drainages. This translocated soil is expected to be contained within drainages leading downgradient from the site.

After the safety experiments in the late 1950s, some of the contaminated surface soil was disturbed due to blading operations that placed the contaminated soil into windrows. The release mechanism for the windrows consists of the application of oils to the surface of the windrows. The release is expected to be limited to the extent of the windrows and may be located anywhere in the windrow area.

The release mechanism for the transformer at the site consists of the potential release of oil from the transformer onto the soil beneath and surrounding the transformer. For the lead items (lead batteries, lead sheets, a lead brick, and lead plate), the release mechanism consists of the potential release of oxidized lead into the soil beneath and around the lead item. 
For the four soil and debris piles, the release mechanism consists of the potential release of chemical or radiological contaminants to the soil beneath or surrounding the piles. The soil and debris piles are of unknown origin. They may not have originated from releases in the area and may have originated from other releases on the NNSS.

\subsubsection{Migration Pathways}

Surface migration pathways for CAU 568 include the lateral migration of potential contaminants across surface soils and accumulation in craters within the site, and vertical migration of potential contaminants into the subsurface soils. No major washes were identified at CAU 568; however, during recent precipitation events, a minor drainage was identified flowing from the CA on the north side of 3-03 Road into a nearby crater. Additional visual surveys will be conducted during the CAI to identify any other drainages at CAU 568. Drainage from the CAU 568 area flows toward and into Yucca Flat Dry Lake. Other migration pathways for contamination from the site include wind-borne material and material displaced from roads in the vicinity (e.g., moved during road maintenance). Contaminants also may have been disturbed through mechanical means due to windrow formation, subsequent underground testing activities, operations at the adjacent Area 3 mud plant, or construction and maintenance activities of nearby roads.

Migration is influenced by physical and chemical characteristics of the contaminants and media. Contaminant characteristics include, but are not limited to, solubility, density, and adsorption potential. Soil characteristics include permeability, porosity, water-holding capacity, sorting, chemical composition, and organic content. In general, contaminants with low solubility, high affinity for soil, and high density can be expected to be found relatively close to release points. Contaminants with high solubility, low affinity for soil, and low density can be expected to be found farther from release points. These factors affect the migration pathways and potential exposure points for the contaminants in the various media under consideration.

Infiltration and percolation of precipitation serve as driving forces for downward migration of contaminants. However, due to high PET (annual PET at the Area 3 RWMS has been estimated at 61.7 in. [Yucel, 2009]) and limited precipitation for this region (6.3 inches per year [in./yr] [Soule, 2006]), percolation of infiltrated precipitation at the NNSS does not provide a significant mechanism for vertical migration of contaminants to groundwater (DOE/NV, 1992). 
Subsurface migration pathways at CAU 568 are expected to be predominately vertical, although spills or leaks at the ground surface may also have limited lateral migration before infiltration. The depth of infiltration (shape of the subsurface contaminant plume) will be dependent upon the type, volume, and duration of the discharge as well as the presence of relatively impermeable layers that could modify vertical or lateral transport pathways, both on the ground surface (e.g., concrete) and in the subsurface (e.g., caliche layers). For surface contamination to reach the water table, the contaminants would have to be dissolved in infiltrating precipitation and then be transported through the vadose zone alluvium that extends the entire unsaturated thickness of $488 \mathrm{~m}$ at ER-3-2 (USGS, 2013).

Underground test craters have associated chimneys of disturbed geologic material that may provide a preferential pathway. Collection of stormwater in these craters also provides additional localized infiltration that will enhance contaminant migration rates.

The vertical penetration distance of infiltrating precipitation in 1,000 years would be the groundwater recharge rate (in millimeters per year $[\mathrm{mm} / \mathrm{yr}]$ ) divided by the volumetric moisture content (cubic centimeters per cubic centimeter) of the subsurface vadose zone alluvium times 1,000 years. The groundwater recharge rate in the vicinity of CAU 568 has been estimated to range from less than $0.1 \mathrm{~mm} / \mathrm{yr}$ to $2.5 \mathrm{~mm} / \mathrm{yr}$ based on regional infiltration studies (SNJV, 2006). The moisture content observed in the subsurface alluvium in shallow boreholes near the Area 3 RWMS indicates volumetric moisture contents in the range of 0.05 to 0.1 (Kwicklis et al., 2006). Based on these observations, penetration distances of infiltrating precipitation may be as much as $50 \mathrm{~m}$ in 1,000 years (using the maximum groundwater recharge rate of $2.5 \mathrm{~mm} / \mathrm{yr}$ and the minimum volumetric moisture content of 0.05).

\subsubsection{Exposure Points}

Exposure points, as identified in the CSM, are expected to be areas of surface contamination where visitors and site workers may come in contact with contaminated surface soil. Subsurface exposure points may exist if construction workers come in contact with contaminated soil during excavation activities. 


\subsubsection{Exposure Routes}

Exposure routes to site workers include ingestion and inhalation from disturbance of, or direct contact with, contaminated soil. Site workers may also be exposed to direct ionizing radiation by performing activities in proximity to radioactive materials.

\subsubsection{Additional Information}

Information concerning topography, geology, climatic conditions, hydrogeology, floodplains, and infrastructure at the CAU 568 sites is presented in Section 2.1 as it pertains to the investigation. This information has been addressed in the CSM and will be considered during the evaluation of CAAs, as applicable. Climatic and site conditions (e.g., surface and subsurface soil descriptions) as well as specific structure descriptions will be recorded during the CAI. If encountered, areas of erosion and deposition within drainages will be qualitatively evaluated to provide additional information on potential offsite migration of contamination.

\subsection{Contaminants of Potential Concern}

The COPCs for CAU 568 are defined as the contaminants reasonably expected at the site that could contribute to a dose or risk exceeding FALs. The contaminants that could reasonably be suspected to be present within the weapons-related test releases (Shrew, Wolverine, Platypus, Cognac, Chinchilla II, Stoat, Chinchilla, Armadillo, Haymaker, Solendon, Mink, Boomer, Funnel, Tuna, and Tendrac) include cesium (Cs)-137; europium (Eu)-152, -154, and -155; and uranium (U)-234 and -235. The contaminants that could reasonably be suspected to be present within safety experiment releases (Otero, San Juan, Chavez, Pascal-A, Colfax, Pascal-B, Luna, Bernalillo, Pascal-C, Valencia, and Chipmunk) include U-238; Pu-238, -239/240, and -241; and Am-241. Drainages at the site could contain any of the radionuclide COPCs from either weapons-related test releases or safety experiment releases.

The soil and debris piles are of unknown origin. Therefore, the COPCs include any radionuclide or chemical COPC commonly found at NNSS release sites. Lead is a COPC for the potential release from lead-acid batteries, lead plates, a lead brick, and a lead sheet. 
COPCs including PCBs, semivolatile organic compounds (SVOCs), and volatile organic compounds (VOCs) may be present within the windrow area of Study Group 1 from the oil that was sprayed on the windrows. A transformer was identified at the site, and COPCs for the potential release from the transformer may include PCBs, SVOCs, and VOCs. Although PCBs, SVOCs, and VOCs are not actually COPCs, they consist of a mixture of chemical contaminants generally classed as PCBs, SVOCs, or VOCs.

These COPCs were identified during the planning process through the review of site history, process knowledge, personal interviews, past investigation efforts (where available), and inferred activities associated with the CASs and other releases (including those that may be discovered during the investigation). Other specific COPCs (and subsequently the analyses requested) will be determined for discovered potential releases based on the nature of the potential release (e.g., hydrocarbon stain, debris pile).

Although not suspected to be present, analysis for other COPCs will be performed to eliminate the possibility of their presence due to an incomplete history of site testing operations as discussed in Section A.2.2.2. These COPCs were added to the analysis because they are either activation products in soil or may have been used as tracers and/or surrogates.

These COPCs (listed in Table A.2-2) will be reported by the analytical methods identified in Table A.2-3 for environmental samples taken at each of the sites. The analytes reported for each analytical method are listed in Table A.2-4.

\subsection{Preliminary Action Levels}

The PALs presented in this section are to be used for site screening purposes. They are not necessarily intended to be used as cleanup action levels or FALs. However, they are useful in screening out contaminants that are not present in sufficient concentrations to warrant further evaluation, thereby streamlining the consideration of remedial alternatives. The RBCA process used to establish FALs is described in the Soils RBCA document (NNSA/NFO, 2013). This process conforms with Nevada Administrative Code (NAC) 445A.227, which lists the requirements for sites with soil contamination (NAC, 2012a). For the evaluation of corrective actions, NAC 445A.22705 (NAC, 2012b) requires the use of ASTM International (ASTM) Method E1739 (ASTM, 1995) to "conduct an evaluation of the 
site, based on the risk it poses to public health and the environment, to determine the necessary remediation standards or to establish that corrective action is not necessary.” For the evaluation of corrective actions, the FALs are established as the necessary remedial standard.

This RBCA process, summarized in Figure 3-1, defines three tiers (or levels) of evaluation involving increasingly sophisticated analyses:

- Tier 1 evaluation. Sample results from source areas (highest concentrations) are compared to action levels based on generic (non-site-specific) conditions (i.e., the PALs established in the CAIP). The FALs may then be established as the Tier 1 action levels, or the FALs may be calculated using a Tier 2 evaluation.

- Tier 2 evaluation. Conducted by calculating Tier 2 action levels using site-specific information as inputs to the same or similar methodology used to calculate Tier 1 action levels. The Tier 2 action levels are then compared to individual sample results from reasonable points of exposure (as opposed to the source areas as is done in Tier 1) on a point-by-point basis. Results from total petroleum hydrocarbons (TPH) analyses will not be used for risk-based decisions under Tier 2 or Tier 3. Rather, the individual chemical constituents of diesel reported from VOC and SVOC analyses will be compared to the action levels.

- Tier 3 evaluation. Conducted by calculating Tier 3 action levels on the basis of more sophisticated risk analyses using methodologies described in Method E1739 that consider site-, pathway-, and receptor-specific parameters.

This RBCA process includes a provision for conducting an interim remedial action if necessary and appropriate. The decision to conduct an interim action may be made at any time during the investigation and at any level (tier) of analysis. Concurrence of the decision makers listed in Section A.2.1 will be obtained before any interim action is implemented. Evaluation of DQO decisions will be based on conditions at the site after any interim actions are completed. Any interim actions conducted will be reported in the investigation report.

If, after implementation of corrective actions, radioactive contamination remains in place that is less than the site-specific exposure scenario based FAL but exceeds 25 millirem per year (mrem/yr) based on the Industrial Area exposure scenario, an administrative use restriction (UR) will be implemented to prevent future industrial use of the area. For this reason, contamination at all sites will be evaluated against industrial exposure scenario based PALs and site-specific exposure scenario based FALs. The 


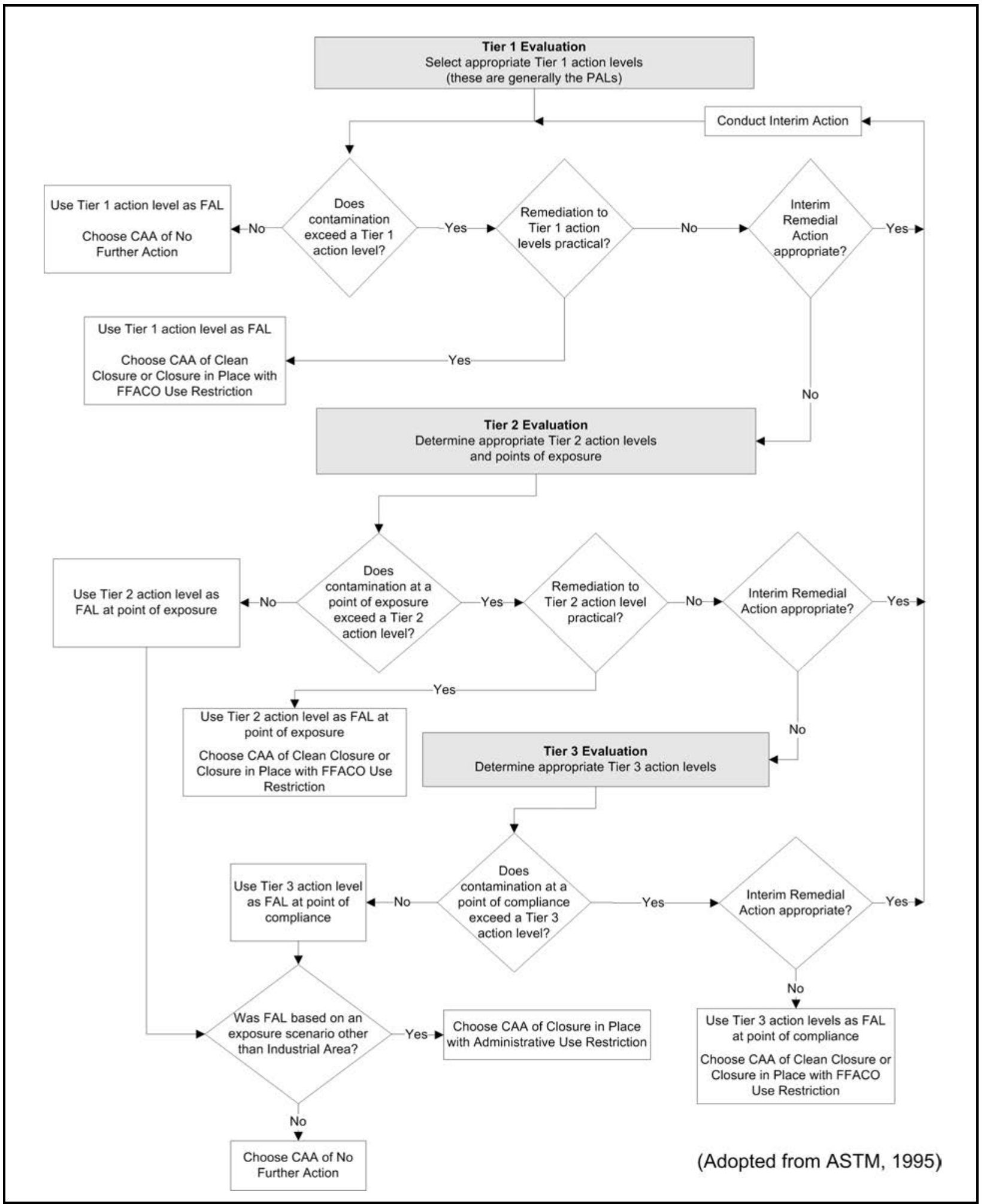

Figure 3-1

RBCA Decision Process 
FALs (along with the basis for their selection) will be proposed in the investigation report, where they will be compared to laboratory results in the evaluation of potential corrective actions.

\subsubsection{Chemical PALs}

Except as noted herein, the chemical PALs are defined as the U.S. Environmental Protection Agency (EPA) Region 9 Regional Screening Levels for chemical contaminants in industrial soils (EPA, 2013). Background concentrations for RCRA metals will be used instead of screening levels when natural background concentrations exceed the screening level, as is often the case with arsenic on the NNSS. Background is considered the mean plus two standard deviations of the mean for sediment samples collected by the Nevada Bureau of Mines and Geology throughout the Nevada Test

and Training Range (formerly the Nellis Air Force Range) (NBMG, 1998; Moore, 1999). For detected chemical COPCs without established screening levels, the protocol used by EPA Region 9 in establishing screening levels (or similar) will be used to establish PALs. If used, this process will be documented in the investigation report.

\subsubsection{Radionuclide PALs}

The PAL for radioactive contaminants is a TED of 25 mrem/yr, based upon the Industrial Area exposure scenario. The Industrial Area exposure scenario is described in Soils RBCA document (NNSA/NFO, 2013). The TED is calculated as the sum of external dose and internal dose. External dose is determined using TLD measurements. Internal dose is determined by comparing analytical results from soil samples to residual radioactive material guidelines (RRMGs) that were established using the RESRAD computer code (Yu et al., 2001). RRMGs are radionuclide-specific values for radioactivity in surface soils. The RRMG is the value, in picocuries per gram of surface soil, for a particular radionuclide that would result in an internal dose of $25 \mathrm{mrem} / \mathrm{yr}$ to a receptor (under the appropriate exposure scenario) independent of any other radionuclide (assuming that no other radionuclides contribute dose). The RRMGs are presented in the Soils RBCA document.

In the RESRAD calculation, several input parameter values are not specified so that site-specific information can be used. The default and site-specific input parameter values used in the RESRAD calculation of RRMGs for each exposure scenario are listed in the Soils RBCA document (NNSA/NFO, 2013). 


\subsection{DQO Process Discussion}

This section contains a summary of the DQO process that is presented in Appendix A. The DQO process is a strategic planning approach based on the scientific method that is designed to ensure that the data collected will provide sufficient and reliable information to identify, evaluate, and technically defend the recommendation of viable corrective actions (e.g., no further action, clean closure, or closure in place).

As presented in Section 4.1, it is assumed that TED within the DCBs (i.e., HCAs at Chavez and San Juan, soil/debris pile posted as an HCA, and subsurface soils at the shaft safety experiments that vented) exceed the FAL. Figure 3-2 shows the DCBs associated with CAU 568. For these areas, the DQO decisions are resolved and corrective action is required. DQO decisions will be resolved for the areas outside the DCBs.

As presented in Section 1.1.2, the DQOs address different potential contaminant release types that have been organized into study groups that will be investigated using different sampling techniques. Therefore, discussions related to the sample groups are presented separately.

The DQO strategy for CAU 568 was developed at a meeting on August 27, 2013. DQOs were developed to identify data needs, clearly define the intended use of the environmental data, and to design a data collection program that will satisfy these purposes. During the DQO discussions for this CAU, the informational inputs or data needs to resolve problem statements and decision statements were documented.

The problem statement for CAU 568 is as follows: "Existing information on the nature and extent of potential contamination is insufficient to evaluate and recommend CAAs for the CASs in CAU 568.” To address this problem statement, resolution of the following decision statements is required:

- Decision I. “Is any COC associated with the release present in environmental media?” For judgmental sampling decisions, any contaminant that is present at concentrations exceeding its corresponding FAL will be defined as a COC. For probabilistic sampling decisions, any contaminant for which the 95 percent UCL of the mean exceeds its corresponding FAL will be defined as a COC. A COC may also be defined as a contaminant that, in combination with other like contaminants, is determined to jointly pose an unacceptable risk based on a multiple constituent analysis (NNSA/NFO, 2013). 


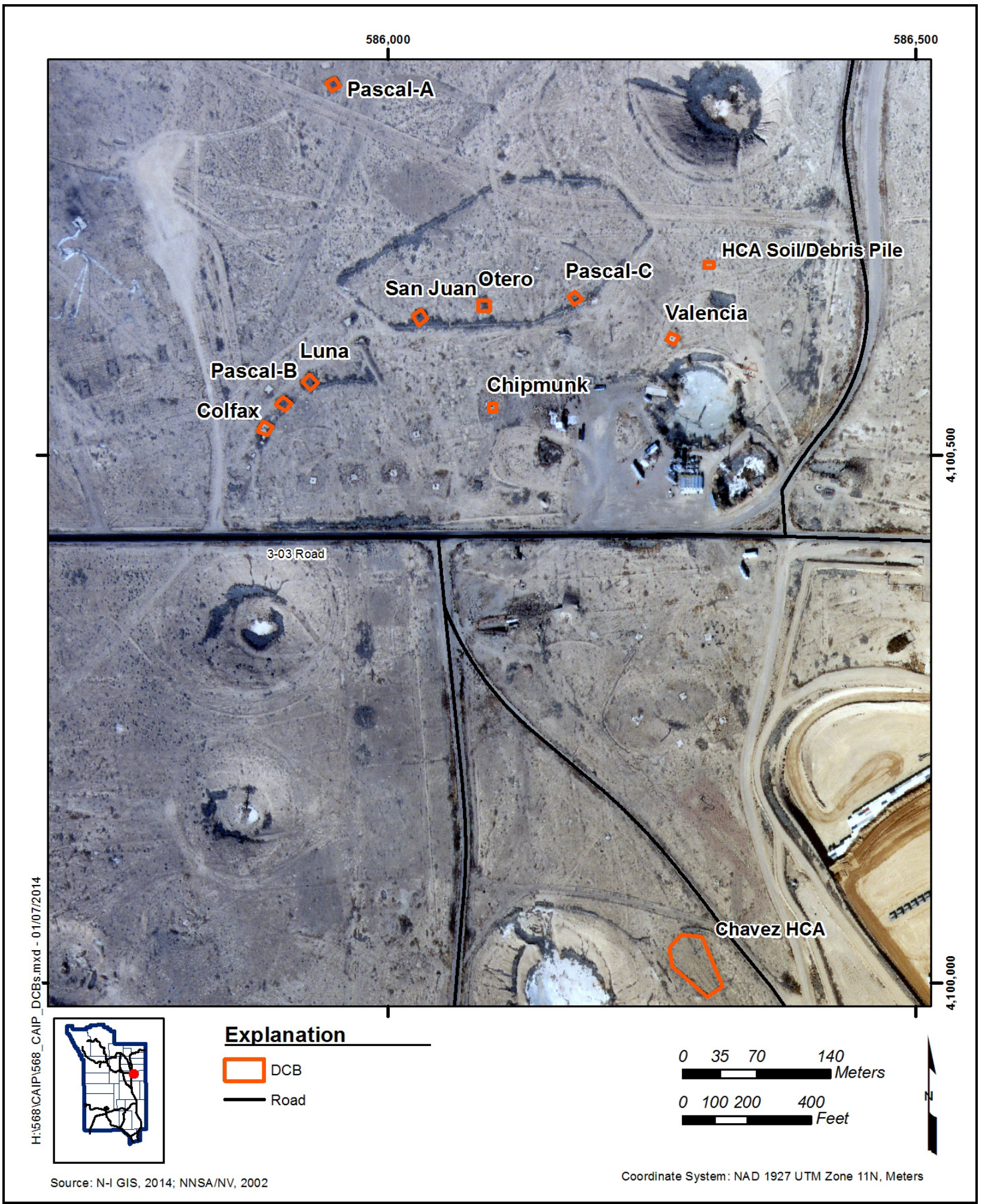

Figure 3-2

CAU 568 DCBs 
- Decision II. "Is sufficient information available to evaluate potential CAAs?" Sufficient information is defined to include to following:

- The lateral and vertical extent of COC contamination

- The information needed to determine potential remediation waste types

- The information needed to evaluate the feasibility of remediation alternatives

A corrective action will be determined for any release site containing a COC. The evaluation of the need for corrective action will include the potential for wastes that are present at the site to contain contaminants that, if released, could cause the surrounding environmental media to contain COCs. Such a waste will be evaluated using the PSM criteria listed in the Soils RBCA document (NNSA/NFO, 2013) to determine the need for corrective action.

The informational inputs and data needs to resolve the problem statement and the decision statements were generated as part of the DQO process for this CAU and are documented in Appendix A. The information necessary to resolve the DQO decisions will be generated for each CAU 568 CAS by collecting and analyzing samples generated during a field investigation. The presence of a COC will be determined by collecting and analyzing samples from locations determined most likely to contain a COC (based on the presence of a biasing factor).

The judgmental sampling design will be used to collect samples from biased locations. Results from these locations can only be used to infer a characteristic (e.g., average concentration) of the sampled location (i.e., not an area). The characteristic normally used to define contamination at a location is the contaminant concentration or dose from a single sample or the average if more than one sample is collected from the location. When the sample is collected from the location of the greatest degree of the selected biasing factor, this represents the maximum dose or contaminant concentration at the release site.

A probabilistic sampling design will be used to collect samples from unbiased locations within an area that can be readily defined by distinct characteristics where the assumed distribution of contamination is relatively uniform. Results from these locations will be used to infer a characteristic representative of the sampled area as a whole (i.e., representing the average of the entire area, not the maximum at any one location). The characteristic normally used to define contamination within an area is the 95 percent UCL of the mean concentration or dose. 
Protection against false-negative decision errors are provided by the following:

- Judgmental sampling when contamination concentrations or dose levels from locations of the greatest degree of the selected biasing factor are used to make decisions for a larger area (e.g., a release site).

- Probabilistic sampling when the 95 percent UCL of the mean concentration or dose is used to make decisions for the defined sampling area.

Decisions are even more conservative when probabilistic results (i.e., 95 percent UCL) from biased locations are used to make a decision on the presence of COCs for the entire release site. This is typically the case when the 95 percent UCL of contamination at a sample plot located in the area of the highest radiation survey values are used to resolve the decision on the presence of COCs (i.e., Decision I).

For the Study Groups 1, 2, 3, and 5 scenario, it is unknown whether COCs are present outside the DCBs and Decision I sampling will be conducted. If COCs are identified, Decision II must be resolved for Study Groups 1, 2, and 5 at CAU 568. If COCs are identified for Study Group 3, Decision II planning will be conducted with the stakeholders.

For the Study Group 4 scenario, Decision I samples will be submitted to analytical laboratories to determine the presence of COCs. The specific analyses for samples from Study Group 4 will be selected dependent upon the type and nature of the identified release. Decision II samples for both release scenarios will be submitted as necessary to define the extent of unbounded COCs. In addition, samples will be submitted for analyses, as needed, to support waste management or health and safety decisions.

For the laboratory data, the data quality indicators (DQIs) of precision, accuracy, representativeness, comparability, completeness, and sensitivity needed to satisfy DQO requirements are discussed in the Soils QAP (NNSA/NSO, 2012). Laboratory data will be assessed in the investigation report to confirm or refute the CSM, and determine whether the DQO data needs were met. 


\subsection{Field Investigation}

This section contains a description of the activities to be conducted to gather and document information from the CAU 568 field investigation.

\subsection{Technical Approach}

The information necessary to satisfy the DQO data needs will be generated for CAU 568 by collecting and analyzing samples generated during a field investigation. However, the investigation will not include the areas within the CAU that contain removable radioactivity that exceeds the criteria for establishing an HCA as contamination exceeding FALs is assumed to be present within these areas and requires corrective action. For the HCAs, this assumption is based on the potential for a receptor in these areas to inhale, ingest, and transport this removable contamination. The investigation does not include the subsurface contamination within test chimneys of safety experiments that had a release of radioactivity to the soil surface. These locations are assumed to contain contaminants exceeding FALs in the subsurface and corrective actions are required. DCBs were established for the HCAs at Chavez and San Juan, the soil/debris pile HCA, and the subsurface contamination within the test chimneys meeting the criteria discussed above. These DCBs are shown on Figure 3-2. For the area outside the DCBs, information will be generated during a site investigation to resolve DQO decisions.

The presence and nature of contamination decision (Decision I) will be a judgmental decision determined using sample results from biased locations under a judgmental sampling design. For sample plot locations, each Decision I sample plot will generate a TED value for the judgmental decision that represents the population of doses within the 100-square-meter area of the sample plot. This representative TED value will be determined using probabilistic sampling design to generate a 95 percent UCL of the average TED within the plot area. For grab sample locations, DQO decisions will be based on a direct comparison of sample results to the FAL.

The extent of COC contamination portion of Decision II will be resolved using one of the methods listed in Section A.4.1. The extent of radiological COC contamination decision (Decision II) will be a probabilistic decision determined using Method 1 by correlating TED and radiological survey values 
as described in the Soils RBCA document (NNSA/NFO, 2013). This method will only be used if the correlation between TED and the survey values has a coefficient of determination $\left(\mathrm{r}^{2}\right)$ greater than 0.8. The statistical relationship among the correlated values can then be used to estimate a 95 percent lower confidence limit (LCL) of the correlation. The radiation survey value that intersects the LCL of the correlation at the TED value of $25 \mathrm{mrem} / \mathrm{yr}$ (under the appropriate exposure scenario) will be used as the radiation survey isopleth that defines the extent of contamination.

A correlation for each radiation survey will be established to identify the radiation survey that has the best correlation to TED values. This correlation will be used to establish a radiation survey value corresponding to the FAL when establishing a corrective action boundary or the PAL when establishing an administrative UR boundary.

The TED will be calculated using the methodologies described in the Soils RBCA document (NNSA/NFO, 2013).

Modifications to the investigative strategy may be required should unexpected field conditions be encountered at any site. Significant modifications must be justified and documented before implementation. If an unexpected condition indicates that conditions are significantly different from the CSM, the activity will be rescoped and the identified decision makers will be notified.

\subsection{Field Activities}

Field activities at CAU 568 include site preparation, sample location selection, sample collection, and demobilization.

\subsubsection{Site Preparation Activities}

Site preparation activities to be conducted before the start of environmental sampling may include relocating or removing surface debris, equipment, and structures; constructing hazardous waste accumulation areas (HWAAs) and site exclusion zones; providing sanitary facilities; constructing decontamination facilities; and moving staged equipment. 
Before mobilization for collecting investigation samples, the following preparatory activities will also be conducted:

- Perform radiological surveys to identify bias used in selecting sample locations.

- Install activity-specific environmental monitoring TLDs (see Section 4.2.3 for additional information).

- Perform visual surveys at all sites within CAU 568 to identify any biasing factors (e.g., staining, disturbance of native soils) that may be an indication of potential contamination.

\subsubsection{Sample Location Selection}

Rationale for selecting areas for sampling is discussed in the following subsections. For all investigations, if a spatial boundary is reached, the CSM is shown to be inadequate, or the Site Supervisor determines that extent sampling needs to be reevaluated, then work will be temporarily suspended, NDEP will be notified, and the investigation strategy will be reevaluated.

The sampling strategy and the estimated locations of biased samples are presented in Appendix A and summarized in the following subsections. The number, location, and spacing of step-outs may be modified as warranted by site conditions to achieve DQO criteria stipulated in Appendix A. Where sampling locations are modified, the justification for these modifications will be documented in the investigation report.

As presented in Section 4.1, it is assumed that corrective action is required within the DCBs. Therefore, sampling of these areas is not necessary.

\subsubsection{Study Group 1: Releases within a Defined Radiological Survey Signature}

For each release within a defined radiological survey signature, Decision I will be evaluated by measuring TED within a sample plot established within the area of the highest radiological values. The highest radiological values will be determined from the applicable TRS conducted with a handheld instrument and/or the 2012 flyover survey (Stampahar, 2012). This will be done in an effort to find the location of the highest TED. Based on the results of these surveys or the additional TRSs that have yet to be conducted, Decision I sample plots at Study Group 1 will be placed at the locations 
of the highest readings from the aerial survey or TRS. If the 95 percent UCL of the TED at the Decision I sample plots associated with each defined radiological survey signature exceeds 25 mrem/IA-yr, a corrective action will be required and Decision II will be resolved. Information for Decision II will be obtained by establishing a minimum of three Decision II sample plot locations judgmentally along vectors (minimum of two vectors total) that are approximately normal to the appropriate radiation survey isopleths. See Figures A.8-1 and A.8-2 for the locations of sample plots. Sample plot locations will be adjusted based on additional TRSs conducted during the CAI.

Within a portion of the Study Group 1 area, historical documentation shows that windrows were created. Although the windrows are no longer present at the site, there is a potential for radionuclides associated with atmospheric releases to be present at depths greater than $5 \mathrm{~cm}$ within this area. In order to characterize the subsurface soil, two of the Decision II sample plots will be located within this windrow area and investigated for the presence of subsurface contamination. See Figure A.8-1 for the locations of the sample plots within the windrow area that will be investigated for subsurface contamination.

\subsubsection{Study Group 2: Releases Located within a Crater or Potential Crater Area That Cannot Be Entered}

For Study Group 2 at CAU 568, TRSs will be conducted around each identified potential crater/crater area with a test release to determine whether any radioactivity above background is present originating from within the potential crater area/crater area. If a pattern of radioactivity is detected around the crater, it will be assumed that radioactivity within the crater exceeds FALs and will require corrective action. If radioactivity is detected above background outside the crater, sample locations will be located in accordance with the sampling approach for Study Group 1 (Section 4.2.2.1). If radioactivity is not detected above background, no sample locations will be established.

\subsubsection{Study Group 3: Releases with No Radiological Survey Signature That Can Be Entered}

For each test release with no radiological survey signature, Decision I will be evaluated by measuring TED within a grab sample location established within either the location of the highest radiological values as determined from the applicable TRS (indicating the area where the maximum dose would most likely be located) or the nearest feasible location nearest to GZ. This will be done in an effort to 
find the location of the highest TED. Additional TRSs will be conducted during the CAI to determine the sample locations for Study Group 3. If the results of the Decision I samples at Study Group 3 indicate contamination present that exceeds the FALs, then a Decision II sampling strategy will be developed and agreed upon by the stakeholders.

\subsubsection{Study Group 4: Spills and Debris}

Decision I evaluation for this study group will be a judgmental sampling approach and will be based on the feature being investigated to determine the presence of a COC. Biasing factors such as stains, radiological survey results, and wastes suspected of containing hazardous or radiological components will be used to select the most appropriate samples from a particular location for collection and analysis. For PSM, a sample will be collected from below the debris or spill. Where COCs have been confirmed based on validated laboratory analytical results, Decision II sampling will be conducted to define the extent of contamination using one of the methods described in Section A.4.1. The locations of the debris items identified during the visual surveys are shown in Figure A.8-4. Additional items may be identified during the CAI. If additional items are identified, they will be investigated appropriately within this study group.

If a COC is present at a PSM location, the COC may be removed under an interim action. If an interim action removal is conducted, verification samples will be collected at the locations where the CSM was removed to demonstrate that all soils exceeding the FAL were removed.

\subsubsection{Study Group 5: Drainages}

During a recent precipitation event, a minor drainage was identified that travels downgradient from the CA at CAS 03-23-26, across 3-03 Road, and into the Agouti test crater. This drainage (location shown on Figure A.8-4), and any others identified during the CAI, will be visually and radiologically surveyed. The visual survey will be conducted to identify sediment accumulation areas. If any are identified, a Decision I sample location will be established at the center of the nearest two downgradient sediment accumulation areas that could be impacted by radionuclides associated with the CAU 568 releases. A radiological survey will be conducted to identify elevated readings where additional judgmental sample locations may be selected. 
Additional sedimentation areas will be sampled until at least two consecutive sedimentation areas are found that do not contain a COC. Any drainage contamination found to enter a crater will be handled under the subsidence crater strategy in the Soils RBCA document (NNSA/NFO, 2013).

\subsubsection{Sample Collection}

The CAU 568 sampling program will consist of the following activities:

- $\quad$ Collect soil samples from locations as described in Section 4.2.2.

- Collect required QC samples.

- Collect waste management samples as necessary.

- Collect external dose measurements by hanging TLDs at the appropriate sample locations or extent locations.

- $\quad$ Record Global Positioning System (GPS) coordinates for each environmental sample location.

To determine internal dose for the Study Group 1 scenario, a probabilistic sampling approach will be implemented for collecting composite samples within the sample plots. Each composite sample will consist of soil collected from the surface to a depth of $5 \mathrm{~cm}$ at nine randomly located subsample locations within the plot. For each composite sample, the first location will be selected randomly; the remaining eight subsample locations will be established on a systematic triangular grid (see Section A.8.0). External dose will be sampled from a TLD installed the approximate center of the sample plot at a height of $1 \mathrm{~m}$ and be left in place for approximately 2,000 hours (equivalent to an annual industrial worker exposure).

For the evaluation of subsurface soil contamination within the windrow area at Study Group 1, one judgmental location at the center of each sample plot will be screened in 5-cm depth intervals until native material is encountered using the appropriate tool or equipment. Each interval will be screened with an alpha/beta detection meter. If the field-screening result (FSR) is greater than the daily field-screening level (FSL) and 20 percent higher than the surface sample, both the surface sample and the depth interval with the highest FSR will be submitted for analysis. If the FSL is not exceeded in any depth sample, only the surface sample will be submitted for analysis. If a COC is present in 
any depth interval sample, the entire windrow area (as discussed in Section 2.2.7) will be assumed to contain the COC and will require corrective action.

For Study Group 5, the judgmental samples locations will be sampled similar to the windrow areas of Study Group 1, except that each sediment accumulation area identified for sampling will be screened in 5- or 10 -cm depth intervals.

For Study Group 3, only judgmental surface grab samples will be collected from a depth of 0 to 5 cm bgs.

For Study Group 4, judgmental surface grab samples will be collected at an interval of 0 to $5 \mathrm{~cm}$ bgs. If biasing factors are present in soils below locations where Decision I samples were collected, subsurface soil samples will also be collected, as appropriate, using the appropriate tool or equipment. If the COPCs are radionuclides only, subsurface screening as described above for Study Group 1 will apply.

For Study Group 2, information necessary to resolve Decision I will be collected by performing a radiation survey around the crater perimeter. If radioactivity associated with the crater is detected above background within this study group through the conduction of TRSs, sample plots will be established and sampled under the approach for Study Group 1.

\subsubsection{Sample Management}

The laboratory requirements (i.e., minimum detectable concentrations [MDCs], precision, and accuracy) to be used when analyzing the COPCs are presented in the Soils QAP (NNSA/NSO, 2012). The analytical program is presented in Table A.2-3. All sampling activities and QC requirements for field and laboratory environmental sampling will be conducted in compliance with the Soils QAP.

\subsection{Site Restoration}

Upon completion of CAI and waste management activities, the following actions will be implemented before closure of the site Real Estate/Operations Permit (REOP):

- All equipment, wastes, debris, and materials associated with the CAI will be removed from the site. 
- All CAI-related signage and fencing (unless part of a corrective action) will be removed from the site.

- Site will be inspected to ensure restoration activities have been completed. 


\subsection{Waste Management}

Waste generated during the CAU 568 field investigation will be managed in accordance with all applicable DOE orders, federal and state regulations, and agreements and permits between DOE and NDEP. Wastes will be characterized based on these regulations using process knowledge, FSRs, and analytical results from investigation and waste samples. Waste types that may be generated during the CAI include industrial, hazardous, hydrocarbon, TSCA regulated (e.g., PCBs, asbestos), low-level radioactive, or mixed wastes.

Disposable sampling equipment, personal protective equipment (PPE), and rinsate are considered potentially contaminated waste only by virtue of contact with potentially contaminated soil or potentially contaminated debris (e.g., lead). These wastes may be characterized based on associated environmental sample results, waste characterization results, FSRs, or process knowledge.

Chemicals were not known to be used or present at this CAU in a manner that would generate RCRA-listed hazardous waste; therefore, wastes will be characterized based on their chemical characteristics. If RCRA-characteristic wastes are generated, they will be managed and disposed of in accordance with applicable waste requirements.

Conservative estimates of total waste contaminant concentrations may be made based on the mass of the waste, the amount of contaminated soil contained in the waste, and the maximum concentration of contamination found in the soil.

The following subsections discuss how the field investigation will be conducted to minimize the generation of waste, what waste streams are expected to be generated, and how IDW will be managed.

\subsection{Waste Minimization}

The CAI will be conducted in a manner that will minimize the generation of wastes using process knowledge, segregation, visual examination, and/or field screening (e.g., radiological survey and swipe results) to avoid cross-contaminating uncontaminated soil or uncontaminated IDW that would otherwise be characterized and disposed of as industrial waste. As appropriate, soil and debris will be 
returned to their original location. To limit unnecessary generation of hazardous or mixed waste, hazardous materials will not be used during the CAI. Other waste minimization practices will include, as appropriate, avoiding contact with contaminated materials, performing dry decontamination or wet decontamination over source locations, and carefully segregating waste streams.

\subsection{Potential Waste Streams}

The following is a list of common waste streams that may be generated during the field investigation and that may require management and disposal:

- Disposable sampling equipment and field screening waste

- PPE

- Soil

- $\quad$ Surface debris (e.g., lead items, concrete, wood, batteries, scrap metal)

- Decontamination rinsate

\subsection{IDW Management}

The onsite management of IDW will be determined based on regulations associated with the particular waste type (e.g., industrial, low-level), or the combination of waste types. The following subsections describe how specific waste types will be managed.

\subsubsection{Industrial Waste}

Industrial solid waste, if generated, will be collected, managed, and disposed of in accordance with the solid waste regulations and the permits for operation of the NNSS Solid Waste Disposal Sites. The most commonly generated industrial solid waste includes disposable sampling equipment and PPE that will be collected in plastic bags, and managed in accordance with requirements.

\subsubsection{Hazardous Waste}

Suspected hazardous waste, if generated, will be containerized and managed in waste accumulation areas in accordance with 40 Code of Federal Regulations (CFR) 262.34 (CFR, 2013a). It is anticipated that a satellite accumulation area will be established due to the small volumes of lead-contaminated items (i.e., lead-acid batteries) present at the site. 


\subsubsection{Hydrocarbon Waste}

Suspected hydrocarbon solid waste, if generated, will be managed on site in a drum or other appropriate container until fully characterized and in accordance with the State of Nevada regulations (NDEP, 2006).

\subsubsection{Polychlorinated Biphenyls}

The management of PCBs is governed by TSCA and its implementing regulations at 40 CFR 761 (CFR, 2013b), and agreements between EPA and NDEP. PCB contamination may be found as a sole contaminant or in combination with any of the types of waste discussed in this document. For example, PCBs may be a co-contaminant in soil that contains a RCRA “characteristic” waste (PCB/hazardous waste), or in soil that contains radioactive wastes (PCB/radioactive waste), or even in mixed waste (PCB/radioactive/hazardous waste). IDW will initially be evaluated using analytical results for soil samples from the CAI. If any type of PCB waste is generated, it will be managed in accordance with 40 CFR 761 (CFR, 2013b) as well as State of Nevada requirements (NAC, 2012b), guidance, and agreements with NNSA/NFO.

\subsubsection{Low-Level Waste}

Low-level radioactive waste, if generated, will be managed in accordance with the contractor-specific waste certification program plan, DOE orders, and the requirements of the current version of the Nevada National Security Site Waste Acceptance Criteria (NNSA/NSO, 2013). Potential radioactive waste containers will be staged and managed at a designated radioactive material area (RMA).

\subsubsection{Mixed Low-Level Waste}

Mixed waste, if generated, will be managed in accordance with the RCRA requirements (CFR, 2013b), agreements between NNSA/NFO and the State of Nevada, and DOE requirements for radioactive waste. Waste characterized as mixed will not be stored for a period of time that exceeds the RCRA requirements unless subject to agreements between NNSA/NFO and the State of Nevada. The mixed waste must be transported via an approved hazardous waste/radioactive waste transporter to the NNSS transuranic waste storage pad for storage pending treatment or disposal. 


\subsection{Quality Assurance/Quality Control}

The overall objective of the characterization activities described in this CAIP is to collect accurate and defensible data to support the selection and implementation of a closure alternative for CASs in CAU 568. All characterization activities, including those related to TLD measurements, will be conducted in accordance with the Soils QAP (NNSA/NSO, 2012) and the Soils RBCA document (NNSA/NFO, 2013), which define rigorous data quality requirements. Sections 6.1 and 6.2 discuss the collection of required QC samples in the field and QA requirements for the laboratory analysis of soil samples.

\subsection{QC Sampling Activities}

Field QC samples will be collected in accordance with established procedures. Field QC samples are collected and analyzed to aid in determining the validity of environmental sample results. The number of required QC samples depends on the types and number of environmental samples collected. As determined in the DQO process, the minimum frequency of collecting and analyzing QC samples for this investigation is as follows:

\section{- Radiological samples}

- Field duplicates for grab samples (1 per 20 environmental samples)

\section{- Chemical samples (if collected)}

- Field duplicates for grab samples (1 per 20 environmental samples)

- Trip blanks (1 per sample cooler containing VOC environmental samples)

Additional QC samples may be submitted based on site conditions at the discretion of the Task Manager or Site Supervisor. Field QC samples must be analyzed using the same analytical procedures implemented for associated environmental samples. Additional details regarding field QC samples are available in the Soils QAP (NNSA/NSO, 2012). 


\subsection{Laboratory/Analytical Quality Assurance}

As stated in the DQOs (see Appendix A) and in the Soils QAP (NNSA/NSO, 2012), data used for making DQO decisions will be evaluated for data quality. The Soils QAP defines and establishes data quality criteria that are evaluated in three defined steps:

1. Data Verification

2. Data Validation

3. Data Quality Assessment

Data verification will include an evaluation of all chemical and radiological laboratory data for data quality in accordance with company-specific procedures. The data will be reviewed to evaluate the completeness, correctness, and conformance of each dataset. This verification will include a review of sample collection, handling and transfer, and documentation associated with sampling activities.

Data validation must be performed on a portion of the environmental sample results to determine the analytical quality of a dataset. Data validation criteria must be based upon the DQOs and the intended use of the data. Validation should include an evaluation of method and contract compliance, data calculations, QC and calibration verifications, raw data, and data generation methods. Validation can include qualifying data that may restrict or limit data use. The data validation includes an evaluation of the following DQI criteria:

1. Precision

2. Accuracy/bias

3. Representativeness

4. Comparability

5. Completeness

6. Sensitivity.

Data that do not meet the DQI criteria must be evaluated for usability in the investigation report.

A data quality assessment (DQA) must be performed to determine whether the data meet the DQO requirements of the investigation and the performance criteria for the DQIs. The DQA considers how the data relate to decisions to be made, the intended use of the data, and whether data are suitable for making those decisions. The results of this assessment will be documented in the investigation report. If the DQOs were not met, corrective actions will be evaluated, selected, and implemented (e.g., refine CSM, or resample to fill data gaps). 


\subsection{Duration and Records Availability}

\subsection{Duration}

Field and analytical activities will require approximately 160 days to complete.

\subsection{Records Availability}

Historical information and documents referenced in this plan are retained in the NNSA/NFO activity files in Las Vegas, Nevada, and can be obtained through written request to the NNSA/NFO Soils Activity Lead. This document is available in the DOE public reading facilities located in Las Vegas and Carson City, Nevada, or by contacting the appropriate DOE Soils Activity Lead. 


\subsection{References}

AAS, see American Aerial Surveys, Inc.

ASTM, see ASTM International.

American Aerial Surveys, Inc. 1964. Aerial photograph U3CF PRE-TEST 2, showing the test area located north of 3-03 Road.

ASTM International. 1995 (reapproved 2010). Standard Guide for Risk-Based Corrective Action Applied at Petroleum Release Sites, ASTM E1739 - 95(2010)e1. West Conshohocken, PA.

BN, see Bechtel Nevada.

Bechtel Nevada. 1997. An Aerial Radiological Survey of the Nevada Test Site and Surrounding Nellis Air Force Range, Southern Nevada, DOE/NV/11718-022. Prepared for U.S. Department of Energy, Nevada Operations Office. Las Vegas, NV: Remote Sensing Laboratory.

Bechtel Nevada. 1999a. An Aerial Radiological Survey of the Nevada Test Site, DOE/NV/11718--324. Prepared for U.S. Department of Energy, Nevada Operations Office. Las Vegas, NV: Remote Sensing Laboratory.

Bechtel Nevada. 1999b. A Series of Low-Altitude Aerial Radiological Surveys of Selected Regions within the Areas 3, 5, 8, 9, 11, 18, and 25 at the Nevada Test Site, DOE/NV/11718--362. Prepared by D.P. Colton for the U.S. Department of Energy, Nevada Operations Office. Las Vegas, NV: Remote Sensing Laboratory.

Buchheit, Jr., R., and C. Marianno. 2005. "Update of Technology for Use with FIDLER Detectors.” In Radiation Protection Management, Vol. 22(4): pp. 19-22.

CFR, see Code of Federal Regulations.

Code of Federal Regulations. 2013a. Title 40 CFR, Parts 260 to 282, "Hazardous Waste Management System.” Washington, DC: U.S. Government Printing Office.

Code of Federal Regulations. 2013b. Title 40 CFR, Part 761, "Polychlorinated Biphenyls (PCBs) Manufacturing, Processing, Distribution in Commerce, and Use Prohibitions.” Washington, DC: U.S. Government Printing Office.

DOE/NV, see U.S. Department of Energy, Nevada Operations Office.

DRI, see Desert Research Institute. 
Desert Research Institute. 1988. CERCLA Preliminary Assessment of DOE's Nevada Operations Office Nuclear Weapons Testing Areas. April. Las Vegas, NV.

EPA, see U.S. Environmental Protection Agency.

ERDA, see Energy Research and Development Administration.

Energy Research and Development Administration. 1977. Final Environmental Impact Statement, Nevada Test Site, Nye County, Nevada, ERDA-1551. Washington, DC.

FFACO, see Federal Facility Agreement and Consent Order.

Federal Facility Agreement and Consent Order. 1996 (as amended March 2010). Agreed to by the State of Nevada; U.S. Department of Energy, Environmental Management; U.S. Department of Defense; and U.S. Department of Energy, Legacy Management. Appendix VI, which contains the Soils Sites Strategy, was last modified May 2011, Revision No. 4.

Fenelon, J.M., D.S. Sweetkind, and R.J. Laczniak. 2010. Groundwater Flow Systems at the Nevada Test Site, Nevada: A Synthesis of Potentiometric Contours, Hydrostratigraphy, and Geologic Structures, Professional Paper 1771. Reston, VA: U.S. Geological Survey.

Fritzche, A.E. 1981. An Aerial Radiological Survey of Areas 1, 2, 3, 4, 6, 7, 8, 9, 10, 12, 15, and 17, Yucca Flat, Nevada Test Site, EG-1183-1808. Prepared for the U.S. Department of Energy, Nevada Operations Office. Las vegas, NV: EG\&G Energy Measurements Group, Inc.

Frizzell, V.A., and J. Shulters. 1990. Geologic Map of the Nevada Test Site, Southern Nevada, Map I-2046. Denver, CO: U.S. Geological Survey.

GE, see General Electric Company-TEMPO.

General Electric Company-TEMPO. 1979. Compilation of Local Fallout Data from Test Detonations 1945-1962 Extracted from DASA 1251, Volume I, DNA 1251-1-EX. 1 May. Prepared for Defense Nuclear Agency. Santa Barbara, CA: DASIAC.

Gilbert, R.O., E.H. Essington, D.N. Brady, P.G. Doctor, and L.L Eberhardt. 1977. "Statistical Activities during 1976 and the Design and Initial Analysis of Nuclear Site Studies." In Transuranics in Desert Ecosystems, NVO-181. pp. 331-366. November. Las Vegas, NV: U.S. Department of Energy, Nevada Operations Office.

Gray, K.J., D.S. Shafer, K. Self, C. Martin, and R. McArthur. 2007. Radionuclide Inventory and Distribution Program Database, Rev. 2. April. Las Vegas, NV: Desert Research Institute, Water Resources Center. 
Hevesi, J.A., A.L. Flint, and L.E. Flint. 2003. Simulation of Net Infiltration and Potential Recharge Using a Distributed-Parameter Watershed Model of the Death Valley Region, Nevada and California, Water-Resources Investigations Report 03-4090. Sacramento, CA: U.S. Geological Survey.

Holmes \& Narver, see Holmes \& Narver, Inc.

Holmes \& Narver, Inc. 1958. Completion Report Operation Hardtack II, Phase II. Prepared for the U.S. Atomic Energy Commission.

Kwicklis, E.M., A.V. Wolfsberg, P.H. Stauffer, M.A. Walvoord, and M. Sulley. 2006. Numerical Evaluation of Liquid and Vapor Fluxes at the Nevada Test Site Area 3 Radioactive Waste Management Site Using Hydrologic Data and Natural Environmental Tracers, LA-UR-06-1212. Los Alamos, NM: Los Alamos National Laboratory.

Laczniak, R.J., J.C. Cole, D.A. Sawyer, and D.A. Trudeau. 1996. Summary of Hydrogeologic Controls on Ground-Water Flow at the Nevada Test Site, Nye County, Nevada, Water-Resources Investigations Report 96-4109. Carson City, NV: U.S. Geological Survey.

McArthur, R.D., and J.F. Kordas. 1983. Radionuclide Inventory and Distribution Program: The Galileo Area, DOE/NV/10162-14; Publication No. 45035. Las Vegas, NV: Desert Research Institute, Water Resources Center.

McArthur, R.D., and J.F. Kordas. 1985. Nevada Test Site Radionuclide Inventory and Distribution Program: Report \#2. Areas 2 and 4, DOE/NV/10162-20; Publication No. 45041. Las Vegas, NV: Desert Research Institute, Water Resources Center.

McArthur, R.D., and S.W. Mead. 1987. Nevada Test Site Radionuclide Inventory and Distribution Program: Report \#3. Areas 3, 7, 8, 9, and 10, DOE/NV/10384-15; Publication No. 45056. Las Vegas, NV: Desert Research Institute, Water Resources Center.

Moore, J., Science Applications International Corporation. 1999. Memorandum to M. Todd (SAIC) titled “Background Concentrations for NTS and TTR Soil Samples," 3 February. Las Vegas, NV: IT Corporation.

NAC, see Nevada Administrative Code.

NBMG, see Nevada Bureau of Mines and Geology.

NDEP, see Nevada Division of Environmental Protection.

N-I GIS, see Navarro-Intera Geographic Information Systems.

NNSA/NFO, see U.S. Department of Energy, National Nuclear Security Administration Nevada Field Office. 
NNSA/NSO, see U.S. Department of Energy, National Nuclear Security Administration Nevada Site Office.

NNSA/NV, see U.S. Department of Energy, National Nuclear Security Administration Nevada Operations Office.

Navarro-Intera Geographic Information Systems. 2013. ESRI ArcGIS Software.

Navarro-Intera Geographic Information Systems. 2014. ESRI ArcGIS Software.

Nevada Administrative Code. 2012a. NAC 445A.227, “Contamination of Soil: Order by Director for Corrective Action; Factors To Be Considered in Determining Whether Corrective Action

Required.” Carson City, NV. As accessed at http://www.leg.state.nv.us/nac on 9 September 2013.

Nevada Administrative Code. 2012b. NAC 445A.22705, "Contamination of Soil: Evaluation of Site by Owner or Operator; Review of Evaluation by Division.” Carson City, NV. As accessed at http://www.leg.state.nv.us/nac on 9 September 2013.

Nevada Bureau of Mines and Geology. 1998. Mineral and Energy Resource Assessment of the Nellis Air Force Range, Open-File Report 98-1. Reno, NV.

Nevada Division of Environmental Protection. 2006 (as amended August 2000). Class III Solid Waste Disposal Site for Hydrocarbon Burdened Soils, Area 6 of the NTS, Permit SW 13-097-02, Rev. 7. Carson City, NV.

REECo, see Reynolds Electrical \& Engineering Co., Inc.

RSL, see Remote Sensing Laboratory.

Remote Sensing Laboratory. 2003. Aerial Photograph “NNSA-RSL_11189-46,” 4 December. Las Vegas, NV.

Reynolds Electrical \& Engineering Co., Inc. 1959. Area 3 Decontamination Report, November 1959. Mercury, NV.

Riedhauser, S.R. 1999. A Radiological Characterization of the Kiwi-I Vehicle, DOE/NV/11718--298. Las Vegas, NV: Bechtel Nevada, Remote Sensing Laboratory.

SNJV, see Stoller-Navarro Joint Venture.

Schoengold, C.R., M.E. DeMarre, and E.M. Kirkwood. 1996. Radiological Effluents Released from U.S. Continental Tests 1961 through 1992, DOE/NV-317 (Rev. 1), UC-702. August. Prepared for the U.S. Department of Energy, Nevada Operations Office. Las Vegas, NV: Bechtel Nevada. 
Soule, D.A. 2006. Climatology of the Nevada Test Site, SORD Technical Memorandum 2006-03. Silver Spring, MD: National Oceanographic and Atmospheric Administration, Air Resources Laboratory.

Stampahar, J., Remote Sensing Laboratory. 2012. Personal communication to M. Knop (N-I) regarding NNSS 2012 Radiological Flyover of Area 3, 5 June. Las Vegas, NV.

Stoller-Navarro Joint Venture. 2006. Phase I Hydrologic Data for the Groundwater Flow and Contaminant Transport Model of Corrective Action Unit 97: Yucca Flat/Climax Mine, Nevada Test Site, Nye County, Nevada, Rev. 0, S-N/99205--077. Las Vegas, NV.

TSA Systems, see TSA Systems, Ltd.

Tamura, T. 1977. "Plutonium Distribution in a Desert Pavement-Desert Mound Soil System in Area 11.” In Environmental Plutonium on the Nevada Test Site and Environs, NVO-171. June. Las Vegas, NV: Energy Research and Development Administration, Nevada Applied Ecology Group.

TSA Systems, Ltd. 2005. PRM-470CGN Operations Manual, Doc. \#5200, Rev. A. Longmont, CO.

USGS, see U.S. Geological Survey.

U.S. Department of Energy, National Nuclear Security Administration Nevada Field Office. 2013. Soils Risk-Based Corrective Action Evaluation Process, DOE/NV--1475-ROTC 2. Las Vegas, NV.

U.S. Department of Energy, National Nuclear Security Administration Nevada Operations Office. 2002. Nevada Test Site Orthophoto Site Atlas, DOE/NV/11718--604. Aerial photos acquired Summer 1998. Prepared by Bechtel Nevada. Las Vegas, NV.

U.S. Department of Energy, National Nuclear Security Administration Nevada Site Office. 2012. Soils Activity Quality Assurance Plan, Rev. 0, DOE/NV--1478. Las Vegas, NV.

U.S. Department of Energy, National Nuclear Security Administration Nevada Site Office. 2013. Nevada National Security Site Waste Acceptance Criteria, DOE/NV-325-Rev. 10. Las Vegas, NV.

U.S. Department of Energy, Nevada Operations Office. 1992. Remedial Investigation and Feasibility Study for the Plutonium Contaminated Soils at Nevada Test Site, Nellis Air Force Range and Tonopah Test Range. April. Las Vegas, NV.

U.S. Department of Energy, Nevada Operations Office. 1996. Final Environmental Impact Statement for the Nevada Test Site and Off-Site Locations in the State of Nevada, DOE/EIS-0243. August. Las Vegas, NV: 
U.S. Department of Energy, Nevada Operations Office. 2000a. Nevada Test Site Contaminated Land Areas Report, Volume I, DOE/NV/11718-481-VOL 1. Las Vegas, NV.

U.S. Department of Energy, Nevada Operations Office. 2000b. United States Nuclear Tests, July 1945 through September 1992, DOE/NV--209-Rev 15. Las Vegas, NV.

U.S. Environmental Protection Agency. 2013. Pacific Southwest, Region 9: Regional Screening Levels (Formerly PRGs), Screening Levels for Chemical Contaminants. As accessed at http://www.epa.gov/region9/superfund/prg on 9 September. Prepared by EPA Office of Superfund and Oak Ridge National Laboratory.

U.S. Geological Survey. 2013. “Groundwater Levels for Nevada.” As accessed at http://nwis.waterdata.usgs.gov/nv/nwis/gwlevels on 9 September.

Yu, C., A.J. Zielen, J.-J. Cheng, D.J. LePoire, E. Gnanapragasam, S. Kamboj, J. Arnish, A. Wallo III, W.A. Williams, and H. Peterson. 2001. User's Manual for RESRAD Version 6, ANL/EAD-4. Argonne, IL: Argonne National Laboratory, Environmental Assessment Division. (Version 6.5 released in October 2009.)

Yucel, V. National Security Technologies, LLC. 2009. Personal communication to R.L. Kidman (N-I) regarding PET data, 30 April. Las Vegas, NV. 


\section{Appendix A}

\section{Data Quality Objectives}




\section{A.1.0 Introduction}

The DQO process described in this appendix is a seven-step strategic systematic planning method used to plan data collection activities and define performance criteria for the CAU 568, Area 3 Plutonium Dispersion Sites, field investigation. DQOs are designed to ensure that the data collected will provide sufficient and reliable information to identify, evaluate, and technically defend recommended corrective actions (i.e., no further action, closure in place, or clean closure). Existing information about the nature and extent of contamination at the CASs in CAU 568 is insufficient to evaluate and select preferred corrective actions; therefore, a CAI will be conducted.

The CAU 568 CAI will be based on the DQOs presented in this appendix as developed by NDEP and NNSA/NFO representatives. The seven steps of the DQO process presented in Sections A.2.0 through A.8.0 were developed in accordance with Guidance on Systematic Planning Using the Data Quality Objectives Process (EPA, 2006).

In general, the procedures used in the DQO process provide the following:

- A method to establish performance or acceptance criteria, which serve as the basis for designing a plan for collecting data of sufficient quality and quantity to support the goals of a study.

- Criteria that will be used to establish the final data collection design, such as

- the nature of the problem that has initiated the study and a conceptual model of the environmental hazard to be investigated;

- the decisions or estimates that need to be made, and the order of priority for resolving them;

- $\quad$ the type of data needed; and

- an analytic approach or decision rule that defines the logic for how the data will be used to draw conclusions from the study findings.

- Acceptable quantitative criteria on the quality and quantity of the data to be collected, relative to the ultimate use of the data. 
- A data collection design that will generate data meeting the quantitative and qualitative criteria specified. A data collection design specifies the type, number, location, and physical quantity of samples and data, as well as the QA and QC activities that will ensure that sampling design and measurement errors are managed sufficiently to meet the performance or acceptance criteria specified in the DQOs. 


\section{A.2.0 Step 1 - State the Problem}

Step 1 of the DQO process defines the problem that requires study, identifies the planning team, and develops a conceptual model of the environmental hazard to be investigated.

The problem statement for CAU 568 is as follows: "Existing information on the nature and extent of potential contamination is insufficient to evaluate and recommend CAAs for the CASs in CAU 568.”

\section{A.2.1 Planning Team Members}

The DQO planning team consists of representatives from NDEP and NNSA/NFO. The DQO planning team met on August 27, 2013, for the DQO meeting.

\section{A.2.2 Conceptual Site Model}

The CSM is used to organize and communicate information about site characteristics. It reflects the best interpretation of available information at a point in time. The CSM is a primary vehicle for communicating assumptions about release mechanisms, potential migration pathways, or specific constraints. It provides a summary of how and where contaminants are expected to move and what impacts such movement may have. It is the basis for assessing how contaminants could reach receptors both in the present and future. The CSM describes the most probable scenario for current conditions at each site and defines the assumptions that are the basis for identifying appropriate sampling strategy and data collection methods. An accurate CSM is important as it serves as the basis for all subsequent inputs and decisions throughout the DQO process.

The CSM was developed for CAU 568 using information from the physical setting, potential contaminant sources, release information, historical background information, knowledge from similar sites, and physical and chemical properties of the potentially affected soil and COPCs.

The CSM consists of the following:

- Potential contaminant releases, including soil subsequently affected

- Release mechanisms (the conditions associated with the release) 
- Potential contaminant source characteristics, including contaminants suspected to be present and contaminant-specific properties

- Site characteristics, including physical, topographical, and meteorological information

- Migration pathways and transport mechanisms that describe the potential for migration and where the contamination may be transported

- The locations of points of exposure where individuals or populations may come in contact with a COC associated with a release

- Routes of exposure where contaminants may enter the receptor

If additional elements are identified during the CAI that are outside the scope of the CSM, the situation will be reviewed and a recommendation will be made as to how to proceed. In such cases, NDEP will be notified and given the opportunity to comment on, or concur with, the recommendation.

The applicability of the CSM to each release is summarized in Table A.2-1 and discussed below. Table A.2-1 provides information on CSM elements that will be used throughout the remaining steps of the DQO process. Figure A.2-1 depicts a representation of the conceptual pathways to receptors from CAU 568 sources. Figure A.2-2 depicts a graphical representation of the CSM.

\section{A.2.2.1 Release Sources}

The following identifies the release sources (DOE/NV, 2000) specific to CAU 568:

- Chavez, a tower safety experiment, was conducted on October 27, 1958, as part of Operation Hardtack II. The test was detonated atop a tower at a height of $52.5 \mathrm{ft}$. The yield from the test was 0.6 tons.

- Otero, a shaft safety experiment, was conducted on September 12, 1958, as part of Operation Hardtack II. The test was detonated at a depth of $480 \mathrm{ft}$ bgs and had a yield of 38 tons.

- $\quad$ Platypus, a weapons-related shaft test, was conducted on February 24, 1962, as part of Operation Nougat. The test was detonated at a depth of $190 \mathrm{ft}$ bgs and had a low yield.

- San Juan, a shaft safety experiment, was conducted on October 20, 1958, as part of Operation Hardtack II. The test was detonated at a depth of $234 \mathrm{ft}$ bgs and had a zero yield. 
Table A.2-1

CSM Description of Elements for Each Release in CAU 568

(Page 1 of 3 )

\begin{tabular}{|c|c|c|c|c|c|c|c|}
\hline Release Name & $\begin{array}{l}\text { Weapons-Related } \\
\text { Test Releases: } \\
\text { Shrew, } \\
\text { Wolverine, } \\
\text { Platypus, } \\
\text { Cognac, } \\
\text { Chinchilla II, } \\
\text { Stoat, Chinchilla, } \\
\text { Armadillo, } \\
\text { Haymaker, } \\
\text { Solendon, Mink, } \\
\text { Boomer, Funnel, } \\
\text { Tuna, and } \\
\text { Tendrac }\end{array}$ & $\begin{array}{c}\text { Safety } \\
\text { Experiment } \\
\text { Releases: Otero, } \\
\text { San Juan, } \\
\text { Chavez, } \\
\text { Pascal-A, } \\
\text { Colfax, } \\
\text { Pascal-B, Luna, } \\
\text { Bernalillo, } \\
\text { Pascal-C, } \\
\text { Valencia, and } \\
\text { Chipmunk }\end{array}$ & Drainages & Windrows & $\begin{array}{l}\text { Lead } \\
\text { Batteries, } \\
\text { Lead Brick, } \\
\text { Lead Plates, } \\
\text { Lead Sheet }\end{array}$ & Transformer & $\begin{array}{c}\text { Soil/Debris } \\
\text { Piles }\end{array}$ \\
\hline Site Status & \multicolumn{7}{|c|}{ Sites are inactive and/or abandoned } \\
\hline Exposure Scenario & \multicolumn{7}{|c|}{ Occasional Use } \\
\hline $\begin{array}{c}\text { Release } \\
\text { Description }\end{array}$ & $\begin{array}{l}\text { Atmospheric } \\
\text { deposition of } \\
\text { radionuclides from } \\
\text { nuclear testing }\end{array}$ & $\begin{array}{l}\text { Atmospheric } \\
\text { deposition of } \\
\text { radionuclides from } \\
\text { nuclear testing }\end{array}$ & $\begin{array}{l}\text { Potential } \\
\text { translocation of } \\
\text { radionuclides } \\
\text { originally } \\
\text { distributed on } \\
\text { the soil surface } \\
\text { into the } \\
\text { stormwater } \\
\text { collection } \\
\text { system }\end{array}$ & $\begin{array}{l}\text { Blading of } \\
\text { contaminated } \\
\text { soil into } \\
\text { windrows; } \\
\text { application of } \\
\text { oils to the } \\
\text { surface of } \\
\text { the windrows }\end{array}$ & $\begin{array}{l}\text { Potential } \\
\text { release of } \\
\text { oxidized lead } \\
\text { into the soil } \\
\text { beneath and } \\
\text { around the } \\
\text { lead item }\end{array}$ & $\begin{array}{l}\text { Potential } \\
\text { release of oil } \\
\text { from the } \\
\text { transformer onto } \\
\text { the soil beneath } \\
\text { and around } \\
\text { the transformer }\end{array}$ & $\begin{array}{l}\text { Potential } \\
\text { release of } \\
\text { chemical or } \\
\text { radiological } \\
\text { contaminants } \\
\text { from items } \\
\text { within the piles } \\
\text { from unknown } \\
\text { original location }\end{array}$ \\
\hline
\end{tabular}


Table A.2-1

CSM Description of Elements for Each Release in CAU 568

(Page 2 of 3 )

\begin{tabular}{|c|c|c|c|c|c|c|c|}
\hline Release Name & $\begin{array}{l}\text { Weapons-Related } \\
\text { Test Releases: } \\
\text { Shrew, } \\
\text { Wolverine, } \\
\text { Platypus, } \\
\text { Cognac, } \\
\text { Chinchilla II, } \\
\text { Stoat, Chinchilla, } \\
\text { Armadillo, } \\
\text { Haymaker, } \\
\text { Solendon, Mink, } \\
\text { Boomer, Funnel, } \\
\text { Tuna, and } \\
\text { Tendrac }\end{array}$ & $\begin{array}{c}\text { Safety } \\
\text { Experiment } \\
\text { Releases: Otero, } \\
\text { San Juan, } \\
\text { Chavez, } \\
\text { Pascal-A, } \\
\text { Colfax, } \\
\text { Pascal-B, Luna, } \\
\text { Bernalillo, } \\
\text { Pascal-C, } \\
\text { Valencia, and } \\
\text { Chipmunk }\end{array}$ & Drainages & Windrows & $\begin{array}{c} \\
\text { Lead } \\
\text { Batteries, } \\
\text { Lead Brick, } \\
\text { Lead Plates, } \\
\text { Lead Sheet }\end{array}$ & Transformer & $\begin{array}{c}\text { Soil/Debris } \\
\text { Piles }\end{array}$ \\
\hline $\begin{array}{l}\text { Location of } \\
\text { Contamination/ } \\
\text { Release Point }\end{array}$ & $\begin{array}{l}\text { Surface soil in radial } \\
\text { pattern surrounding } \\
\text { GZs or release } \\
\text { points; may be } \\
\text { present under } \\
\text { cleaner soil within } \\
\text { the bottom of craters }\end{array}$ & $\begin{array}{l}\text { Surface soil in } \\
\text { radial pattern } \\
\text { surrounding GZs or } \\
\text { release points; may } \\
\text { be present under } \\
\text { cleaner soil within } \\
\text { the bottom } \\
\text { of craters; } \\
\text { subsurface soil } \\
\text { within safety } \\
\text { experiments that } \\
\text { vented to } \\
\text { the surface }\end{array}$ & $\begin{array}{l}\text { Surface and } \\
\text { shallow } \\
\text { subsurface soil }\end{array}$ & $\begin{array}{c}\text { Surface of } \\
\text { windrowed soil }\end{array}$ & $\begin{array}{l}\text { Surface and } \\
\text { shallow } \\
\text { subsurface soil } \\
\text { at location of } \\
\text { lead item }\end{array}$ & $\begin{array}{l}\text { Surface and } \\
\text { shallow } \\
\text { subsurface soil } \\
\text { at location } \\
\text { of transformer }\end{array}$ & $\begin{array}{l}\text { Surface and } \\
\text { shallow } \\
\text { subsurface soil }\end{array}$ \\
\hline Amount Released & \multicolumn{7}{|c|}{ Unknown } \\
\hline Affected Media & \multicolumn{7}{|c|}{ Surface, shallow subsurface, and subsurface soil; drainage sediments } \\
\hline
\end{tabular}


Table A.2-1

CSM Description of Elements for Each Release in CAU 568

(Page 3 of 3 )

\begin{tabular}{|c|c|c|c|c|c|c|c|}
\hline Release Name & $\begin{array}{l}\text { Weapons-Related } \\
\text { Test Releases: } \\
\text { Shrew, } \\
\text { Wolverine, } \\
\text { Platypus, } \\
\text { Cognac, } \\
\text { Chinchilla II, } \\
\text { Stoat, Chinchilla, } \\
\text { Armadillo, } \\
\text { Haymaker, } \\
\text { Solendon, Mink, } \\
\text { Boomer, Funnel, } \\
\text { Tuna, and } \\
\text { Tendrac }\end{array}$ & $\begin{array}{c}\text { Safety } \\
\text { Experiment } \\
\text { Releases: Otero, } \\
\text { San Juan, } \\
\text { Chavez, } \\
\text { Pascal-A, } \\
\text { Colfax, } \\
\text { Pascal-B, Luna, } \\
\text { Bernalillo, } \\
\text { Pascal-C, } \\
\text { Valencia, and } \\
\text { Chipmunk }\end{array}$ & Drainages & Windrows & $\begin{array}{l}\text { Lead } \\
\text { Batteries, } \\
\text { Lead Brick, } \\
\text { Lead Plates, } \\
\text { Lead Sheet }\end{array}$ & Transformer & $\begin{array}{l}\text { Soil/Debris } \\
\text { Piles }\end{array}$ \\
\hline $\begin{array}{l}\text { Potential } \\
\text { Contaminants }\end{array}$ & \multicolumn{7}{|c|}{ See Table A.2-2. } \\
\hline $\begin{array}{l}\text { Transport } \\
\text { Mechanisms }\end{array}$ & \multicolumn{7}{|c|}{$\begin{array}{l}\text { Percolation of precipitation through subsurface soil serves as the major driving force for migration of contaminants. Surface water runoff } \\
\text { may provide for the transportation of some contaminants within or outside the footprints of the releases. }\end{array}$} \\
\hline Migration Pathways & \multicolumn{7}{|c|}{$\begin{array}{l}\text { For subsurface migration, vertical transport expected to dominate over lateral transport due to small surface drainage features. For } \\
\text { surface migration, lateral transport expected to dominate over vertical due to large PET demands and low precipitation amounts. The } \\
\text { large depth to the uppermost aquifer precludes groundwater as a significant pathway. }\end{array}$} \\
\hline $\begin{array}{l}\text { Lateral and Vertical } \\
\text { Extent of } \\
\text { Contamination }\end{array}$ & \multicolumn{7}{|c|}{$\begin{array}{l}\text { Contamination, if present, is expected to be contiguous to the release points. Concentrations are expected to decrease with distance } \\
\text { and depth from the source. Lateral and vertical extent of contamination exceeding FALs is assumed to be within the spatial boundaries. }\end{array}$} \\
\hline $\begin{array}{l}\text { Exposure } \\
\text { Pathways }\end{array}$ & \multicolumn{7}{|c|}{$\begin{array}{l}\text { The potential for contamination exposure is limited to industrial and construction workers, and military personnel conducting training. } \\
\text { These human receptors may be exposed to COPCs through oral ingestion or inhalation of, or dermal contact (absorption) with soil } \\
\text { and/or debris due to inadvertent disturbance of these materials, or irradiation by radioactive materials. }\end{array}$} \\
\hline
\end{tabular}




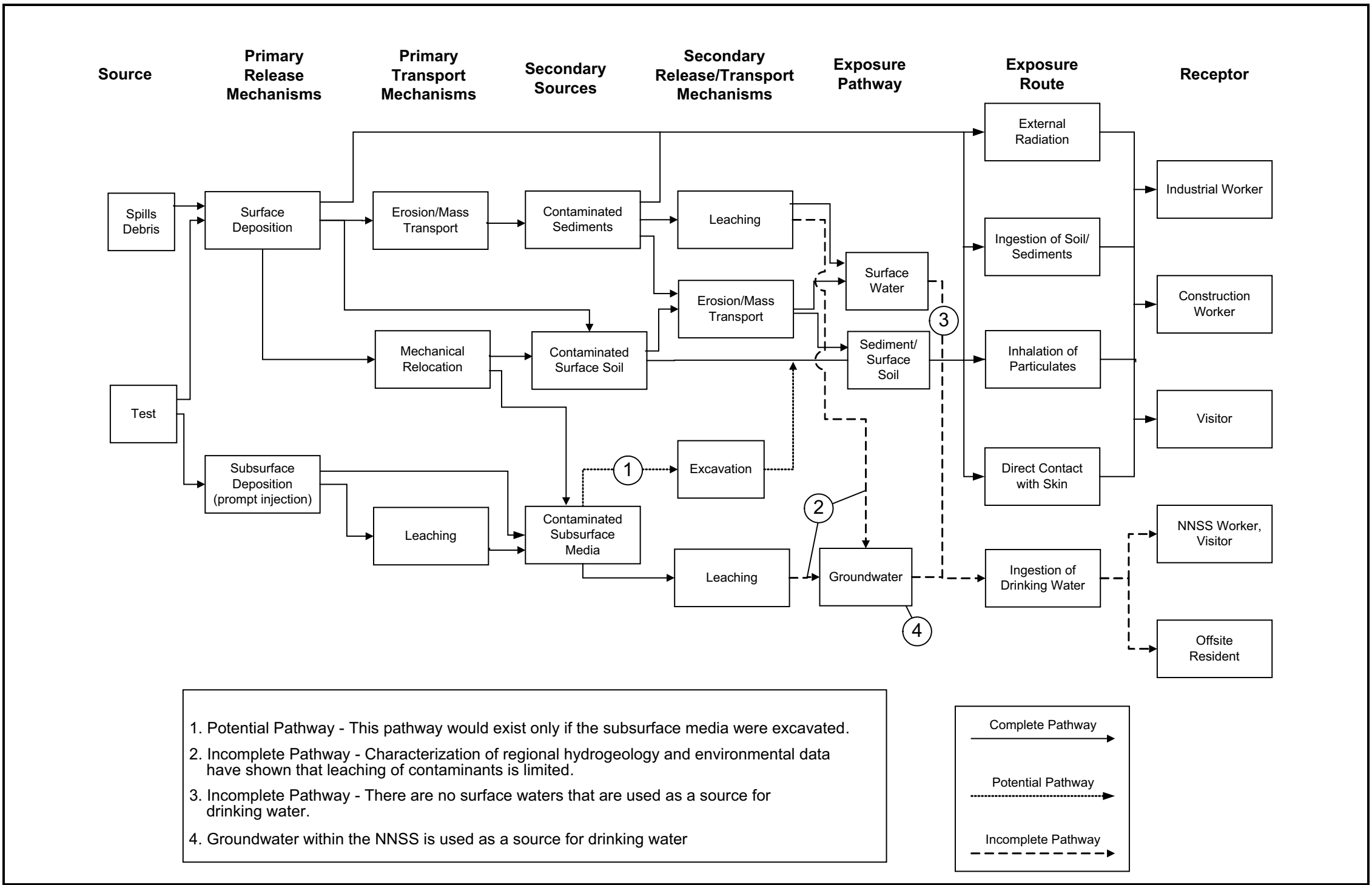

Figure A.2-1

CAU 568 CSM Pathways to Receptors

\section{UNCONTROLLED When Printed}




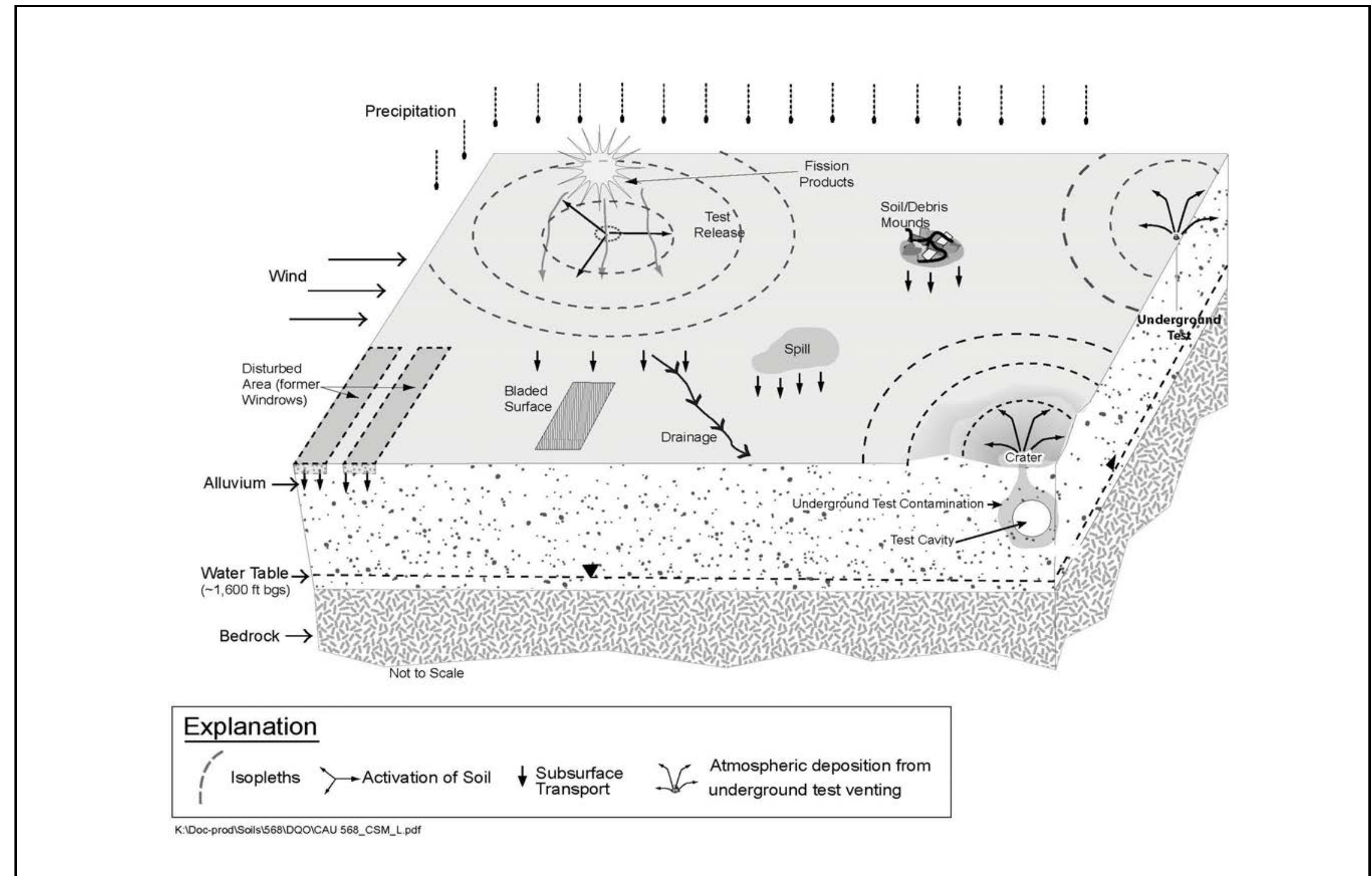

Figure A.2-2

CSM for CAU 568 
- Shrew, a weapons-related shaft test, was conducted on September 16, 1961, as part of Operation Nougat. The test was detonated at a depth of $322 \mathrm{ft}$ bgs and had a low yield.

- Wolverine, a weapons-related shaft test, was conducted on October 12, 1962, as part of Operation Storax. The test was detonated at a depth of $240 \mathrm{ft}$ bgs and had a low yield.

- In addition to the aforementioned test releases, 20 tests in the vicinity of CAU 568 were identified as having released radioactivity to the surface. These 20 test releases will be investigated within the scope of CAU 568. These 20 sites are defined as the release of contaminants associated with the Cognac, Chinchilla II, Stoat, Chinchilla, Armadillo, Haymaker, Solendon, Mink, Boomer, Funnel, and Tuna weapons-related shaft tests; the Pascal-A, Colfax, Pascal-B, Luna, Bernalillo, Pascal-C, Valencia, and Chipmunk shaft safety experiments, and the Tendrac joint US/UK shaft test. These tests were conducted between 1957 and 1968 with yields ranging from slight to $67 \mathrm{kt}$.

- Migration of contaminants from the test releases may have occurred at the site. During recent precipitation events, a minor drainage was identified flowing from the CA on the north side of 3-03 Road into a nearby crater. Additional visual surveys will be conducted during the CAI to identify any other drainages at CAU 568.

- Windrows, which may have had oil sprayed on them, were created in 1959. The windrows were removed from the site. Therefore, the release from these windrows may have been translocated anywhere in the windrow area.

- Other releases are present at CAU 568. Lead batteries, lead plates, a lead brick, and a lead sheet were identified. A transformer is present within the CA at San Juan and Otero. Additionally, soil and debris piles are present that may have released contaminants to the soil. These soil piles have an unknown origin and may not have originated from releases in the area (may have originated from other releases on the NNSS). There is the potential to find additional spills or debris that could provide a source for the release of contamination to the surface soils.

The most likely locations of the contamination and releases to the environment are the soils directly below or adjacent to the CSM's surface and subsurface components (i.e., soils impacted by fallout). Contamination may have been moved through migration in drainages or during windrow formation.

DQOs for CAU 568 defined similarities in CSM properties of several releases that would allow a common investigative approach (e.g., surface deposition of relatively immobile contaminants, presence of subsidence craters or potential crater areas, or similarities in release sources such as weapons tests or safety experiments). Based on these similarities, the study groups defined in Section 1.1.2 were established to simplify the planning and investigation of various releases. 


\section{A.2.2.2 Potential Contaminants}

The release-specific COPCs are defined as the contaminants reasonably expected at the site that could contribute to a dose or risk exceeding FALs. Based on the nature of the releases identified in Section 2.4 and previous investigation results presented in Section 2.5, the contaminants listed in Table A.2-2 could reasonably be suspected to be present at CAU 568. These COPCs were identified during the planning process through the review of site history, process knowledge, personal interviews, past investigation efforts (where available), and inferred activities associated with the releases (including those that may be discovered during the investigation).

Additional COPCs may be discovered during the investigation. Specific COPCs (and the analyses requested) will be determined for newly discovered releases based on the nature of the release (e.g., hydrocarbon stain, lead bricks).

Although not suspected to be present, analysis for additional COPCs will be performed where appropriate to evaluate the possibility of their presence due to an incomplete history of site testing operations. The site-specific possible but not suspected COPCs for CAU 568 are as follows:

- Cobalt (Co)-60

- Strontium (Sr)-90

- Technetium (Tc)-99

- $\quad$ Neptunium (Np)-237

- Pu-241

- Curium (Cm)-243

- Cm-244

- Am-243

- Silver (Ag)-108m

- Aluminum (Al)-26

- Niobium (Nb)-94

- Thorium (Th)-232

- U-233

Cobalt is included on this list because it is an activation product in soil. Strontium and technetium are included in this list due to their historical presence as fission product radionuclides. Radionuclides such as Np-237, Pu-241, Cm-243, and Cm-244 are included as possible radiological COPCs based on their reported historical use as tracers and/or surrogates. The plutonium ratios will be used to determine whether analysis for Cm-244 is needed. One sample (with the highest alpha FSR) will be analyzed for Pu-241 from each plutonium dispersal site. For Sr-90 analysis, one sample will be 
analyzed for Sr-90 from the expected location of the highest Cs-137 result. Additional sampling may be conducted based upon the 10 percent dose rule.

The COPCs applicable to Decision I environmental samples for each of the CAU 568 releases are listed in Table A.2-2. Table A.2-3 lists the analytical methods required for these COPCs, while Table A.2-4 lists the analytes that are reported by the analytical laboratory for each of the analytical methods.

\section{A.2.2.3 Contaminant Characteristics}

Contaminant characteristics include, but are not limited to, solubility, density, and adsorption potential. In general, contaminants with low solubility, high affinity for soil, and high density can be expected to be found relatively close to release points. Contaminants with small particle size, high solubility, low density, and/or low affinity for soil are found farther from release points or in low areas where evaporation of ponding will concentrate dissolved contaminants. Radionuclides with a low melting point (e.g., iodine) traveled significant distances before condensing and falling out of the plume, while those with higher melting points (e.g., cesium) condensed earlier and were deposited closer to respective GZs. Generally, nuclear fuel radionuclides that did not fission (e.g., U-235) have a very high melting point and are generally found very near GZ.

Residual radionuclide contaminants from nuclear weapons testing (after decay of the relatively short-lived radionuclides) are moderately to highly adsorbed on soils such as those present at CAU 568. An example of the inherent vertical migration potential of these contaminants through alluvium soils is presented in Table A.2-5. This table presents estimated ranges of contaminant sorption coefficients $\left(\mathrm{K}_{\mathrm{d}}\right)$ for major radionuclide contaminants within a Yucca Flat alluvium matrix (SNJV, 2007). From these $\mathrm{K}_{\mathrm{d}}$ values, equivalent retardation factors were calculated based on an average bulk density of 1.5 grams per cubic centimeter (Hevesi et al., 2003) and a conservative estimate of the average volumetric water content of 0.18 (based on van Genuchten model parameters in van Genuchten, 1980).

Based on these properties and a maximum estimated recharge rate of $5 \mathrm{~mm} / \mathrm{yr}$ (Hevesi et al., 2003), the major radionuclide contaminants at CAU 568 are estimated to migrate less than $2 \mathrm{~m}$ in 1,000 years except for uranium, which could migrate up to $12.5 \mathrm{~m}$ in 1,000 years. 
Table A.2-2

\section{Contaminants of Potential Concern ${ }^{\mathrm{a}}$}

(Page 1 of 2)

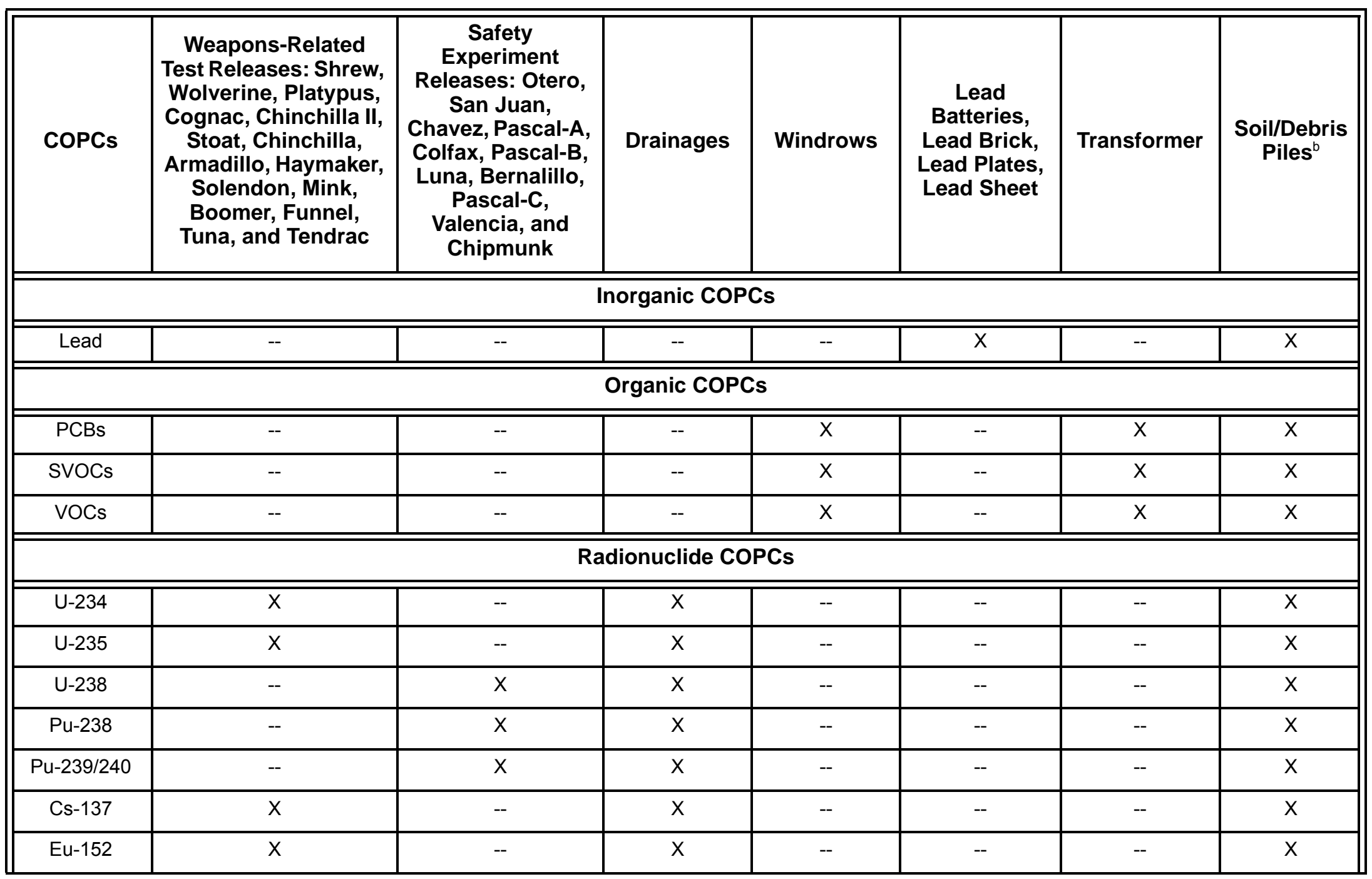


Table A.2-2

\section{Contaminants of Potential Concern ${ }^{\mathrm{a}}$}

(Page 2 of 2 )

\begin{tabular}{|c|c|c|c|c|c|c|c|}
\hline cOPCs & $\begin{array}{l}\text { Weapons-Related } \\
\text { Test Releases: Shrew, } \\
\text { Wolverine, Platypus, } \\
\text { Cognac, Chinchilla II, } \\
\text { Stoat, Chinchilla, } \\
\text { Armadillo, Haymaker, } \\
\text { Solendon, Mink, } \\
\text { Boomer, Funnel, } \\
\text { Tuna, and Tendrac }\end{array}$ & $\begin{array}{c}\text { Safety } \\
\text { Experiment } \\
\text { Releases: Otero, } \\
\text { San Juan, } \\
\text { Chavez, Pascal-A, } \\
\text { Colfax, Pascal-B, } \\
\text { Luna, Bernalillo, } \\
\text { Pascal-C, } \\
\text { Valencia, and } \\
\text { Chipmunk }\end{array}$ & Drainages & Windrows & $\begin{array}{c}\text { Lead } \\
\text { Batteries, } \\
\text { Lead Brick, } \\
\text { Lead Plates, } \\
\text { Lead Sheet }\end{array}$ & Transformer & $\begin{array}{c}\text { Soil/Debris } \\
\text { Piles }^{b}\end{array}$ \\
\hline Eu-154 & $x$ & -- & $x$ & -- & -- & -- & $x$ \\
\hline Eu-155 & $x$ & -- & $x$ & -- & -- & -- & $x$ \\
\hline Am-241 & -- & $x$ & $x$ & -- & -- & -- & $x$ \\
\hline
\end{tabular}

${ }^{a}$ The COPCs are the constituents that, based on process knowledge and historical documentation, are likely to be present.

${ }^{b} \mathrm{COPCs}$ for this study group depend on the nature of release.

$\mathrm{X}=\mathrm{COPC}$ associated with this study group

-- $=$ COPC not associated with this study group 
Table A.2-3

Analyses Required by Group

\begin{tabular}{|c|c|c|c|c|c|c|c|}
\hline Analyses & $\begin{array}{c}\text { Weapons-Related } \\
\text { Test Releases: } \\
\text { Shrew, Wolverine, } \\
\text { Platypus, Cognac, } \\
\text { Chinchilla II, Stoat, } \\
\text { Chinchilla, } \\
\text { Armadillo, } \\
\text { Haymaker, } \\
\text { Solendon, Mink, } \\
\text { Boomer, Funnel, } \\
\text { Tuna, and Tendrac }\end{array}$ & $\begin{array}{c}\text { Safety } \\
\text { Experiment } \\
\text { Releases: Otero, } \\
\text { San Juan, } \\
\text { Chavez, } \\
\text { Pascal-A, Colfax, } \\
\text { Pascal-B, Luna, } \\
\text { Bernalillo, } \\
\text { Pascal-C, } \\
\text { Valencia, and } \\
\text { Chipmunk }\end{array}$ & Drainages & Windrows & $\begin{array}{c}\text { Lead } \\
\text { Batteries, } \\
\text { Lead Brick, } \\
\text { Lead Plates, } \\
\text { Lead Sheet }\end{array}$ & Transformer & $\begin{array}{l}\text { Soil/Debris } \\
\text { Piles }^{b}\end{array}$ \\
\hline \multicolumn{8}{|c|}{ Inorganic COPCs } \\
\hline RCRA Metals & -- & -- & -- & -- & $\mathrm{X}$ & -- & $\mathrm{X}$ \\
\hline \multicolumn{8}{|c|}{ Organic COPCs } \\
\hline PCBs & -- & -- & -- & $\mathrm{X}$ & -- & $\mathrm{X}$ & $\mathrm{X}$ \\
\hline VOCs & -- & -- & -- & $x$ & -- & $x$ & $x$ \\
\hline SVOCs & -- & -- & -- & $x$ & -- & $x$ & $x$ \\
\hline \multicolumn{8}{|c|}{ Radionuclide COPCs } \\
\hline Gamma Spectroscopy & $\mathrm{X}$ & $\mathrm{X}$ & $\mathrm{X}$ & -- & -- & -- & $\mathrm{X}$ \\
\hline Isotopic U & $x$ & $x$ & $X$ & -- & -- & -- & $X$ \\
\hline Isotopic $\mathrm{Pu}$ & -- & $\mathrm{X}$ & $x$ & -- & -- & -- & $x$ \\
\hline Isotopic Am & -- & $X$ & $X$ & -- & -- & -- & $X$ \\
\hline
\end{tabular}

${ }^{a}$ The analytical method has been determined based on the site-specific COPCs. Analytical methods numbers are shown in Table A.2-4.

${ }^{\mathrm{b}}$ Analyses will be determined based on the nature of release.

X = Required analytical method as described in Soils QAP (NNSA/NSO, 2012)

$--=$ Not required 
Table A.2-4

\section{Analytes Reported Per Method}

\begin{tabular}{|c|c|c|c|c|c|c|c|}
\hline \multicolumn{5}{|c|}{ Organic COPCs } & \multirow{2}{*}{\begin{tabular}{|c|}
$\begin{array}{c}\text { Inorganic } \\
\text { COPCs }\end{array}$ \\
Method $6010^{a}$
\end{tabular}} & \multicolumn{2}{|c|}{$\begin{array}{l}\text { Radionuclide } \\
\text { COPCs }\end{array}$} \\
\hline \multicolumn{2}{|c|}{ Method $8260^{a}$} & \multicolumn{2}{|c|}{ Method $8270^{a}$} & Method $8082^{a}$ & & Method Ga-01" & MethodU-02 \\
\hline \multicolumn{2}{|c|}{$\begin{array}{ll}\text { VOCs } \\
\end{array}$} & \multicolumn{2}{|c|}{ SVOCs } & PCBs & RCRA Metals & Gamma Spec & Isotopic U \\
\hline $1,1,1,2$-Tetrachloroethane & Carbon tetrachloride & 1,4-Dioxane & Bis(2-ethylhexyl)phthalate & Aroclor 1016 & Arsenic & Ac-228 & $\mathrm{U}-234$ \\
\hline 1,1,1-Trichloroethane & Chlorobenzene & 2,3,4,6-Tetrachlorophenol & Butyl benzyl phthalate & Aroclor 1221 & Barium & Ag-108m & $\mathrm{U}-235$ \\
\hline 1,1,2,2-Tetrachloroethane & Chloroethane & 2,4,5-Trichlorophenol & Carbazole & Aroclor 1232 & Beryllium & Al-26 & $\mathrm{U}-238$ \\
\hline 1,1,2-Trichloroethane & Chloroform & 2,4,6-Trichlorophenol & Chrysene & Aroclor 1242 & Cadmium & Am-241 & \\
\hline 1,1-Dichloroethane & Chloromethane & 2,4-Dimethylphenol & Di-n-butyl phthalate & Aroclor 1248 & Chromium & $\mathrm{Cm}-243$ & Method Sr-02 \\
\hline 1,1-Dichloroethene & Chloroprene & 2,4-Dinitrotoluene & Di-n-octyl phthalate & Aroclor 1254 & Lead & Co-60 & Isotopic Sr \\
\hline 1,2,4-Trichlorobenzene & cis-1,2-Dichloroethene & 2-Chlorophenol & Dibenzo(a,h)anthracene & Aroclor 1260 & Selenium & Cs-137 & Sr-90 \\
\hline 1,2,4-Trimethylbenzene & Dibromochloromethane & 2-Methylnaphthalene & Dibenzofuran & Aroclor 1268 & Silver & Eu-152 & \\
\hline 1,2-Dibromo-3-chloropropane & Dichlorodifluoromethane & 2-Methylphenol & Dimethyl phthalate & & & Eu-154 & Method Pu-02 ${ }^{\circ}$ \\
\hline 1,2-Dichlorobenzene & Ethyl methacrylate & 2-Nitrophenol & Fluoranthene & & Method $7196^{a}$ & Eu-155 & Isotopic Pu \\
\hline 1,2-Dichloroethane & Ethylbenzene & 3-Methylphenol' (m-cresol) & Fluorene & & Chromium VI & $\mathrm{K}-40$ & Pu-238 \\
\hline 1,2-Dichloropropane & Isobutyl alcohol & 4-Methylphenol' (p-cresol) & Hexachlorobenzene & & & $\mathrm{Nb}-94$ & Pu-239/240 \\
\hline 1,3,5-Trimethylbenzene & Isopropylbenzene & 4-Chloroaniline & Hexachlorobutadiene & & & Pa-233 & \\
\hline 1,3-Dichlorobenzene & Methacrylonitrile & 4-Nitrophenol & Hexachloroethane & & & $\mathrm{Pb}-212$ & Method $\mathrm{Am}-01^{\mathrm{D}}$ \\
\hline 1,4-Dichlorobenzene & Methyl methacrylate & Acenaphthene & Indeno(1,2,3-cd)pyrene & & & $\mathrm{Pb}-214$ & Isotopic Am \\
\hline 2-Butanone & Methylene chloride & Acenaphthylene & n-Nitroso-di-n-propylamine & & & Th-229 & $\mathrm{Am}-241$ \\
\hline 2-Chlorotoluene & n-Butylbenzene & Aniline & Naphthalene & & & Th-234 & Am-243 \\
\hline 2-Hexanone & n-Propylbenzene & Anthracene & Nitrobenzene & & & TI-208 & \\
\hline 4-Isopropyltoluene & sec-Butylbenzene & Benzo(a)anthracene & Pentachlorophenol & & & U-235 & \\
\hline 4-Methyl-2-pentanone & Styrene & Benzo(a)pyrene & Phenanthrene & & & & \\
\hline Acetone & tert-Butylbenzene & Benzo(b)fluoranthene & Phenol & & & Lab-Speci & c Methods ${ }^{d}$ \\
\hline Acetonitrile & Tetrachloroethene & Benzo(g,h,i)perylene & Pyrene & & & $\mathrm{Pu}-241$ & \\
\hline Allyl chloride & Toluene & Benzo(k)fluoranthene & Pyridine & & & Tc-99 & \\
\hline Benzene & Total xylenes & Benzoic acid & Diethyl phthalate & & & & \\
\hline Bromodichloromethane & Trichloroethene & Benzyl alcohol & & & & & \\
\hline Bromoform & Trichlorofluoromethane & & & & & & \\
\hline Bromomethane & Vinyl acetate & & & & & & \\
\hline Carbon disulfide & Vinyl chloride & & & & & & \\
\hline
\end{tabular}

${ }^{\mathrm{a}}$ Test Methods for Evaluating Solid Waste, Physical/Chemical Methods (EPA, 2013b)

${ }^{\mathrm{b} T h e}$ Procedures Manual of the Environmental Measurements Laboratory, which includes HASL-300 Methods (DOE, 1997)

The most current EPA, DOE, or equivalent accepted analytical method may be used including; Laboratory Standard Operating Procedures approved by the contractor in accordance with industry standards and the contractor's SOW requirements.

HASL = Health and Safety Laboratory

$$
\begin{array}{ll}
\mathrm{Ac}=\text { Actinium } & \mathrm{Pb}=\text { Lead } \\
\mathrm{Al}=\text { Aluminum } & \mathrm{Tl}=\text { Thallium }
\end{array}
$$


Table A.2-5

\section{Vertical Migration Potential through the Vadose Zone of the Major Radionuclide Contaminants}

\begin{tabular}{|c|c|c|c|}
\hline $\begin{array}{c}\text { Contaminant } \\
\text { of Concern }\end{array}$ & $\begin{array}{c}\text { Range of } \mathbf{K}_{\mathbf{d}} \text { Values } \\
(\mathbf{m L} / \mathbf{g})\end{array}$ & $\begin{array}{c}\text { Equivalent } \\
\text { Retardation Factor }\end{array}$ & $\begin{array}{c}\text { Maximum Migration } \\
(\mathbf{m} / \mathbf{1}, \mathbf{0 0 0} \text { years) }\end{array}$ \\
\hline \hline Uranium & $0.36-1.7$ & $4-15$ & 12.5 \\
\hline Plutonium & $3.4-102$ & $29-842$ & 1.7 \\
\hline Europium & $832-3,311$ & $6,840-27,228$ & $>0.1$ \\
\hline Strontium & $66-575$ & $544-4,733$ & $>0.1$ \\
\hline Cesium & $2,692-16,218$ & $22,132-133,355$ & $>0.1$ \\
\hline Americium & $3,020-12,023$ & $24,833-98,858$ & $>0.1$ \\
\hline
\end{tabular}

$\mathrm{mL} / \mathrm{g}=$ Milliliters per gram

An example of the migration potential of radionuclides released from a nuclear detonation was demonstrated in a long-term radionuclide migration study of an underground nuclear test. A well installed into the groundwater $91 \mathrm{~m}$ away from the Cambric test GZ (and much closer to the nearest extent of the test cavity) was continuously pumped from 1975 to 1991 in order to draw radionuclides from the detonation cavity. The May 1965 Cambric test released a yield of 750 tons at a depth of $294 \mathrm{~m}$ below the land surface and $73 \mathrm{~m}$ below the water table (DOE/NV, 2000;

Hoffman and Daniels, 1984). No radionuclides associated with nuclear fission tests (including the major contributing radionuclides plutonium, uranium, cesium, europium, strontium, or cobalt) other than tritium and krypton (which are considered to be conservative tracers in groundwater, as they do not interact with the geologic media through which the water moves) were detected in the pumped groundwater during the 16 years of pumping (Bryant, 1992; Hoffman and Daniels, 1984). This test demonstrated the relative immobility of the fission radionuclides under conditions of very high mass flow (more than 1.5 billion gallons of water pumped) in a saturated matrix. Under unsaturated conditions (such as surface soil with atmospheric deposition from nuclear test releases), infiltrating water percolating through the vadose zone provides a small fraction of the migration potential (mass flow is less than 5 millimeters of recharge per year [Hevesi et al., 2003]). Therefore, it can be assumed that while the major fission radionuclides are relatively immobile in saturated conditions with an artificial gradient (i.e., under pumping conditions), they will be even less mobile under unsaturated conditions with limited net infiltration of precipitation. 
Based on this evidence, the major radionuclide potential contaminants (associated with fission) are classified as adsorbing radionuclides with low solubilities that are located within unsaturated media. Therefore, these contaminants are expected to be found relatively close to release points.

\section{A.2.2.4 Site Characteristics}

Site characteristics are defined by the interaction of physical, topographical, and meteorological attributes and properties including slope stability, precipitation frequency and amounts, precipitation runoff pathways, drainage channels and ephemeral drainages, and evapotranspiration potential. Meteorological data are presented in Section 2.1.

CAU 568 is located in Area 3 of the NNSS in Yucca Flat. The area is relatively flat, gently sloping to the southeast. The area is sparsely vegetated with native plants. The soil at CAU 568 is made up of sand to gravel-sized alluvium of various lithologies and includes areas of disturbed soil (from site grading and the formation of windrows, road construction, and underground testing). No perennial streamflow exists in this region. The few ephemeral streams identified in the area flow into existing craters.

\section{A.2.2.5 Migration Pathways and Transport Mechanisms}

Migration pathways include the lateral migration of potential contaminants across surface soils/sediments and vertical migration of potential contaminants through subsurface soils. Contaminants present in ephemeral washes are subject to much higher transport rates than contaminants present in other surface areas. These ephemeral washes are generally dry but are subject to infrequent stormwater flows. These stormwater flow events provide an intermittent mechanism for both vertical and lateral transport of contaminants. Contaminated sediments entrained by these stormwater events would be carried by the drainage channel flow to locations where the flowing water loses energy and the sediments drop out. These locations are visually identifiable as sedimentation areas.

Other migration pathways for contamination from the sites include wind-borne material and materials displaced from maintenance activities (e.g., moved during road maintenance). Contaminants may also be moved through mechanical disturbance due to maintenance or construction activities at the 
site. Specifically, this can include activities such as decontamination and demolition of facilities, investigation and resolution of CASs, and disassembly and removal of equipment and support structures.

Migration is influenced by the chemical characteristics of the contaminants (presented in Section A.2.2.3) and the physical characteristics of the vadose zone material (presented in Section A.2.2.4). In general, the contaminants that are reasonably expected to be present at CAU 568 (i.e., Pu-239/-240, Am-241, and Cs-137) have low solubilities and high affinity for soil. The physical characteristics of the vadose zone material generally include medium and high adsorbive capacities, low moisture contents (i.e., available water-holding capacity), and relatively long distances to groundwater (approximately 1,600 ft bgs [USGS, 2013]). Based on these physical and chemical factors, contamination is expected to be found relatively close to release points.

Infiltration and percolation of precipitation serve as a driving force for downward migration of contaminants. However, due to high PET (annual PET at the Area 3 RWMS has been estimated at 61.7 in. [Yucel, 2009]) and limited precipitation for this region (6.3 in./yr [Soule, 2006]), percolation of infiltrated precipitation at the NNSS does not provide a significant mechanism for vertical migration of contaminants to groundwater (DOE/NV, 1992).

Underground test craters have associated chimneys of disturbed geologic material that may provide a preferential pathway. Collection of stormwater into these craters also provides additional localized infiltration that will enhance contaminant migration rates.

Subsurface migration pathways at CAU 568 are expected to be predominately vertical, although spills or leaks at the ground surface may also have limited lateral migration before infiltration. The depth of infiltration (shape of the subsurface contaminant plume) will be dependent upon the type, volume, and duration of the discharge as well as the presence of relatively impermeable layers that could modify vertical or lateral transport pathways, both on the ground surface (e.g., concrete) and in the subsurface (e.g., caliche layers). 


\section{A.2.2.6 Exposure Scenarios}

Human receptors may be exposed to COPCs through oral ingestion or inhalation of, or dermal contact (absorption) with, soil or debris due to inadvertent disturbance of these materials, or external irradiation by radioactive materials. The land-use and exposure scenarios for the CASs in CAU 568 are listed in Table A.2-6. This is based on current and future land use at the NNSS (DOE/NV, 1996). Although CAU 568 is located in an area where structures from past activities exist, no facilities are present that would allow these to be used as an assigned work station for NNSS site personnel. There is still the possibility, however, that site workers could occupy these locations on an occasional and temporary basis, such as a military exercise. Therefore, the current site usage at the CASs in CAU 568 is conservatively represented by the Occasional Use Area exposure scenario.

Table A.2-6

Land-Use and Exposure Scenarios

\begin{tabular}{|c|l|l|}
\hline CAS & \multicolumn{1}{|c|}{ Record of Decision Land-Use Zone } & \multicolumn{1}{c|}{ Exposure Scenario } \\
\hline \hline \multirow{3}{*}{ All } & $\begin{array}{l}\text { Nuclear and High Explosives Test } \\
\text { This area is designated within the Nuclear Test } \\
\text { Zone for additional underground nuclear } \\
\text { weapons tests and outdoor high-explosive tests. } \\
\text { This zone includes compatible defense and } \\
\text { nondefense research, development, and } \\
\text { testing activities. }\end{array}$ & $\begin{array}{l}\text { Occasional Use Area } \\
\text { (up to 80 hours per year for 5 years). Site } \\
\text { structures are not present for shelter and comfort } \\
\text { of the worker. }\end{array}$ \\
\hline
\end{tabular}




\section{A.3.0 Step 2 - Identify the Goal of the Study}

Step 2 of the DQO process states how environmental data will be used in meeting objectives and solving the problem, identifies study questions or decision statement(s), and considers alternative outcomes or actions that can occur upon answering the question(s).

\section{A.3.1 Decision Statements}

The Decision I statement is "Is any COC associated with the release present in environmental media?” For judgmental sampling design, any analytical result for a COPC above the FAL will result in that COPC being designated as a COC. For the probabilistic (unbiased) sampling design, any COPC that has a 95 percent UCL of the average concentration above the FAL will result in that COPC being designated as a COC. A COC may also be defined as a contaminant that, in combination with other like contaminants, is determined to jointly pose an unacceptable risk based on a multiple contaminant analysis (NNSA/NFO, 2013). If a COC is detected, then Decision II must be resolved.

The Decision II statement is "If corrective action is required, is sufficient information available to evaluate potential CAAs?” Sufficient information is defined to include the following:

- The lateral and vertical extent of contamination at levels exceeding the FAL

- The information needed to predict potential remediation waste types and volumes

- Any other information needed to evaluate the feasibility of remediation alternatives

For radiological contaminants, the presence of contamination at levels exceeding the FAL is defined as the condition where the most exposed worker has the potential to receive a TED of at least $25 \mathrm{mrem} / \mathrm{yr}$. The DQO process resulted in an assumption that corrective action is required within any area exhibiting HCA conditions. Therefore, DCBs were established for areas exceeding HCA criteria (Section 3.4).

For shaft safety experiments where contamination vented to the surface, the DQO process resulted in an assumption that TED within the subsurface (chimney) of the emplacement holes at these locations exceeds the FAL and requires corrective action. Therefore, a DCB was established for each of these locations (Section 3.4). Figure 3-2 shows the DCBs for CAU 568. Therefore, Decision I for the DCBs 
is resolved and a corrective action is necessary. Decision I will be resolved for the area outside the DCBs.

For Study Groups 1, 3, 4, and 5, Decision I samples will be submitted to analytical laboratories to determine the presence of a COC. If a COC is present, Decision II samples for these study groups will be submitted to define the extent of COC contamination. In addition, samples will be submitted for analyses, as needed, to support waste management or health and safety decisions. For Study Group 2, the presence of radioactivity above background will be used to determine the presence of a COC.

A corrective action may also be required if a combination of contaminants is determined to jointly pose an unacceptable risk or if PSM is identified as described in the Soils RBCA document (NNSA/NFO, 2013).

If sufficient information is not available to resolve Decision II, then site conditions will be reevaluated and additional samples will be collected (as long as the scope of the investigation is not exceeded and any CSM assumption has not been shown to be incorrect).

\section{A.3.2 Alternative Actions to the Decisions}

This section identifies actions that may be taken to solve the problem depending on the possible outcomes of the investigation.

\section{A.3.2.1 Alternative Actions to Decision I}

If no COC associated with a release is detected, further assessment of the release is not required. If a COC associated with a release is detected, the extent of COC contamination will be determined and additional information required to evaluate potential CAAs will be collected.

\section{A.3.2.2 Alternative Actions to Decision II}

If the lateral and vertical extent of COC contamination have not been defined for radiological contamination, then additional samples will be collected until an $\mathrm{r}^{2}$ greater than 0.8 can be established between TED values and radiation survey values. If a valid correlation cannot be established using 
this criterion, the lateral and vertical extent of COC contamination will be defined by bounding locations where the TED is less than the FAL.

If the lateral and vertical extent of COC contamination have not been defined for chemical COCs, then additional bounding samples will be collected.

If sample analytical results are not sufficient to predict potential remediation waste types, then additional waste characterization samples will be collected. If available information is not sufficient to evaluate the potential for migration of COC contamination beyond the corrective action boundary, then additional information will be collected. If sufficient information is not available to evaluate potential CAAs, then additional samples will be collected. Otherwise, collection of additional information is not required. 


\section{A.4.0 Step 3 - Identify Information Inputs}

Step 3 of the DQO process identifies the information needed, determines sources for information, and identifies sampling and analysis methods that will allow reliable comparisons with FALs.

\section{A.4.1 Information Needs}

To resolve Decision I (determine whether contamination from the release is present at levels exceeding a FAL) for the areas outside the DCBs, samples will be collected and analyzed following these two criteria:

- Samples must either (a) be collected in areas most likely to contain a COC (judgmental sampling) or (b) properly represent contamination at the release (probabilistic sampling).

- The analytical suite selected must be sufficient to identify any COC present in the samples.

The extent of COC contamination portion of Decision II will be resolved using one of the following methods:

- Method 1. TED rates need to be established at locations where the TED values bound the FAL dose rate and provide sufficient information to establish an $\mathrm{r}^{2}$ greater than 0.8 between TED values and radiation survey values. A boundary will then be determined around the radiation survey isopleth that correlates to the 25-mrem/yr FAL.

- Method 2. The lateral and vertical extent of COC contamination will be defined by sample results from locations contiguous to the contamination where TED or COC concentrations are less than the FAL.

- Method 3. The lateral and vertical extent of COC contamination will be defined by the entire lateral and vertical extent of a material with clearly identifiable physical properties that is assumed to be entirely contaminated at levels exceeding the FAL. 
If additional information is needed to evaluate CAAs, samples will be collected and analyzed to meet the following criteria:

- Samples of the waste or soil must provide sufficient information to determine potential remediation waste types.

- Samples of the waste must provide sufficient information to determine whether the waste is PSM.

\section{A.4.2 Sources of Information}

Information to satisfy Decision I and Decision II will be generated by collecting environmental samples. These samples will be submitted to analytical laboratories meeting the quality criteria stipulated in the Soils QAP (NNSA/NSO, 2012). TLDs will be submitted to the Environmental Technical Services group at the NNSS, which is certified by the DOE Laboratory Accreditation Program for dosimetry. Only validated data from analytical laboratories will be used to make DQO decisions. Sample collection and handling activities will follow standard procedures.

\section{A.4.2.1 Sample Locations}

Design of the sampling approaches for the CAU 568 releases must ensure that the data collected are sufficient for selection of the CAAs (EPA, 2002). To meet this objective, the samples collected from each site should either be from locations that most likely contain a COC, if present (judgmental), or from locations that properly represent overall contamination at the release (probabilistic). These sample locations, therefore, can be selected by means of either (a) biasing factors used in judgmental sampling (e.g., a stain, likely containing a spilled substance) or (b) randomly using a probabilistic sampling design. The implementation of a judgmental approach for sample location selection, and of a probabilistic sampling approach, for CAU 568 are discussed in Section A.8.0.

\section{A.4.2.2 Analytical Methods}

Analytical methods are available to provide the data needed to resolve the decision statements. The analytical methods and laboratory requirements (e.g., precision, and accuracy) for soil samples are provided in the Soils QAP (NNSA/NSO, 2012). 


\section{A.5.0 Step 4 - Define the Boundaries of the Study}

Step 4 of the DQO process defines the target population of interest and its relevant spatial boundaries, specifies temporal and other practical constraints associated with sample/data collection, and defines the sampling units on which decisions or estimates will be made.

\section{A.5.1 Target Populations of Interest}

The population of interest to resolve Decision I (determine whether a COC from the release is present) is TED or contaminant concentrations exceeding a FAL at any location or area within the release. The populations of interest to resolve Decision II (If corrective action is required, is sufficient information available to evaluate potential CAAs?) are as follows:

- For radiological contamination, TED and corresponding radiation survey values from locations where TED varies from above the FAL to below the FAL

- For chemical contamination, COC concentrations for each one of a set of locations bounding contamination in lateral and vertical directions

- Investigation waste and potential remediation waste characteristics

\section{A.5.2 Spatial Boundaries}

Spatial boundaries are the maximum lateral and vertical extent of expected contamination that can be supported by the CSM. These boundaries were agreed to in the DQO meeting with decision makers. Decision II spatial boundaries are as follows:

\section{- Vertical (below current ground surface)}

- $5 \mathrm{~cm}$ for atmospheric deposition (Study Groups 1, 2, and 3)

- $3 \mathrm{ft}$ for windrow area (Study Group 1)

- 15 ft (Study Groups 4 and 5)

\section{- Lateral}

- 1 mi from release (Study Groups 1 and 5)

- Boundary of the crater/potential crater area (Study Group 2)

- $1 / 2$ mi from release (Study Group 3)

- $15 \mathrm{ft}$ from release (Study Group 4) 
Contamination found beyond these boundaries may indicate a flaw in the CSM and may require reevaluation of the CSM before the investigation can continue. Each release is considered geographically independent, and intrusive activities are not intended to extend into the boundaries of neighboring releases.

\section{A.5.3 Practical Constraints}

Practical constraints (e.g., activities by other organizations at the NNSS, utilities, threatened or endangered animals and plants, unstable or steep terrain, and/or access restrictions) may affect the ability to investigate this site. Practical constraints that have been identified specific to CAU 568 include the presence of multiple subsidence craters/potential crater areas from underground testing that was conducted in the area.

\section{A.5.4 Define the Sampling Units}

The scale of decision making refers to the smallest, most appropriate area or volume for which decisions will be made. The scale of decision making in Decision I is each release. The presence of a COC associated with a release will cause the determination that the release requires further evaluation. For the windrow area, the scale of decision making is the entire windrow area. The scale of decision making for Decision II for all study groups is defined as a contiguous area containing a COC originating from the release. Resolution of Decision II requires this contiguous area to be bounded laterally and vertically. 


\section{A.6.0 Step 5 - Develop the Analytic Approach}

Step 5 of the DQO process specifies appropriate population parameters for making decisions, defines action levels, and generates a decision rule.

\section{A.6.1 Population Parameters}

Population parameters are defined for judgmental and probablistic sampling designs in the following subsections. Population parameters are the parameters compared to action levels.

\section{A.6.1.1 Judgmental Sampling Design}

The judgmental design will be implemented as described in the Soils RBCA document (NNSA/NFO, 2013). For chemical contaminants, the population parameter is the observed concentration of each contaminant from each individual analytical sample. For radiological contaminants, the population parameter is the calculated TED from each location. Each sample result will be compared to the FALs to determine the appropriate resolution to Decision I and Decision II. A single sample result for any contaminant exceeding a FAL would cause a determination that a corrective action is required (for Decision I), or that the extent of COC contamination is not bounded (for Decision II).

If good prior information about the target site of interest is available, then the sampling may be designed to collect samples only from areas known to have the highest concentration levels on the target site. If the observed concentrations from these samples are below the action level, then a decision can be made that the site contains safe levels of the contaminant without the samples being truly representative of the entire area (EPA, 2006).

\section{A.6.1.2 Probabilistic Sampling Design}

For probabilistic sampling results, the population parameter is the true TED over the area of the sample plot. Resolution of DQO decisions associated with the probabilistic sampling design requires determining, with a specified degree of confidence, whether the true TED at the site in question exceeds the FAL. Because a calculated TED is an estimate of the true (unknown) TED, it is uncertain how well the calculated TED represents the true TED. If the calculated TED were significantly 
different than the true TED, a decision based on the calculated TED could result in a decision error. To reduce the probability of making a false-negative decision error, a conservative estimate of the true TED is used instead of the calculated TED. This conservative estimate (overestimation) of the true TED will be calculated as the 95 percent UCL of the average TED values (Section 4.1). By definition, there will be a 95 percent probability that the true TED is less than the 95 percent UCL of the calculated TED.

The computation of appropriate confidence limits will be accomplished as described in the Soils RBCA document (NNSA/NFO, 2013). For Decision I probabilistic decisions, the 95 percent UCL will be used to compare with the FAL. For Decision II probabilistic decisions, the 95 percent LCL of the regression will be used to determine the radiological survey value that corresponds to 25-mrem/yr TED.

\section{A.6.2 Action Levels}

The PALs presented in this section are to be used for site screening purposes. They are not necessarily intended to be used as cleanup action levels or FALs. However, they are useful in screening out contaminants that are not present in sufficient concentrations to warrant further evaluation and, therefore, streamline the consideration of remedial alternatives.

The FALs will be established using the RBCA process described in the Soils RBCA document (NNSA/NFO, 2013). This process conforms with NAC 445A.227, which lists the requirements for sites with soil contamination (NAC, 2012a). For the evaluation of corrective actions, NAC 445A.22705 (NAC, 2012b) requires the use of ASTM Method E1739 (ASTM, 1995) to "conduct an evaluation of the site, based on the risk it poses to public health and the environment, to determine the necessary remediation standards or to establish that corrective action is not necessary.” For the evaluation of corrective actions, the FALs are established as the necessary remedial standard. The RBCA process as described in the Soils RBCA document (NNSA/NFO, 2013) defines three tiers (or levels) of evaluation involving increasingly sophisticated analyses.

The comparison of laboratory results to FALs and the evaluation of potential corrective actions will be included in the investigation report. The FALs will be defined (along with the basis for their definition) in the investigation report. 


\section{A.6.2.1 Chemical PALs}

Except as noted herein, the chemical PALs are defined as the Region 9 Regional Screening Levels for chemical contaminants in industrial soils (EPA, 2013a). Background concentrations for RCRA metals will be used instead of screening levels when natural background concentrations exceed the screening level (e.g., arsenic on the NNSS). Background is considered the average concentration plus two standard deviations of the average concentration for sediment samples collected by the Nevada Bureau of Mines and Geology throughout the Nevada Test and Training Range (formerly the Nellis Air Force Range) (NBMG, 1998; Moore, 1999). For detected chemical COPCs without established screening levels, the protocol used by EPA Region 9 in establishing screening levels (or similar) will be used to establish PALs. If used, this process will be documented in the investigation report.

\section{A.6.2.2 Radionuclide PALs}

The PAL for radioactive contaminants is a TED of $25 \mathrm{mrem} / \mathrm{yr}$, based upon the Industrial Area exposure scenario. The Industrial Area exposure scenario is described in Soils RBCA document (NNSA/NFO, 2013).

\section{A.6.3 Decision Rules}

The decision rules applicable to both Decision I and Decision II are as follows:

- If contamination levels are inconsistent with the CSM or extends beyond the spatial boundaries identified in Section A.5.2, then work will be suspended and the investigation strategy will be reconsidered, else the decision will be to continue sampling.

The decision rules for Decision I are as follows:

- If the population parameter of any COPC in the Decision I population of interest (defined in Step 4) exceeds the corresponding FAL, then Decision II will be resolved and a corrective action will be determined, else no further action will be necessary for that COPC in that population.

- If a waste is present that, if released, has the potential to cause future soil contamination at levels exceeding a FAL, then a corrective action will be determined, else no further action will be necessary. 
The decision rules for Decision II are as follows:

- If the spatial extent of any COC has not been defined, then additional samples will be collected, else no further investigation will be necessary.

- If sufficient information is not available to determine potential remediation waste types and evaluate the feasibility of remediation alternatives, additional waste characterization samples will be collected, else no further investigation will be necessary. 


\section{A.7.0 Step 6 - Specify Performance or Acceptance Criteria}

Step 6 of the DQO process defines the decision hypotheses, specifies controls against false rejection and false acceptance decision errors, examines consequences of making incorrect decisions from the test, and places acceptable limits on the likelihood of making decision errors.

\section{A.7.1 Decision Hypotheses}

The baseline condition (i.e., null hypothesis) and alternative condition for Decision I are as follows:

- Baseline condition. A COC is present.

- Alternative condition. A COC is not present.

The baseline condition (i.e., null hypothesis) and alternative condition for Decision II are as follows:

- Baseline condition. The extent of a COC has not been defined.

- Alternative condition. The extent of a COC has been defined.

Decisions and/or criteria have false-negative or false-positive errors associated with their determination. The impact of these decision errors and the methods that will be used to control these errors are discussed in the following subsections. In general terms, confidence in DQO decisions based on judgmental sampling results will be established qualitatively by the following:

- Developing a CSM (based on process knowledge) that is agreed to by decision maker participants during the DQO process.

- Testing the validity of the CSM based on investigation results.

- Evaluating the quality of data based on DQI parameters.

\section{A.7.2 False-Negative Decision Error}

The false-negative decision error would mean deciding that a COC is not present when it actually is (Decision I), or deciding that the extent of a COC has been defined when it has not (Decision II). In both cases, the potential consequence is an increased risk to human health and environment. 


\section{A.7.2.1 False-Negative Decision Error for Judgmental Sampling}

In judgmental sampling, the selection of the number and location of samples is based on knowledge of the feature or condition under investigation and on professional judgment (EPA, 2002). Judgmental sampling conclusions about the target population depend upon the validity and accuracy of professional judgment.

The false-negative decision error (where consequences are more severe) for judgmental sampling designs is controlled by meeting these criteria:

- For Decision I, having a high degree of confidence that the sample locations selected will identify a COC if present anywhere within the release. For Decision II, having a high degree of confidence that the sample locations selected will identify the extent of a COC.

- Having a high degree of confidence that analyses conducted will be sufficient to detect any COC present in the samples.

- Having a high degree of confidence that the dataset is of sufficient quality and completeness.

To satisfy the first criterion, Decision I samples must be collected in areas most likely to be contaminated by a COC (supplemented by unbiased samples where appropriate). Decision II samples must be collected in areas that represent the lateral and vertical extent of contamination (above FALs). The following characteristics must be considered to control decision errors for the first criterion:

- Source and location of release

- Chemical nature and fate properties

- Physical transport pathways and properties

- Hydrologic drivers

These characteristics were considered during the development of the CSM and selection of sampling locations. The field-screening methods and biasing factors listed in Section A.4.2.1 will be used to further ensure that appropriate sampling locations are selected to meet these criteria. The investigation report will present an assessment on the DQI of representativeness that samples were collected from those locations that best represent the populations of interest as defined in Section A.5.1. 
To satisfy the second criterion, Decision I soil samples will be analyzed for the chemical and radiological parameters listed in Section 3.2. Decision II soil samples will be analyzed for unbounded COCs. The DQI of sensitivity will be assessed for all analytical results to ensure that all sample analyses had measurement sensitivities (detection limits) that were less than or equal to the corresponding FALs. If this criterion is not achieved, the affected data will be assessed (for usability and potential impacts on meeting site characterization objectives) in the investigation report.

To satisfy the third criterion, the entire dataset of soil sample results, as well as individual soil sample results, will be assessed against the DQIs of precision, accuracy, comparability, and completeness as defined in the Soils QAP (NNSA/NSO, 2012). The DQIs of precision and accuracy will be used to assess overall analytical method performance as well as to assess the need to potentially "flag" (qualify) individual contaminant results when corresponding QC sample results are not within the established control limits for precision and accuracy. Data qualified as estimated for reasons of precision or accuracy may be considered to meet the analyte performance criteria based on an assessment of the data. The DQI for completeness will be assessed to ensure that all data needs identified in the DQO have been met. The DQI of comparability will be assessed to ensure that all analytical methods used are equivalent to standard EPA methods so that results will be comparable to regulatory action levels that have been established using those procedures. Strict adherence to established procedures and QA/QC protocol protects against false negatives.

To provide information for the assessment of the DQIs of precision and accuracy, laboratory QC samples will be selected and analyzed in every batch of up to 20 samples per matrix.

\section{A.7.2.2 False-Negative Decision Error for Probabilistic Sampling}

The false-negative decision error rate goal was established by the DQO meeting participants at 5 percent. Upon validation of the analytical results, statistical parameters will be calculated for each significant COPC identified at each site. Protection against a false-negative decision error is contingent upon the following:

- Sample size

- Actual variability

- Measurement error 
Control of the false-negative decision error for probabilistic sampling designs is accomplished by ensuring that the following requirements are met for each of the significant COPCs:

- A sufficient sample size was collected (see Section A.8.1.3).

- The actual standard deviation is calculated.

- Analyses conducted were sufficient to detect contamination exceeding FALs.

\section{A.7.3 False-Positive Decision Error}

The false-positive decision error would mean deciding that a COC is present when it is not, or a COC is unbounded when it is not, resulting in increased costs for unnecessary sampling and analysis.

False-positive results are typically attributed to laboratory and/or sampling/handling errors that could cause cross contamination. To control against cross contamination, decontamination of sampling equipment will be conducted in accordance with established and approved procedures, and only clean sample containers will be used. To determine whether a false-positive analytical result may have occurred, the following QC samples will be collected (as established in the CAU 568 DQOs):

- Trip blanks (1 per sample cooler containing VOC environmental samples)

- $\quad$ Equipment rinsate blanks (1 per VOC sampling event

For probabilistic sampling, false-positive decision error rate goal was established by the DQO meeting participants at 0.20 (or 20 percent probability). Protection against this decision error is also afforded by the controls listed in Section A.7.2 for probabilistic sampling designs. 


\section{A.8.0 Step 7 - Develop the Plan for Obtaining Data}

Step 7 of the DQO process selects and documents a design that will produce data that exceed performance or acceptance criteria. For Study Groups 1, 2, and 3, additional TRSs will be completed during the CAI to assist in the placement of specific releases within study groups and the selection of sample locations.

Judgmental sampling schemes will be implemented to select sample plot locations for Study Group 1. Probabilistic sampling schemes will be implemented to select the sample locations within each of the sample plots. Judgmental sampling will also be used to investigate any newly discovered releases as described in Section A.2.2.1. Investigation results will be compared to FALs to determine the need for corrective action. PSM sample results will be evaluated against the PSM criteria listed in Section A.3.1 to determine the need for corrective action.

If sufficient sample material cannot be collected at a specified surface soil sample location (e.g., rock, caliche, or buried concrete), the Site Supervisor will establish the location at the nearest place that a surface sample can be obtained. A TLD will be placed at each sample location to measure the external dose.

\section{A.8.1 Study Group 1 (Releases within a Defined Radiological Signature)}

A judgmental sampling design will be implemented for locating sample plots for Study Group 1 outside the DCBs.

A probabilistic sampling scheme will be implemented to select sample locations within the sample plots and evaluate the analytical results. For each sample collected within the sample plot, unbiased subsample locations will be chosen based on a random start, triangular pattern (see Figure A.8-3 for an example of this sampling scheme). If sufficient sample material cannot be collected at a specified location (e.g., rock, caliche, or buried concrete), the sample will be collected from the nearest location that a surface sample can be obtained. A TLD will be placed in the center of each sample plot to measure the external dose. 


\section{A.8.1.1 Decision I Sample Selection}

Decision I sample plot locations will be determined within each area with a defined radiological survey signature based on the highest results of the TRSs. This will be done in an effort to find the locations where TED is the highest. Figures A.8-1 and A.8-2 show the Decision I sample plot locations that have been identified for the Otero and San Juan release area and the Chavez release area based on the completed radiological surveys. These locations will be refined when additional surveys are conducted during the CAI.

\section{A.8.1.2 Decision II Sample Selection}

Decision II sample plot locations, if necessary, will be selected judgmentally based on TRSs and/or aerial radiological surveys. These data will be used to establish a correlation of TED to radiation survey values. Three Decision II sample plots will be established judgmentally along each of two vectors that are approximately normal to the radiation survey isopleths with the constraint that, on each vector, at least one sample plot will present a TED less than the FAL. The Decision II sample plot locations for the Otero and San Juan area are shown on Figure A.8-1. The Decision II sample plot locations for the Chavez area are shown on Figure A.8-2.

The identified sample plot locations may be adjusted based on real-time radiological instrument readings, or if the plot is located in an area where sufficient samples cannot be obtained (e.g., located within a disturbed area, shrubs, or boulders present obscuring sample locations).

\section{A.8.1.3 Determination of Buried Contamination}

As the CSM includes the possibility of buried contamination within the windrow area, it will be determined whether buried contamination exists. Because two Decision II sample plots within the San Juan and Otero radiological signature will be situated within the windrow area, these two plots will be investigated for subsurface contamination. See Figure A.8-1 for the suggested locations of the sample plots within the windrow area that will be investigated for subsurface contamination. These locations will be adjusted based on the results of additional surveys conducted during the CAI. Soil 


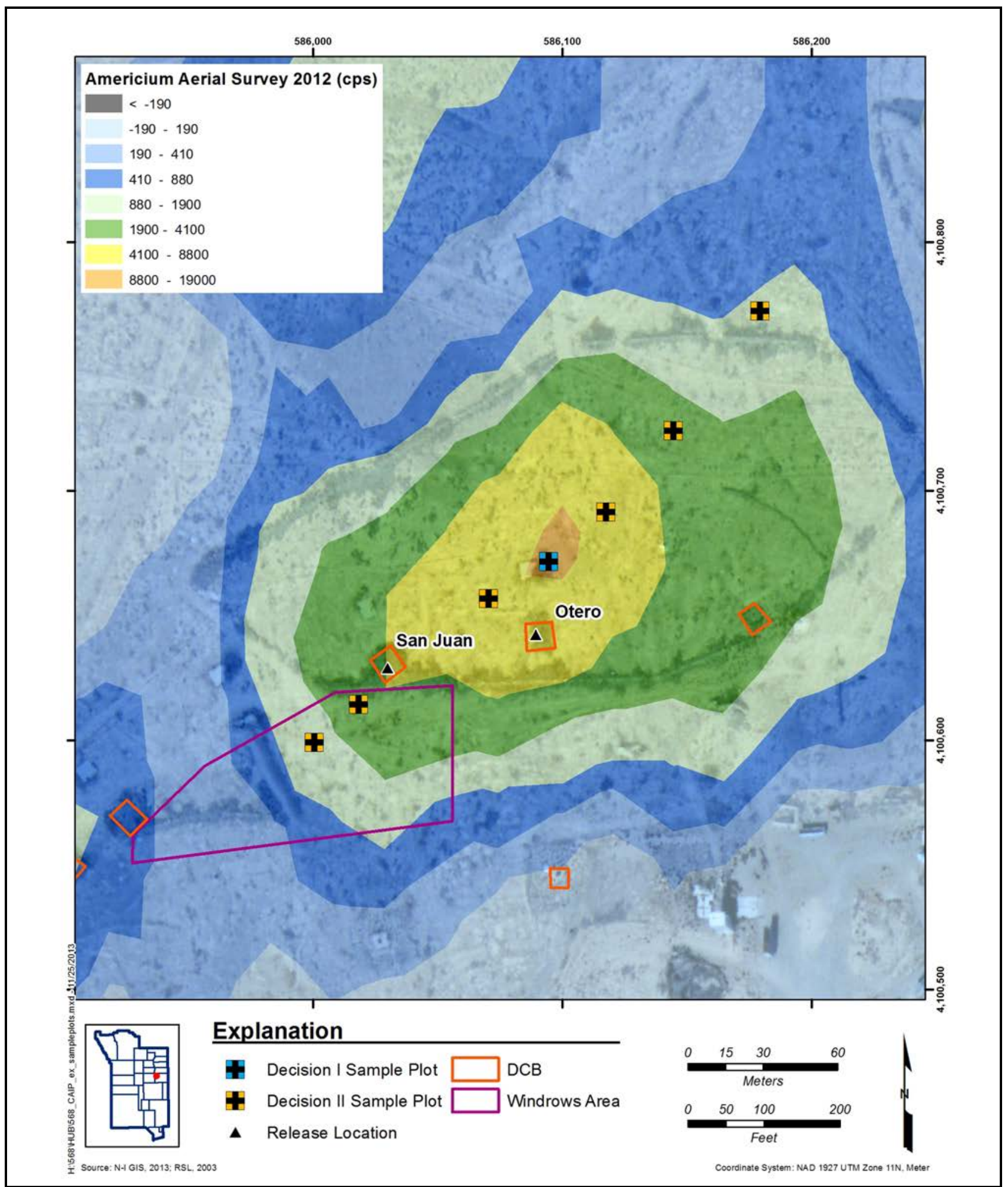

Figure A.8-1

CAU 568 Sample Plot Locations for Study Group 1 (Otero and San Juan Release Area) 


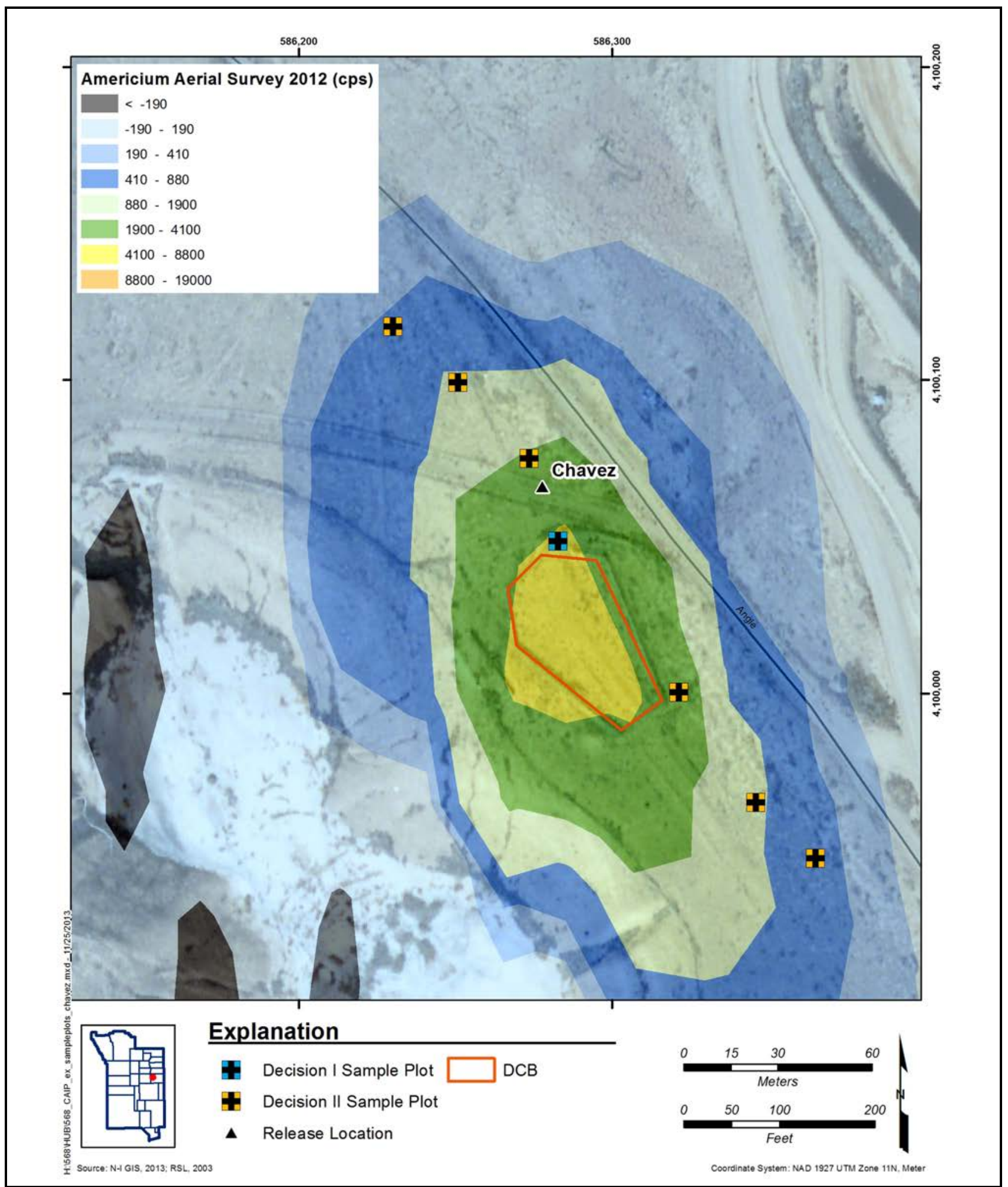

Figure A.8-2

CAU 568 Sample Plot Locations for Study Group 1 (Chavez Release Area) 


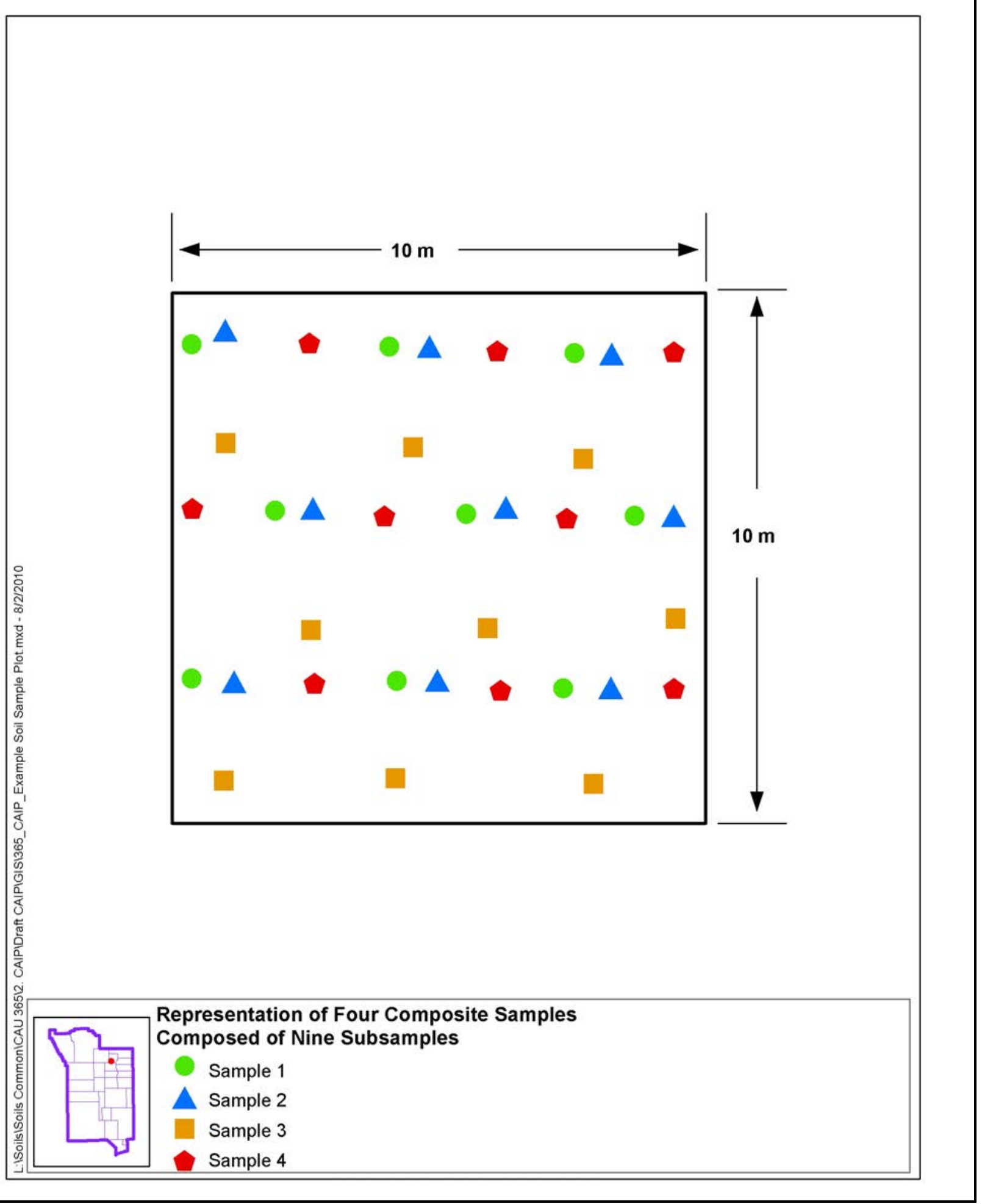

Figure A.8-3

Sample Plot Sample Collection Layout 
will be evaluated for subsurface contamination at either the center or corner of the sample plot. The subsurface soil grab samples will be evaluated in the following manner:

- A 5-cm layer of soil will be removed from the sample location.

- The surface sample will be screened with alpha/beta contamination meter.

- Subsequent intervals will be sampled until native soil is encountered.

It will be assumed that buried contamination exists, and a subsurface sample will be collected if subsurface screening results are greater than the FSLs and greater than 20 percent of the surface screening results. If subsurface screenings do not meet these criteria, no subsurface samples will be collected. If more than one subsurface interval exceeds these criteria, only the sample with the greatest exceedance of screening results will be submitted for analysis.

If buried contamination exists above FALs, it will be conservatively assumed that the COC may be present anywhere within the windrow area. Therefore, a corrective action will be required for the entire windrow area. The samples with the highest radiological dose (surface or subsurface) at each location will be used for the internal dose estimate. If buried contamination exists, a TLD-equivalent external dose will be calculated for the subsurface sample by establishing a correlation between RESRAD-calculated external dose from surface samples and the RESRAD-calculated external dose from the subsurface samples. This surface TLD reading will be adjusted by this proportion to estimate a TLD-equivalent external dose for the subsurface soil as described in the Soils RBCA document (NNSA/NFO, 2013).

\section{A.8.2 Study Group 2 (Releases Located within a Crater or Potential Crater Area That Cannot Be Entered)}

Study Group 2 consists of test releases located within a crater or potential crater area that cannot be entered. These releases will be evaluated using the subsidence crater strategy in the Soils RBCA document (NNSA/NFO, 2013). TRSs will be conducted around each crater or potential crater area fence line at identified releases. If radioactivity above background is not identified, no further action will be required for the release. If radioactivity above background is identified, the entire crater or potential crater area will be included in a corrective action boundary. Additionally, if contamination extends beyond the crater or potential crater boundary, it will be sampled in accordance with 
Study Group 1. See Section A.8.1 for the sampling plan if contamination extends beyond the crater or potential crater boundary.

\section{A.8.3 Study Group 3 (Releases with no Radiological Signature)}

\section{A.8.3.1 Decision I Sample Selection}

Decision I sampling will be conducted to verify a dose above FALs is not present at the release.

TRS data will be collected for this Study Group outside the DCBs. A Decision I grab sample will be determined judgmentally within each release based on either the location of the highest radiological survey or biased to an undisturbed location nearest to the GZ. This will be done in an effort to find the location where TED is highest. Individual sample results, rather than an average concentration, will be used to compare to FALs.

\section{A.8.3.2 Decision II Sample Selection}

If it is determined that Decision II sampling is necessary to bound contamination at this release, Decision II planning will be conducted with the stakeholders.

\section{A.8.4 Study Group 4 (Spills and Debris)}

Sample locations for releases identified in Study Group 4 will be determined based upon the likelihood of a contaminant release at each location. These locations will be selected based on the identification of biasing factors during the investigation. These biasing factors may include the following:

- Stains. Any spot or area on the soil surface that may indicate the presence of a potentially hazardous liquid. Typically, stains indicate an organic liquid, such as an oil, has reached the soil and may have spread out vertically and laterally.

- Radiological survey anomalies. Radiological survey results that are significantly higher than the surrounding area.

- Geophysical anomalies. Geophysical survey results that are not consistent with the surrounding area (e.g., results indicating buried concrete or metal, surface metallic objects). 
- Drums, containers, equipment, or debris. Materials that contain or may have contained hazardous or radioactive substances.

- $\quad$ Preselected areas based on process knowledge of the site. Locations for which evidence such as historical photographs, experience from previous investigations, or input from interviewee(s) exists that a release of hazardous or radioactive substances may have occurred.

- $\quad$ Preselected areas based on process knowledge of the contaminant(s). Locations that may reasonably have received contamination, selected on the basis of the chemical and/or physical properties of the contaminant(s) in that environmental setting.

- $\quad$ Other biasing factors. Factors not previously defined for the CAI that become evident during the CAI.

\section{A.8.4.1 Decision I Sample Selection}

A judgmental sampling design will be implemented for the Study Group 4 releases to establish locations and evaluate sample results. Individual sample results, rather than an average concentration, will be used to compare to FALs. Therefore, statistical methods to generate site characteristics will not be needed.

Currently, PSM and debris (including a transformer and lead items) have been identified as Study Group 4 releases (Figure A.8-4) and require corrective action. If necessary, Decision I samples will be collected from soil that presents the greatest degree of the biasing factor identified (surface or subsurface). Specific analyses will be requested based on the nature of the potential release (e.g., RCRA metal analysis at a lead-acid battery PSM location).

\section{A.8.4.2 Decision II Sample Selection}

Decision II judgmental samples will be collected from locations where a COC was detected. In general, sample locations will be arranged in a triangular pattern around the area containing a COC at distances based on site conditions, process knowledge, and biasing factors. If a COC extends beyond the initial step-outs, Decision II samples will be collected from incremental step-outs. Initial step-outs will be at least as deep as the vertical extent of contamination defined at the Decision I location and the depth of the incremental step-outs will be based on the deepest contamination observed at any location within the release. A clean sample (i.e., contamination levels less than FALs) collected from each step-out direction (lateral or vertical) will define extent of contamination in that direction. 


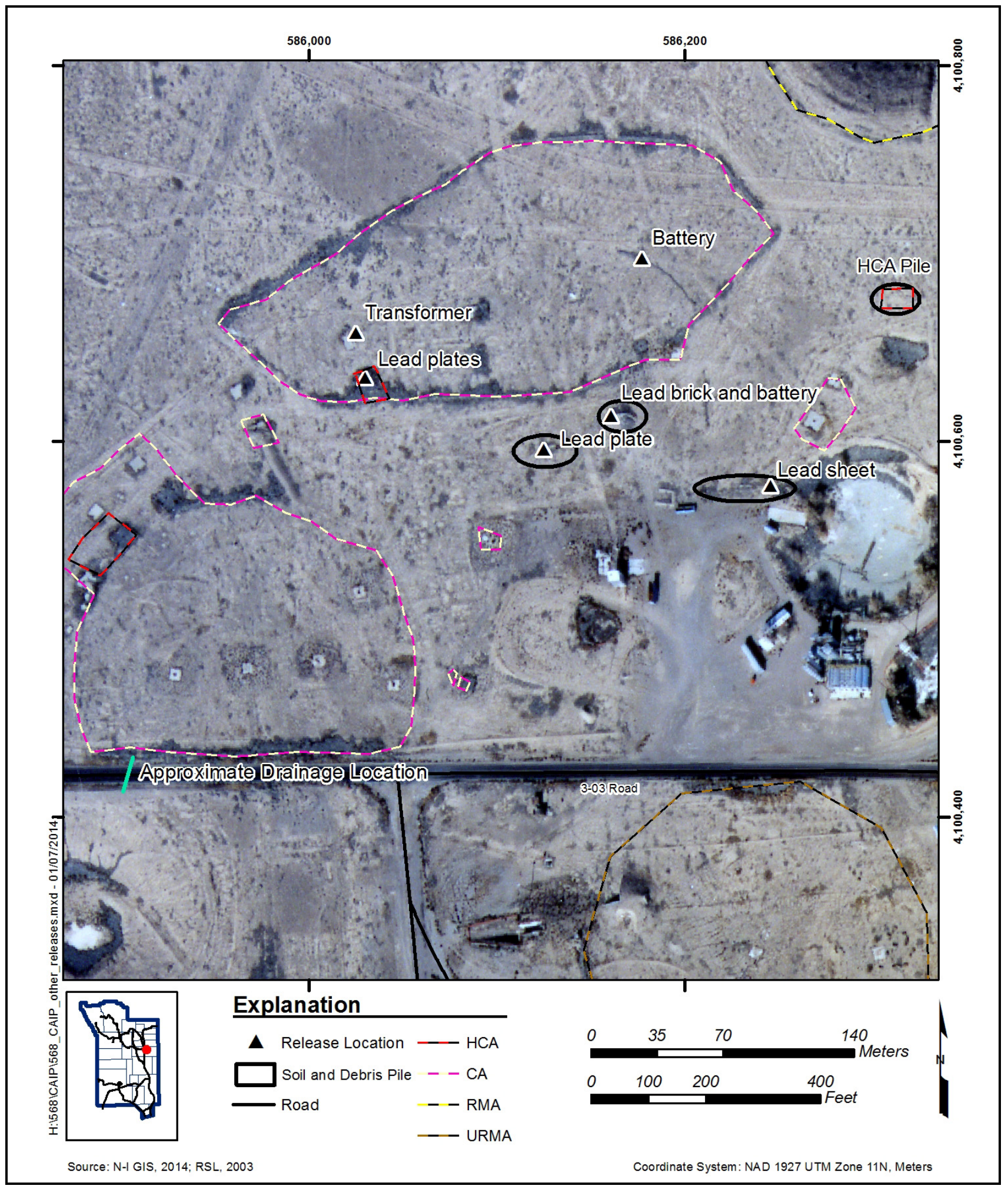

Figure A.8-4

Study Group 4 PSM and Debris Locations 


\section{A.8.5 Study Group 5 (Drainages)}

The migration of contamination at Study Group 5 is most likely to occur due to surface runoff in drainages from the study area. A small drainage that has formed as a result of recent precipitation events near the 3-03 Road will be investigated. The approximate location of this drainage is shown on Figure A.8-4. If other drainages leaving the site are identified during the CAI, they will also be investigated.

\section{A.8.5.1 Decision I}

For the investigation of drainages, sample locations will be selected from the center of sediment collection areas and/or at locations of elevated radiological readings within the sedimentation accumulation areas. Judgmental samples will be collected as follows:

- At each sample location within the sediment accumulation area, a sample will be collected from each 5-cm depth interval until native material is encountered.

- $\quad$ Each sample will be field screened with an alpha/beta contamination meter and compared to the established background FSL for the site.

- If the depth sample with the highest FSR is not significantly different (at least 20 percent difference) than the FSR of the surface sample, then only the surface sample will be submitted for analysis. If the FSR is greater than 20 percent higher than the surface sample, then both the surface sample and the depth sample with the elevated FSR will be submitted for analysis.

- If the FSL is not exceeded in any depth sample, then only the surface sample will be submitted for analysis.

- A TLD will be placed at each sample location.

It will be conservatively assumed that the highest TED from either surface or subsurface samples will be used to resolve DQO decisions. If buried contamination exists (as defined in Section A.8.1.3), a TLD-equivalent external dose will be calculated for the subsurface sample. This will be accomplished by establishing a correlation between RESRAD-calculated external dose from surface samples and the RESRAD-calculated external dose from the subsurface samples. This surface TLD reading will be increased by this proportion to estimate a TLD-equivalent external dose for the subsurface soil. 
All drainage samples will be submitted for the analyses listed under Study Group 5 in Table A.2-3. Information (such as sample results and the results of the radiological survey) needed to assess the potential for future migration of the 25-mrem/yr boundary will be obtained during the field investigation and addressed in the investigation report. If any additional drainages are identified during the investigation that have a potential to contain a COC, they will be evaluated as necessary.

\section{A.8.5.2 Decision II}

If a contamination level exceeding a FAL is found at a sediment accumulation area sample location, additional sedimentation areas will be sampled until at least two consecutive sedimentation areas are found that do not contain contamination levels exceeding a FAL. Decision II will be resolved by the assumption that the entire volume of sediment in each sediment accumulation area where a contamination level exceeding a FAL was identified exceeds the FAL. 


\section{A.9.0 References}

ASTM, see ASTM International.

ASTM International. 1995 (reapproved 2010). Standard Guide for Risk-Based Corrective Action Applied at Petroleum Release Sites, ASTM E1739 - 95(2010)e1. West Conshohocken, PA.

Bryant, E.A. 1992. The Cambric Migration Experiment, A Summary Report, LA-12335-MS. Los Alamos, NM: Los Alamos National Laboratory.

DOE, see U.S. Department of Energy.

DOE/NV, see U.S. Department of Energy, Nevada Operations Office.

EPA, see U.S. Environmental Protection Agency.

Hevesi, J.A., A.L. Flint, and L.E. Flint. 2003. Simulation of Net Infiltration and Potential Recharge Using a Distributed-Parameter Watershed Model of the Death Valley Region, Nevada and California, Water-Resources Investigations Report 03-4090. Sacramento, CA: U.S. Geological Survey.

Hoffman, D.C., and W.R. Daniels. 1984. "Assessment of the Potential for Radionuclide Migration from a Nuclear Explosion Cavity.” In Groundwater Contamination, pp. 139-146. Washington, DC: National Academy Press.

Moore, J., Science Applications International Corporation. 1999. Memorandum to M Todd (SAIC) titled "Background Concentrations for NTS and TTR Soil Samples," 3 February. Las Vegas, NV: IT Corporation.

NAC, see Nevada Administrative Code.

NBMG, see Nevada Bureau of Mines and Geology.

N-I GIS, see Navarro-Intera Geographic Information Systems.

NNSA/NFO, see U.S. Department of Energy, National Nuclear Security Administration Nevada Field Office.

NNSA/NSO, see U.S. Department of Energy, National Nuclear Security Administration Nevada Site Office.

Navarro-Intera Geographic Information Systems. 2013. ESRI ArcGIS Software. 
Navarro-Intera Geographic Information Systems. 2014. ESRI ArcGIS Software.

Nevada Administrative Code. 2012a. NAC 445A.227, “Contamination of Soil: Order by Director for Corrective Action; Factors To Be Considered in Determining Whether Corrective Action Required.” Carson City, NV. As accessed at http://www.leg.state.nv.us/nac on 8 October 2013.

Nevada Administrative Code. 2012b. NAC 445A.22705, “Contamination of Soil: Evaluation of Site by Owner or Operator; Review of Evaluation by Division.” Carson City, NV. As accessed at http://www.leg.state.nv.us/nac on 8 October 2013.

Nevada Bureau of Mines and Geology. 1998. Mineral and Energy Resource Assessment of the Nellis Air Force Range, Open-File Report 98-1. Reno, NV.

RSL, see Remote Sensing Laboratory.

Remote Sensing Laboratory. 2003. Aerial Photograph “NNSA-RSL_11189-46,” 4 December. Las Vegas, NV.

SNJV, see Stoller-Navarro Joint Venture.

Soule, D.A. 2006. Climatology of the Nevada Test Site, SORD Technical Memorandum 2006-03. Silver Spring, MD: National Oceanographic and Atmospheric Administration, Air Resources Laboratory.

Stoller-Navarro Joint Venture. 2007. Phase I Contaminant Transport Parameters for the Groundwater Flow and Contaminant Transport Model of Corrective Action Unit 97: Yucca Flat/Climax Mine, Nevada Test Site, Nye County, Nevada, Rev. 0, S-N/99205--096. Las Vegas, NV.

USGS, see U.S. Geological Survey.

U.S. Department of Energy. 1997. The Procedures Manual of the Environmental Measurements Laboratory, HASL-300, 28th Ed., Vol. I. February. New York, NY.

U.S. Department of Energy, National Nuclear Security Administration Nevada Field Office. 2013. Soils Risk-Based Corrective Action Evaluation Process, DOE/NV--1475-ROTC 2. Las Vegas, NV.

U.S. Department of Energy, National Nuclear Security Administration Nevada Site Office. 2012. Soils Activity Quality Assurance Plan, Rev. 0, NNSA/NSO--1478. Las Vegas, NV.

U.S. Department of Energy, Nevada Operations Office. 1992. Remedial Investigation and Feasibility Study for the Plutonium Contaminated Soils at Nevada Test Site, Nellis Air Force Range and Tonopah Test Range. April. Las Vegas, NV. 
U.S. Department of Energy, Nevada Operations Office. 1996. Final Environmental Impact Statement for the Nevada Test Site and Off-Site Locations in the State of Nevada, DOE/EIS 0243.

Las Vegas, NV.

U.S. Department of Energy, Nevada Operations Office. 2000. United States Nuclear Tests, July 1945 through September 1992, DOE/NV--209-REV 15. Las Vegas, NV.

U.S. Environmental Protection Agency. 2002. Guidance for Quality Assurance Project Plans, EPA QA/G5, EPA/240/R-02/009. Washington, DC: Office of Environmental Information.

U.S. Environmental Protection Agency. 2006. Guidance on Systematic Planning Using the Data Quality Objectives Process, EPA QA/G-4, EPA/240/B-06/001. Washington, DC: Office of Environmental Information.

U.S. Environmental Protection Agency. 2013a. Pacific Southwest, Region 9: Regional Screening Levels (Formerly PRGs), Screening Levels for Chemical Contaminants. As accessed at http://www.epa.gov/region9/superfund/prg on 8 October. Prepared by EPA Office of Superfund and Oak Ridge National Laboratory.

U.S. Environmental Protection Agency. 2013b. SW-846, Test Methods for Evaluating Solid Waste, Physical/Chemical Methods. As accessed at http://www.epa.gov/epawaste/hazard/testmethods/sw846 on 8 October.

U.S. Geological Survey. 2013. “Groundwater Levels for Nevada.” As accessed at http://nwis.waterdata.usgs.gov/nv/nwis/gwlevels on 9 September.

van Genuchten, M. Th. 1980. “A Closed-Form Equation for Predicting the Hydraulic Conductivity of Unsaturated Soils.” In Soil Science Society of America Journal, Vol. 44(5): pp. 892-898.

Madison, WI.

Yucel, V. National Security Technologies, LLC. 2009. Personal communication to R.L. Kidman (N-I) regarding PET data, 30 April. Las Vegas, NV. 


\section{Appendix B}

\section{Activity Organization}




\section{B.1.0 Activity Organization}

The NNSA/NFO Soils Activity Lead is Tiffany Lantow. She can be contacted at (702) 295-7645.

The identification of the activity Health and Safety Officer and the Quality Assurance Officer can be found in the appropriate plan. However, personnel are subject to change, and it is suggested that the NNSA/NFO Soils Activity Lead be contacted for further information. The Task Manager will be identified in the FFACO Monthly Activity Report prior to the start of field activities. 


\section{Appendix C}

Nevada Division of Environmental Protection Comments

(6 Pages) 


\section{Nevada Environmental Management Operations Activity DOCUMENT REVIEW SHEET}

\begin{tabular}{|c|c|c|c|c|c|c|}
\hline \multicolumn{2}{|c|}{ 1. Document Title/Number: } & \multicolumn{2}{|c|}{$\begin{array}{l}\text { Draft Corrective Action Investigatin Plan for Corrective Action Unit 568: Area } 3 \\
\text { Plutonium Dispersion Sites, Nevada National Security Site, Nevada }\end{array}$} & 2. Document Date: & \multicolumn{2}{|l|}{$12 / 4 / 2013$} \\
\hline \multicolumn{2}{|l|}{ 3. Revision Number: } & 0 & & 4. Originator/Organization: & \multicolumn{2}{|l|}{ Navarro-INTERA } \\
\hline \multicolumn{2}{|c|}{$\begin{array}{l}\text { 5. Responsible NNSA/NSO Activity } \\
\text { Lead: }\end{array}$} & \multicolumn{2}{|l|}{ Tiffany A. Lantow } & 6. Date Comments Due: & \multicolumn{2}{|l|}{$1 / 3 / 2014$} \\
\hline \multicolumn{2}{|l|}{ 7. Review Criteria: } & \multicolumn{2}{|l|}{ Full } & & & \\
\hline \multicolumn{2}{|c|}{ 8. Reviewer/Organization/Phone No: } & \multicolumn{2}{|l|}{ Jeff MacDougall / Scott Page, NDEP, 486-2850 - ext. 233 and 237} & 9. Reviewer's Signature: & & \\
\hline $\begin{array}{l}\text { 10. Comment } \\
\text { Number/Location }\end{array}$ & 11. Type* & 12. Comment & \multicolumn{3}{|c|}{ 13. Comment Response } & 14. Accept \\
\hline $\begin{array}{l}\text { 1.) Section 1.1.1, } \\
\text { Page 2, 3rd } \\
\text { Paragraph }\end{array}$ & Mandatory & $\begin{array}{l}\text { 2nd sentence: designate } 3-03 \text { Road on Figure } 1-1 \text { because } \\
\text { it was referred to in this section; suggest add globally to } \\
\text { related figures. }\end{array}$ & \multicolumn{3}{|c|}{ 3-03 Road was labeled on all applicable figures. } & \\
\hline $\begin{array}{l}\text { 2.) Section 1.1.2, } \\
\text { Page } 7,4 \text { th } \\
\text { Paragraph }\end{array}$ & Mandatory & $\begin{array}{l}\text { 2nd sentence: add brief assessment why documented rad } \\
\text { releases would not be reflected by survey. }\end{array}$ & \multicolumn{3}{|c|}{$\begin{array}{l}\text { A sentence was added to the end of the 4th paragraph } \\
\text { which reads, "Documented releases that were identified at } \\
\text { the time of the test were either short-lived radionuclides or } \\
\text { released at low concentrations such that the remaining } \\
\text { activities are insufficient to be detected by the aerial or } \\
\text { terrestrial radiological survey instruments." }\end{array}$} & \\
\hline $\begin{array}{l}\text { 3.) Section 1.1.2, } \\
\text { Page } 8 \text {, 3rd } \\
\text { Paragraph }\end{array}$ & Mandatory & $\begin{array}{l}\text { Add brief meaning of "removable contamination" in the } \\
\text { context of RBCA dose evaluation. }\end{array}$ & \multicolumn{3}{|c|}{$\begin{array}{l}\text { The following sentence was added following the first } \\
\text { sentence in the paragraph: "Removable contamination is } \\
\text { radioactive material that can be removed from surfaces by } \\
\text { nondestructive means such as casual contact, wiping, } \\
\text { brushing, or washing." }\end{array}$} & \\
\hline $\begin{array}{l}\text { 4.) Section 1.1.2, } \\
\text { Page } 8 \text {, 4th } \\
\text { Paragraph }\end{array}$ & Mandatory & $\begin{array}{l}\text { 1st sentence: add brief meaning of "test chimneys" in the } \\
\text { context of default contamination boundaries. }\end{array}$ & \multicolumn{3}{|c|}{$\begin{array}{l}\text { The beginning of the paragraph was edited and reads, } \\
\text { "DCBs will also be established for subsurface } \\
\text { contamination associated with underground safety } \\
\text { experiments that vented radioactivity to the soil surface. } \\
\text { Although it can be verified whether contamination on the } \\
\text { surface poses a risk to site workers, it is not feasible to } \\
\text { verify whether subsurface contamination along the venting } \\
\text { flow path is present and poses a risk to site workers." }\end{array}$} & \\
\hline
\end{tabular}




\section{Nevada Environmental Management Operations Activity DOCUMENT REVIEW SHEET}

\begin{tabular}{|c|c|c|c|c|c|c|}
\hline \multicolumn{2}{|c|}{ 1. Document Title/Number: } & \multicolumn{2}{|c|}{$\begin{array}{l}\text { Draft Corrective Action Investigatin Plan for Corrective Action Unit 568: Area } 3 \\
\text { Plutonium Dispersion Sites, Nevada National Security Site, Nevada }\end{array}$} & 2. Document Date: & \multicolumn{2}{|l|}{$12 / 4 / 2013$} \\
\hline \multicolumn{2}{|l|}{ 3. Revision Number: } & 0 & & 4. Originator/Organization: & \multicolumn{2}{|l|}{ Navarro-INTERA } \\
\hline \multicolumn{2}{|c|}{$\begin{array}{l}\text { 5. Responsible NNSA/NSO Activity } \\
\text { Lead: }\end{array}$} & \multicolumn{2}{|l|}{ Tiffany A. Lantow } & 6. Date Comments Due: & \multicolumn{2}{|l|}{$1 / 3 / 2014$} \\
\hline \multicolumn{2}{|l|}{ 7. Review Criteria: } & \multicolumn{2}{|l|}{ Full } & & & \\
\hline \multicolumn{2}{|c|}{ 8. Reviewer/Organization/Phone No: } & \multicolumn{2}{|l|}{ Jeff MacDougall / Scott Page, NDEP, 486-2850 - ext. 233 and 237} & 9. Reviewer's Signature: & & \\
\hline $\begin{array}{l}\text { 10. Comment } \\
\text { Number/Location }\end{array}$ & 11. Type* & 12. Comment & \multicolumn{3}{|c|}{ 13. Comment Response } & 14. Accept \\
\hline $\begin{array}{l}\text { 5.) Section } \\
\text { 2.2.10, Page 18, } \\
\text { 1st Paragraph }\end{array}$ & Mandatory & $\begin{array}{l}\text { Due to presence of surface lead items around GZs, add } \\
\text { brief assessment, based on available knowledge, for the } \\
\text { potential for subsurface lead items not noted during visual } \\
\text { surveys. }\end{array}$ & \multicolumn{3}{|c|}{$\begin{array}{l}\text { The fourth sentence in the paragraph has been revised and } \\
\text { reads, "Lead plates were identified on the surface of the GZ } \\
\text { pad for San Juan, within the HCA." Also, a sentence was } \\
\text { added between the 7th and 8th sentences in the paragraph } \\
\text { which reads, "It is assumed that additional lead items may } \\
\text { be present within any of the soil and debris piles." }\end{array}$} & \\
\hline $\begin{array}{l}\text { 6.) Section } 2.3 \text {, } \\
\text { Page } 18,1 \mathrm{st} \\
\text { Paragraph }\end{array}$ & Mandatory & $\begin{array}{l}\text { 3rd sentence: if the TSCA-regulated waste reference } \\
\text { specifically means polychlorinated biphenyls, (PCBs and/or } \\
\text { asbestos), then add PCBs and/or asbestos to the reference } \\
\text { (per Sec. 2.4.2). }\end{array}$ & \multicolumn{3}{|c|}{$\begin{array}{l}\text { "(polychlorinated biphenyls [PCBs])" was added following } \\
\text { "(TSCA) regulated wastes" in the last sentence of the } \\
\text { paragraph. }\end{array}$} & \\
\hline $\begin{array}{l}\text { 7.) Section 2.4.1, } \\
\text { Page 20, 2nd } \\
\text { Paragraph }\end{array}$ & Mandatory & $\begin{array}{l}\text { Based on available information, briefly summarize why } \\
\text { radiological contaminants are suspected at windrows. }\end{array}$ & \multicolumn{3}{|c|}{$\begin{array}{l}\text { The paragraph has been revised and reads, "Windrows } \\
\text { were created in } 1959 \text { within the area of Study Group } 1 \text { to } \\
\text { consolidate radiological surface soil contamination. As } \\
\text { discussed in Section } 2.2 .7 \text {, these windrows may have been } \\
\text { removed, but there is a potential that the contamination } \\
\text { may have been mixed in the shallow subsurface due to } \\
\text { subsequent nuclear testing in the area." }\end{array}$} & \\
\hline $\begin{array}{l}\text { 8.) Section } 2.5, \\
\text { Pages } 21 \text { and } 22, \\
\text { Figures } 2-3 \text { and } 2- \\
4\end{array}$ & Suggested & $\begin{array}{l}\text { a) Suggest add release locations from Figure } 1-1 \text {, which } \\
\text { would also clarify the discussion Section } 2.5 .1 ; \text { b) to } \\
\text { facilitate comparison with other rad survey figures, suggest } \\
\text { add posting boundaries as shown in Figures } 2-6,2-7 \text {, and } \\
\text { elsewhere. }\end{array}$ & \multicolumn{3}{|c|}{$\begin{array}{l}\text { The release locations and posting boundaries were added } \\
\text { to Figures } 2-3 \text { and } 2-4 \text {. }\end{array}$} & \\
\hline
\end{tabular}




\section{Nevada Environmental Management Operations Activity DOCUMENT REVIEW SHEET}

\begin{tabular}{|c|c|c|c|c|c|c|}
\hline \multicolumn{2}{|c|}{ 1. Document Title/Number: } & \multicolumn{2}{|c|}{$\begin{array}{l}\text { Draft Corrective Action Investigatin Plan for Corrective Action Unit 568: Area } 3 \\
\text { Plutonium Dispersion Sites, Nevada National Security Site, Nevada }\end{array}$} & 2. Document Date: & \multicolumn{2}{|l|}{$12 / 4 / 2013$} \\
\hline \multicolumn{2}{|l|}{ 3. Revision Number: } & 0 & & 4. Originator/Organization: & \multicolumn{2}{|l|}{ Navarro-INTERA } \\
\hline \multicolumn{2}{|c|}{$\begin{array}{l}\text { 5. Responsible NNSA/NSO Activity } \\
\text { Lead: }\end{array}$} & Tiffany A. Lantow & & 6. Date Comments Due: & \multicolumn{2}{|l|}{$1 / 3 / 2014$} \\
\hline \multicolumn{2}{|c|}{ 7. Review Criteria: } & Full & & & & \\
\hline \multicolumn{2}{|c|}{ 8. Reviewer/Organization/Phone No: } & o: Jeff MacDougall / Scott Page, NDEP, 486-2850 - ext. 233 and 2 & & 9. Reviewer's Signature: & & \\
\hline $\begin{array}{l}\text { 10. Comment } \\
\text { Number/Location }\end{array}$ & 11. Type* & 12. Comment & \multicolumn{3}{|c|}{ 13. Comment Response } & 14. Accept \\
\hline $\begin{array}{l}\text { 9.) Section } 2.5 \text {, } \\
\text { Page 22, Figure } \\
\text { 2-4 }\end{array}$ & & $\begin{array}{l}\text { Legend upper right: the legend and figure are unclear: a) } \\
\text { top and second blocks appear to show negative values } \\
\text { at }-190 \mathrm{cps} ; \mathrm{b} \text { ) second block is not a range but a single } \\
\text { count } 190 \mathrm{cps} \text {; does AMS have spectral resolution of } 1 \mathrm{cps} \\
\text { over this extensive area? }\end{array}$ & \multicolumn{3}{|c|}{$\begin{array}{l}\text { A paragraph was added to the end of Section } 2.5 .1 \text { stating, } \\
\text { "Note that the data reported in Figure } 2-4 \text { for americium are } \\
\text { the values provided by the Remote Sensing Laboratory. } \\
\text { The algorithm used by the Remote Sensing Laboratory in } \\
\text { the calculation of americium response from the gamma } \\
\text { flyover radiation survey data involves calculating base } \\
\text { values that are partially dependent upon the statistical } \\
\text { uncertainty. When the base values are subtracted from the } \\
\text { survey data, this method sometimes results in negative } \\
\text { values for the americium response. Common convention in } \\
\text { reporting radiation survey results dictates that the negative } \\
\text { numbers be reported because information is lost when the } \\
\text { numbers are truncated to zero." }\end{array}$} & \\
\hline $\begin{array}{l}\text { 10.) Section 2.5, } \\
\text { Page 24, 3rd } \\
\text { Paragraph }\end{array}$ & Mandatory & $\begin{array}{l}\text { 2nd sentence: says RIDP data were "extrapolated"; } \\
\text { however, Section } 2.5 .2 \text { says measurements were made by } \\
\text { in-situ gamma spectroscopy and limited soil sampling, } \\
\text { Figure 2-5 seems to bear this out. Clarify in document. }\end{array}$ & $\begin{array}{l}\text { Beginning wit } \\
\text { edited to read } \\
\text { samples were } \\
\text { isotopes. Bas } \\
\text { spectroscopy } \\
\text { Am-241 were } \\
\text { Am-241 inver } \\
\text { scope of CAL }\end{array}$ & $\begin{array}{l}\text { e second sentence, the par } \\
\text { tt some of these in situ loca } \\
\text { llected and analyzed for plu } \\
\text { on these soil sample and ga } \\
\text { ults, ratios of plutonium (Pu } \\
\text { ed to infer plutonium inventc } \\
\text { ies. These plutonium values } \\
8 \text { are shown on Figure } 2-5 \text {. }\end{array}$ & $\begin{array}{l}\text { agraph was } \\
\text { tions, soil } \\
\text { itonium } \\
\text { amma } \\
\text { )- } 239 / 240 \text { to } \\
\text { ories from the } \\
\text { s within the } \\
\text {.." }\end{array}$ & \\
\hline
\end{tabular}




\section{Nevada Environmental Management Operations Activity DOCUMENT REVIEW SHEET}

\begin{tabular}{|c|c|c|c|c|c|c|}
\hline \multicolumn{2}{|c|}{ 1. Document Title/Number: } & \multicolumn{2}{|c|}{$\begin{array}{l}\text { Draft Corrective Action Investigatin Plan for Corrective Action Unit 568: Area } 3 \\
\text { Plutonium Dispersion Sites, Nevada National Security Site, Nevada }\end{array}$} & 2. Document Date: & \multicolumn{2}{|l|}{$12 / 4 / 2013$} \\
\hline \multicolumn{2}{|l|}{ 3. Revision Number: } & 0 & & 4. Originator/Organization: & \multicolumn{2}{|l|}{ Navarro-INTERA } \\
\hline \multicolumn{2}{|c|}{$\begin{array}{l}\text { 5. Responsible NNSA/NSO Activity } \\
\text { Lead: }\end{array}$} & \multicolumn{2}{|l|}{ Tiffany A. Lantow } & 6. Date Comments Due: & \multicolumn{2}{|l|}{$1 / 3 / 2014$} \\
\hline \multicolumn{2}{|l|}{ 7. Review Criteria: } & \multicolumn{2}{|l|}{ Full } & & & \\
\hline \multicolumn{2}{|c|}{ 8. Reviewer/Organization/Phone No: } & \multicolumn{2}{|l|}{ Jeff MacDougall / Scott Page, NDEP, 486-2850 - ext. 233 and 237} & 9. Reviewer's Signature: & & \\
\hline $\begin{array}{l}\text { 10. Comment } \\
\text { Number/Location }\end{array}$ & 11. Type* & 12. Comment & \multicolumn{3}{|c|}{ 13. Comment Response } & 14. Accept \\
\hline \begin{tabular}{l|} 
11.) Section \\
2.5.2, Page 25, \\
1st Paragraph
\end{tabular} & Suggested & $\begin{array}{l}\text { Expand upon how RIDP/NAEG data are expected support } \\
\text { CSM and guide field investigations. }\end{array}$ & \multicolumn{3}{|c|}{$\begin{array}{l}\text { The sixth sentence in the paragraph was edited and a } \\
\text { sentence was added following the sixth sentence. They } \\
\text { read, "...but provide information to support conceptual } \\
\text { models. These data support the CSM assumptions that } \\
\text { contamination levels are greatest at release locations and } \\
\text { generally decrease with distance from the release } \\
\text { locations." }\end{array}$} & \\
\hline $\begin{array}{l}\text { 12.) Section } \\
2.5 .2 \text {, Page } 25 \text {, } \\
\text { 1st Paragraph }\end{array}$ & Mandatory & $\begin{array}{l}\text { 5th sentence: clarify why RIDP does not have "sufficient } \\
\text { resolution" for biasing sampling when Figure } 2-5 \text { appears to } \\
\text { show relatively high spatial accuracy, resolution, } \\
\text { representative distribution. }\end{array}$ & \multicolumn{3}{|c|}{$\begin{array}{l}\text { The fifth sentence was edited and reads, "...sample } \\
\text { locations with CAU } 568 \text { because RIDP data points are } \\
\text { typically } 400 \text { to } 3,000 \mathrm{ft} \text { apart, and no data are available for } \\
\text { locations between the measured points." }\end{array}$} & \\
\hline $\begin{array}{l}\text { 13.) Section } \\
\text { 2.5.3, Page 25, } \\
\text { 1st Paragraph }\end{array}$ & Mandatory & 6th sentence: clarify "plume areas". & \multicolumn{3}{|c|}{$\begin{array}{l}\text { The fifth sentence was edited and reads, "TRSs were } \\
\text { primarily completed within the areas of radioactivity above } \\
\text { background as identified by the } 2012 \text { aerial radiological } \\
\text { survey (Stampahar, 2012)." }\end{array}$} & \\
\hline $\begin{array}{l}\text { 14.) Section } \\
\text { 2.5.3, Page } 25 \text {, } \\
\text { 1st Paragraph }\end{array}$ & Suggested & $\begin{array}{l}\text { When aerial or terrestrial rad survey data are presented in a } \\
\text { figure, suggest they be accompanied by a sentence or two } \\
\text { of non-appendix interpretation and explanation; i.e., Figure } \\
2-6, \text { "nearly the entire surveyed area showed count data at } \\
\text { or near background..." }\end{array}$ & \multicolumn{3}{|c|}{$\begin{array}{l}\text { In Section 2.5.3, following the callout for Figures 2-6 and } \\
\text { 2-7, the following sentences were added: } \\
\text { "For the PRM-470 TRS, nearly the entire surveyed area } \\
\text { showed count data at or near background. For the FIDLER } \\
\text { TRS, results of the surveyed area were consistent with the } \\
\text { americium aerial radiological survey (Figure 2-4) but } \\
\text { showed a higher resolution." }\end{array}$} & \\
\hline
\end{tabular}




\section{Nevada Environmental Management Operations Activity DOCUMENT REVIEW SHEET}

\begin{tabular}{|c|c|c|c|c|c|c|}
\hline \multicolumn{2}{|c|}{ 1. Document Title/Number: } & \multicolumn{2}{|c|}{$\begin{array}{l}\text { Draft Corrective Action Investigatin Plan for Corrective Action Unit 568: Area } 3 \\
\text { Plutonium Dispersion Sites, Nevada National Security Site, Nevada }\end{array}$} & 2. Document Date: & \multicolumn{2}{|l|}{$12 / 4 / 2013$} \\
\hline \multicolumn{2}{|l|}{ 3. Revision Number: } & \multicolumn{2}{|l|}{0} & 4. Originator/Organization: & \multicolumn{2}{|l|}{ Navarro-INTERA } \\
\hline \multicolumn{2}{|c|}{$\begin{array}{l}\text { 5. Responsible NNSA/NSO Activity } \\
\text { Lead: }\end{array}$} & \multicolumn{2}{|l|}{ Tiffany A. Lantow } & 6. Date Comments Due: & \multicolumn{2}{|l|}{$1 / 3 / 2014$} \\
\hline \multicolumn{2}{|l|}{ 7. Review Criteria: } & \multicolumn{2}{|l|}{ Full } & & & \\
\hline \multicolumn{2}{|c|}{ 8. Reviewer/Organization/Phone No: } & \begin{tabular}{l|l} 
: Jeff MacDougall / Scott Page, NDEP, 486-2850 - ext. 233 and 23 \\
\end{tabular} & & 9. Reviewer's Signature: & & \\
\hline $\begin{array}{l}\text { 10. Comment } \\
\text { Number/Location }\end{array}$ & 11. Type* & 12. Comment & \multicolumn{3}{|c|}{ 13. Comment Response } & 14. Accept \\
\hline $\begin{array}{l}\text { 15.) Section } 2.5 \text {, } \\
\text { Page } 26 \text {, Figure } \\
2-5\end{array}$ & Suggested & $\begin{array}{l}\text { To facilitate comparison with other rad survey figures, } \\
\text { suggest add posting boundaries as shown in Figures } 2-6 \\
\text { and 2-7. }\end{array}$ & \multicolumn{3}{|c|}{ The posting boundaries were added to Figure $2-5$. } & \\
\hline $\begin{array}{l}\text { 16.) Section } \\
\text { 3.1.1, Page } 30 \\
\text { 1st Paragraph }\end{array}$ & Mandatory & Update reference to: DOE, 2013a for land use zone. & \multicolumn{3}{|c|}{$\begin{array}{l}\text { Until the Record of Decision is accepted for the } 2013 \\
\text { SWEIS, the } 2013 \text { SWEIS is not approved to be referenced } \\
\text { in documents. Therefore, the reference to the land-use } \\
\text { scenarios in Section } 3.1 .1 \text { has been changed to the } \\
\text { currently approved EIS (DOE/NV, 1996). }\end{array}$} & \\
\hline $\begin{array}{l}\text { 17.) Section } \\
\text { 3.1.2, Page } 32 \text {, } \\
\text { 1st Paragraph }\end{array}$ & Suggested & $\begin{array}{l}\text { 2nd sentence suggest modify: "...to fix "chemical" and/or } \\
\text { "radiological", if either or both are suspected. }\end{array}$ & \multicolumn{3}{|c|}{$\begin{array}{l}\text { The last sentence in Section } 3.1 .2 \text { has been edited and } \\
\text { reads, "...windrows to fix radiological contamination..." }\end{array}$} & \\
\hline $\begin{array}{l}\text { 18.) Section } 5.0, \\
\text { Page 52, 3rd } \\
\text { Paragraph }\end{array}$ & Suggested & $\begin{array}{l}\text { Insert "RCRA" before phrase, "listed hazardous wastes"; } \\
\text { 2nd sentence suggest rewrite, "...however, RCRA- } \\
\text { characteristic wastes may be generated and will be } \\
\text { managed and disposed of accordingly." }\end{array}$ & \multicolumn{3}{|c|}{$\begin{array}{l}\text { The third paragraph in Section } 5.0 \text { has been updated and } \\
\text { reads, "Chemicals were not known to be used or present at } \\
\text { this CAU in a manner that would generate RCRA-listed } \\
\text { hazardous waste; therefore, wastes will be characterized } \\
\text { based on their chemical characteristics. If RCRA- } \\
\text { characteristic wastes are generated, they will be managed } \\
\text { and disposed of in accordance with applicable waste } \\
\text { requirements." }\end{array}$} & \\
\hline $\begin{array}{l}\text { 19.) Section } 5.0, \\
\text { Page 53, 1st } \\
\text { Paragraph }\end{array}$ & Mandatory & \begin{tabular}{|l|} 
Insert responsible organizational element (N-I, D.O.E., etc.) \\
before "Environmental Compliance and Health and Safety".
\end{tabular} & \multicolumn{3}{|c|}{$\begin{array}{l}\text { The sentence was edited and reads, "To limit unnecessary } \\
\text { generation of hazardous or mixed waste, hazardous } \\
\text { materials will not be used during the CAI." }\end{array}$} & \\
\hline
\end{tabular}




\section{Nevada Environmental Management Operations Activity DOCUMENT REVIEW SHEET}

\begin{tabular}{|c|c|c|c|c|c|c|}
\hline \multicolumn{2}{|c|}{ 1. Document Title/Number: } & \multicolumn{2}{|c|}{$\begin{array}{l}\text { Draft Corrective Action Investigatin Plan for Corrective Action Unit 568: Area } 3 \\
\text { Plutonium Dispersion Sites, Nevada National Security Site, Nevada }\end{array}$} & 2. Document Date: & \multicolumn{2}{|l|}{$12 / 4 / 2013$} \\
\hline \multicolumn{2}{|l|}{ 3. Revision Number: } & 0 & & 4. Originator/Organization: & \multicolumn{2}{|l|}{ Navarro-INTERA } \\
\hline \multicolumn{2}{|c|}{$\begin{array}{l}\text { 5. Responsible NNSA/NSO Activity } \\
\text { Lead: }\end{array}$} & \multicolumn{2}{|l|}{ Tiffany A. Lantow } & 6. Date Comments Due: & \multicolumn{2}{|l|}{$1 / 3 / 2014$} \\
\hline \multicolumn{2}{|c|}{ 7. Review Criteria: } & \multicolumn{2}{|l|}{ Full } & & & \\
\hline \multicolumn{2}{|c|}{ 8. Reviewer/Organization/Phone No: } & \multicolumn{2}{|l|}{ Jeff MacDougall / Scott Page, NDEP, 486-2850 - ext. 233 and 237} & 9. Reviewer's Signature: & & \\
\hline $\begin{array}{l}\text { 10. Comment } \\
\text { Number/Location }\end{array}$ & 11. Type* & 12. Comment & \multicolumn{3}{|c|}{ 13. Comment Response } & 14. Accept \\
\hline $\begin{array}{l}\text { 20.) Section } \\
\text { 5.3.2, Page } 53, \\
\text { 1st Paragraph }\end{array}$ & Mandatory & $\begin{array}{l}\text { Clarify: are satellite accumulation areas anticipated at CAU } \\
568 ?\end{array}$ & \multicolumn{3}{|c|}{$\begin{array}{l}\text { A sentence was added to the end of Section } 5.3 .2 \text { which } \\
\text { reads, "It is anticipated that a satellite accumulation area } \\
\text { will be established due to the small volumes of lead- } \\
\text { contaminated items (i.e., lead-acid batteries) present at the } \\
\text { site." }\end{array}$} & \\
\hline $\begin{array}{l}\text { 21.) Section } \\
\text { A.2.2.6, Page A- } \\
\text { 20, 1st Paragraph }\end{array}$ & Mandatory & $\begin{array}{l}\text { 3rd sentence: update reference to: DOE, 2013a for land } \\
\text { use zone. }\end{array}$ & \multicolumn{3}{|c|}{$\begin{array}{l}\text { Until the Record of Decision is accepted for the } 2013 \\
\text { SWEIS, the } 2013 \text { SWEIS is not approved to be referenced } \\
\text { in documents. Therefore, the reference to the land-use } \\
\text { scenarios in Section A.2.2.6 has been left as the currently } \\
\text { approved EIS (DOE/NV, 1996). }\end{array}$} & \\
\hline 22.) General & Suggested & $\begin{array}{l}\text { Additional technical and editorial comments were received } \\
\text { and incoroporated into the document. }\end{array}$ & \multicolumn{3}{|c|}{$\begin{array}{l}\text { Technical changes include: } \\
\text { 1. Page } 11 \text {, Section } 2.0,1 \text { st sentence: The sentence was } \\
\text { edited as follows: "CAU } 568 \text { comprises } 6 \text { CASs located } \\
\text { within Area } 3 \text { of the NNSS. The investigation will also } \\
\text { address potential surface contamination associated with } 20 \\
\text { documented releases (venting) from underground testing in } \\
\text { the vicinity of the CAU } 568 \text { CASs." } \\
\text { 2. Because the current SWEIS is not complete and } \\
\text { approved by HQ, all references to the current SWEIS were } \\
\text { changed to the } 1996 \text { EIS (DOE/NV, 1996). }\end{array}$} & \\
\hline
\end{tabular}




\title{
Library Distribution List
}

\author{
U.S. Department of Energy \\ Office of Scientific and Technical Information \\ P.O. Box 62 \\ Oak Ridge, TN 37831-0062 \\ Southern Nevada Public Reading Facility \\ c/o Nuclear Testing Archive \\ P.O. Box 98521, M/S 400 \\ Las Vegas, NV 89193-8521 \\ Manager, Northern Nevada FFACO \\ Public Reading Facility \\ c/o Nevada State Library \& Archives \\ 100 N. Stewart Street \\ Carson City, NV 89701-4285
}

$\underline{\text { Copies }}$

1 (Uncontrolled, electronic copy)

2 (Uncontrolled, electronic copies)

1 (Uncontrolled, electronic copy) 